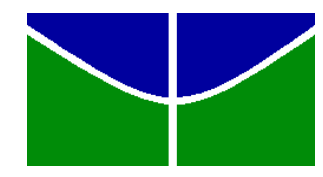

UNIVERSIDADE DE BRASÍLIA

FACULDADE DE EDUCAÇÃO

PROGRAMA DE PÓS-GRADUAÇÃO EM EDUCAÇÃO

KELLY COELHO COSTA BARRETO

AS COTAS NOS CURSOS DE LICENCIATURA PRESENCIAIS DA

UNIVERSIDADE FEDERAL DE GOIÁS: a questão do reconhecimento

Brasília - DF

Abril de 2015 
KELLY COELHO COSTA BARRETO

\section{AS COTAS NOS CURSOS DE LICENCIATURA PRESENCIAIS DA \\ UNIVERSIDADE FEDERAL DE GOIÁS: a questão do reconhecimento}

Dissertação apresentada ao Programa de PósGraduação em Educação (PPGE) da Faculdade de Educação (FE) da Universidade de Brasília/UnB como requisitos para a obtenção do título de Mestre em Educação na linha de pesquisa: Profissão Docente, Currículo e Avaliação, sob orientação da $\operatorname{Prof}^{a} \operatorname{Dr}^{\mathrm{a}}$ Catia Piccolo Viero Devechi. 
Ficha catalográfica elaborada automaticamente, com os dados fornecidos pelo(a) autor(a)

Coelho Costa Barreto, Kelly
AS COTAS NOS CURSOS DE LICENCIATURA PRESENCIAIS
DA UNIVERIDADE FEDERAL DE GOIÁS: a questão do
reconhecimento / Kelly Coelho Costa Barreto;
orientador Catia Piccolo Viero Devechi. -- Brasília,
2015.
106 p.
Dissertação (Mestrado - Mestrado em Educação) --
Universidade de Brasília, 2015.
1. Ações afirmativas. 2. Cotas. 3Reconhecimento.
Licenciaturas . I. Piccolo Viero Devechi, Catia
orient. II. Título




\section{AS COTAS NOS CURSOS DE LICENCIATURA PRESENCIAIS DA UNIVERSIDADE FEDERAL DE GOIÁS REGIONAL GOIÂNIA: a questão do reconhecimento}

Defesa de Dissertação de Mestrado apresentada à seguinte Banca Examinadora:

Profa. Dra. Catia Piccolo Viero Devechi

Orientadora (UnB)

Profa. Dra. Gionara Tauchen
Membro externo (FURG)

Profa. Dra. Kátia Augusta Curado Pinheiro Cordeiro

Membro interno (UnB)

Profa. Dra. Wivian Jany Weller

Membro Suplente (UnB)

Brasília - DF

Abril de 2015 
A minha filha Maria Clara, meu esposo Weslley e minha mãe Maria Dos Reis. 


\section{Agradecimentos}

Primeiramente, a Deus e a Nossa Senhora por sempre iluminar os meus passos me sustentando na fé e na esperança.

Ao meu esposo e companheiro Weslley, o apoio incondicional, a paciência, o amor, a compreensão e, principalmente, a força que transmitia quando as dificuldades se faziam presentes.

A minha filha Maria Clara, que a cada mexida no meu ventre fazia o meu coração bater mais forte nas horas de estudos. O seu nascimento trouxe a razão de todo o meu viver me dando força para concluir o trabalho.

A minha família maravilhosa que sempre esteve ao meu lado dando todo amor e carinho (Mamãe, Kennya e Mônica).

Aos meus colegas de Mestrado em Educação da Universidade de Brasília, pela troca de experiências e conhecimentos.

Em especial aos amigos: Josimara, Wanderson e Sebastião, que nessa caminhada construímos uma amizade verdadeira, vencendo as barreiras e as dificuldades, compartilhando das mesmas alegrias.

Aos primos Ronielton e Annaliza, por todo carinho e ajuda nessa etapa da minha vida.

A uma grande amiga Vanderleida, pelas leituras realizadas em meu trabalho e, principalmente pelo carinho, apoio e palavras de incentivo.

Aos professores do programa de pós-graduação da Faculdade de Educação da UnB, por todo ensinamento, partilha e amizade. Em especial: Catia Piccolo, Cleide Quixadá Viana, José Vieira, Liliane Campos, Carlos Alberto e Lívia Freitas.

À professora Catia Piccolo Viero Devechi, pela amizade, convivência, apoio e ensinamentos, construídos no decorrer das orientações. Sua atuação foi primordial para o desenvolvimento deste trabalho. Um exemplo de pessoa e educadora: meu reconhecimento e admiração.

Aos membros da banca, que através de leitura atenta do trabalho, com as suas sugestões e apontamentos de extrema relevância para a finalização desta pesquisa.

Ao programa de pós-graduação da Faculdade de Educação da UnB, pela oportunidade e apoio com vista a formação profissional mais qualificada. 
À universidade Federal de Goiás, por disponibilizar as informações necessárias para a realização deste trabalho.

À Capes, pela bolsa concedida.

A todos, os meus sinceros agradecimentos. 
(...) a liberdade da autorrealização depende de pressupostos que não estão à disposição do próprio sujeito humano, visto que ele só pode adquiri-la com a ajuda de seu parceiro de interação.

Honneth, 2003 p. 273

Tudo posso naquele que me fortalece

Filipense 4:13 


\section{RESUMO}

Considerando que desde 2009, a Universidade Federal de Goiás (UFG) Regional Goiânia, por meio do programa UFG/Inclui, vem trabalhando com o sistema de cotas, que contempla os alunos provenientes de escola pública, negros, indígenas, surdos e quilombolas, o presente estudo procura compreender como os cursos de licenciatura presenciais da UFG estão apoiando o reconhecimento dos seus alunos que entraram por meio do sistema de cotas. A partir da abordagem hermenêutica, o estudo buscou alcançar os seguintes objetivos específicos: identificar o número de alunos que entraram pelo sistema de cotas ingressos e evadidos das licenciaturas da UFG Regional Goiânia; compreender as estratégias da UFG no reconhecimento das diferenças; analisar como o reconhecimento dentro da universidade pode influenciar na formação docente. Como suporte teórico utilizou-se, principalmente, Honneth (2003), Nóvoa (1992; 1999), Imbernón (2011) e Brzezinski (2002; 2008). Para a produção de dados, aplicou-se, em um primeiro momento, um questionário aos coordenadores dos cursos de licenciatura presenciais e realizou-se a análise dos documentos do programa UFG/Inclui, da legislação e regulamento da UFG. Em um segundo momento, aplicou-se também um questionário aos alunos ingressos pelo sistema de cotas nos cursos de licenciatura presenciais com o intuito de averiguar como os estudantes do sistema de cotas se percebem dentro da universidade no que se refere ao seu reconhecimento diante do outro. Os resultados indicam que a UFG, por meio do programa UFG/Inclui, vem democratizando o acesso à Educação Superior e promovendo ações de permanência. No entanto, este apresenta lacunas como a falta de apoio pedagógico e a insuficiência de bolsas. $\mathrm{O}$ estudo nos permitiu certificar a inativação dos alunos provenientes do sistema de cotas devido ao baixo desenvolvimento nas disciplinas, dificuldade de conciliar estudo e trabalho, reprovação, não efetivação da matrícula, opção por outro curso e problema financeiro. Lembrando que alguns cursos como física, geografia, química, história e pedagogia têm um percentual maior de desistentes. Foi possível também identificar que a questão do reconhecimento é abordada de forma superficial pela instituição, não sendo levadas em conta as particularidades e individualidades dos sujeitos que a integram. Esses fatores refletem de forma negativa na formação dos futuros professores, pois a falta de reconhecimento tem influência na construção da identidade e na autorrealização do profissional docente da área.

Palavras-chave: Ações afirmativas. Cotas. Licenciaturas. Reconhecimento. 


\begin{abstract}
Since 2009, the Federal University of Goiás (UFG) Regional Goiania, through the program UFG/Includes, has been working with the quota system, which includes students from public schools, blacks, indians, deaf and quilombola. This study seeks to understand how the presence degree courses at UFG are supporting the recognition of students who entered through the quota system. From the hermeneutic approach, the study sought to achieve the following specific objectives: to identify the number of students who entered the system of admission and escaped quotas of undergraduate UFG Regional Goiania; understand the strategies of UFG in recognition of the differences, analyze how the recognition within the university can influence in teacher education. The main theoretical supports used were Honneth (2003), Nóvoa (1992; 1999), Imbernon (2011) and Brzezinski (2002; 2008). For the production of data, in the first moment were applied a questionnaire to coordinators of presence's undergraduate and conducted the analysis of documents of program UFG /Includes, legislation and regulation of UFG. In a second step, also applied a questionnaire to students admitted by the quota system in courses of undergraduate, in order to investigate how students perceive theirself within the quota system the university with regard to recognition on the other. The results indicate that the UFG through the program UFG / Includes has democratized the access to higher education and promoted permanence actions. However, this has gaps, such as lack of teaching aids and scholarship. The study allowed us to ensure the inactivation of students from the quota system due to the low development in the disciplines, difficulty of reconciling study and work, failure, not effect the registration, opt for another course and financial problems. Recalling that some courses such as physics, geography, chemistry, history and pedagogy has a higher percentage of dropouts. It was determined that the issue of recognition is covered superficially by the institution, did not take into account the particularities and individualities of the subjects belonging to it. These factors reflect negatively on the training of future teachers, because the lack of recognition has influence on the construction of identity and self-realization of the teaching of area professional.
\end{abstract}

Keywords: Affirmative action. Quotas. Teacher Training. Recognition. 


\section{LISTA DE SIGLAS}

ASCOM Assessoria de Comunicação da UFG

CONSUNI Conselho Universitário

ENCCEJA Exame Nacional para Certificação de Competências de Jovens e Adultos

ENEM Exame Nacional de Ensino Médio

PNAA Programa Nacional de Ações Afirmativas

FUNAI Fundação Nacional do Índio

IBGE Fundação Instituto Brasileiro de Geografia e Estatística

IES Instituto de Educação Superior

INCRA Instituto Nacional de Colonização e Reforma Agrária

INEP Instituto Nacional Anísio Teixeira

MEC Ministério da Educação

ONU Organização das Nações Unidas

PBP Programa de Bolsa Permanência

PROLICEN Programa de Bolsas de Licenciaturas

PROEC Pró-Reitoria de extensão e cultura

PROGRAD Pró-Reitoria de Graduação

PET Programa de Educação Tutorial

PRONERA Programa Nacional de Educação na Reforma Agrária

PROUNI Programa Universidade para todos

REUNI Reestruturação e Expansão das Universidades

SECADI Secretaria de Educação Continuada, Alfabetização, Diversidade e Inclusão

SIC Sistema Eletrônico do Serviço de Informação ao Cidadão

SISU Sistema de Seleção Unificado

UNESCO Organização das Nações Unidas para a Educação, a Ciência e a Cultura

UFG Universidade Federal de Goiás

UERJ Universidade do Estado do Rio de Janeiro

UnB Universidade de Brasília 


\section{LISTA DE FIGURAS}

Figura 1: Sistema de preenchimento da reserva de vagas do processo seletivo 2013/1 Lei 12.711- UFG 


\section{LISTA DE GRÁFICOS}

Gráfico 1: Total de candidatos inscritos no programa UFG/Inclui período de 2009 a 2012.

Gráfico 2: Total de candidatos aprovados no programa UFG/Inclui período de 2009 a 2012

Gráfico3: Quantidade de alunos inscritos na UFG nos cursos de licenciatura de acordo com o gênero- 2011 a 2012

Gráfico 4 Quantidade de alunos inscritos na UFG nos cursos de licenciatura de acordo com o gênero- 2013 a 2014 .36

Gráfico 5: Número de alunos que entraram pelo sistema de cotas evadidos dos cursos de Licenciatura UFG 2009 a 2013 .42

Gráfico 6: Comparativo- Desempenho estudantes de pedagogia 2009-2012 .46

Gráfico 7 Questão 14 (Como é o desenvolvimento do aluno que entram por meio do sistema de cotas no curso?)

Gráfico 8: Questão 15 (Como o Curso vem tentando garantir a permanência dos alunos do sistema de cotas?)

Gráfico:9Questão8Você percebe a sua individualidade reconhecida na universidade? 75

Gráfico 10: Questão 16 (Alguma vez você foi discriminado por ser aluno oriundo do sistema de cotas?) .81

Gráfico11: Questão $17 \quad$ (Você se sente realizado no curso?) .84 


\section{LISTA DE QUADROS}

Quadro 1: Número de alunos ingressantes pelo sistema universal e de cotas nos cursos de licenciatura no Brasil período de 2009 a 2012

Quadro 2: Opção de participação dos estudantes no processo seletivo e a escola proveniente 2011 a2012.

Quadro 3: Opção de participação dos estudantes no processo seletivo e a escola proveniente 2013 a 2014. 33

Quadro 4: Questão 14 (Justificativa). .69

Quadro 5: Questão 15 (Justificativa). .71

Quadro 6 Questão 16 (Como os cursos estão preparando para atender os alunos do sistema de cotas a partir de 2013, considerando a Lei 12.711?).......................................................... 72

Quadro 7: (Qual avaliação você faz do programa UFG/inclui?)......................................... 74

Quadro8: Questão 10 (Para você, o projeto UFG/Inclui influência no acolhimento das

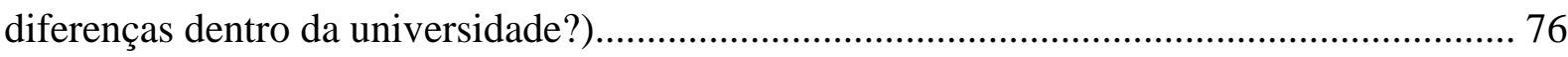

Quadro 9 Questão 11 (Justifique a resposta da pergunta 11?)............................................. 78

Quadro10: Questão12 (Do seu ponto de vista, que ações de assistência estudantil a universidade deve oferecer para que todos os alunos sejam reconhecidos?) 79

Quadro 11: Questão 15 (Você tem dificuldade de se reconhecer como aluno proveniente do sistema de cotas?).

Quadro 12: Questão19 (Quais as dificuldades encontradas em seu processo de formação dentro da UFG?). 85

Quadro 13: Questão 21 (O que você pretende fazer em relação as políticas de inclusão quando estiver na escola?). 86 


\section{LISTA DE TABELAS}

Tabela 1: Renda mensal da família dos alunos que optaram pelo sistema de cotas 20112014

Tabela 2: Renda mensal da família dos alunos que optaram pelo sistema universal 20112014

Tabela 3: Como os estudantes do sistema de cotas pretendem se manter na universidade 2011 a 2014

Tabela 4: O serviço complementar que os estudantes do sistema de cotas preferem que a UFG realize 2011 a 2014

Tabela 5: Forma de preparação dos alunos que optaram pelo sistema de cotas para entrarem na universidade 2011 a 2014.

Tabela 6: Motivação da inativação dos alunos oriundos do sistema de cotas nos cursos de licenciatura da UFG 2009 a 2013 44

Tabela 7: Questão 13 (Quais são as dificuldade do curso no acolhimento dos alunos do sistema de cotas? Se considerar necessário marque mais de uma alternativa?) 68 


\section{SUMÁRIO}

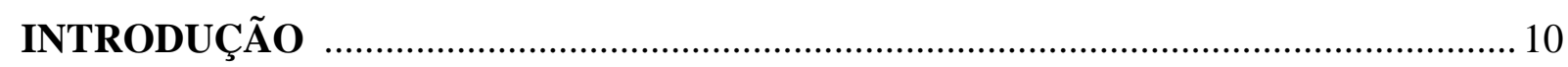

Contexto das políticas afirmativas e o sistema de cotas nas universidades brasileiras ........... 10

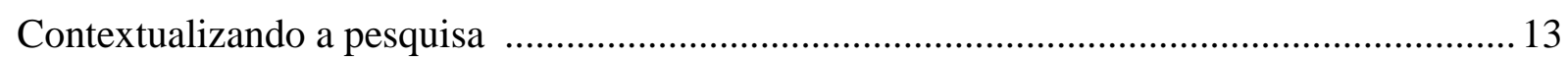

1. AÇÕES DESENVOLVIDAS NA UNIVERSIDADE FEDERAL DE GOIÁS REGIONAL GOIÂNIA E NO PROGRAMA UFG/INCLUI ......................................... 17

2. ALUNOS DAS LICENCIATURAS UFG REGIONAL GOIÂNIA QUE ENTRARAM

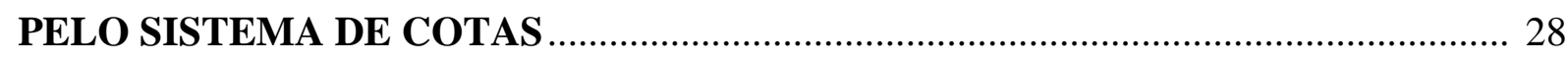

2.1. As cotas nos cursos de licenciaturas das instituições de Educação Superior ..................... 28

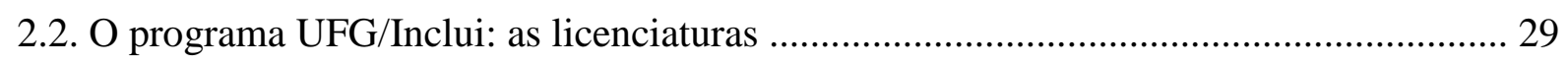

3. A LUTA PELO RECONHECIMENTO E A FORMAÇÃO DE PROFESSORES......48

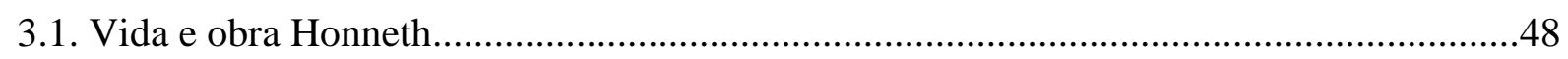

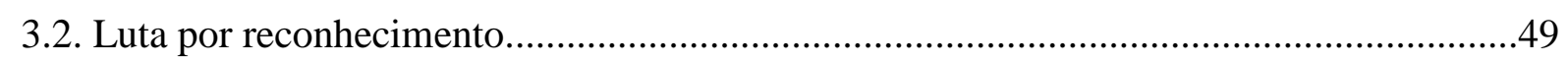

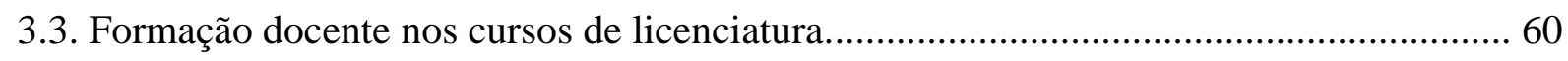

4. PERCEPÇÃO DOS COORDENADORES E DOS ALUNOS DAS LICENCIATURAS QUE ENTRARAM PELO SISTEMA DE COTAS NA UFG REGIONAL GOIÂNIA

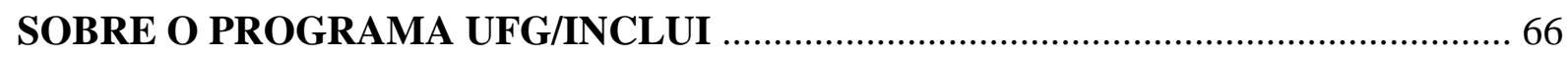

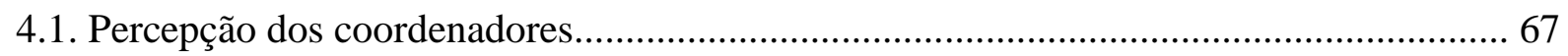

4.2. A percepção dos alunos que entraram pelo sistema de cotas .........................................73

4.3. A importância do reconhecimento do outro na formação profissional docente ............... 88

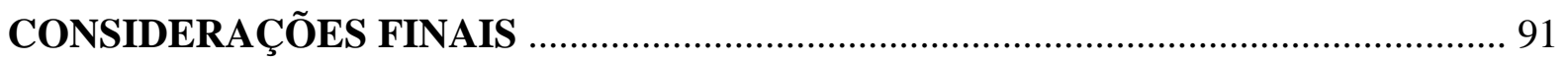

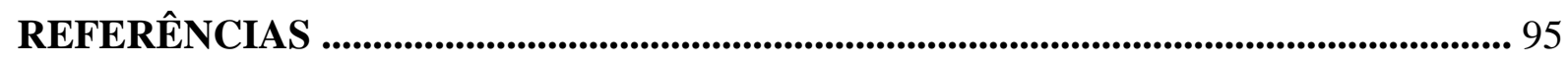




\section{INTRODUÇÃO}

\section{Contexto das políticas afirmativas e o sistema de cotas nas universidades brasileiras:}

Nos últimos anos, as políticas públicas de formação superior têm sido bastante reivindicadas, apresentando às universidades desafios, cada vez maiores, para o acesso e permanência dos que a ela recorrem. A partir de políticas afirmativas, a universidade tem aberto as "portas" para as pessoas em situação de desvantagem socioeconômica e também aos excluídos por suas características raciais e étnicas que, por vários anos, estiveram fora do sistema universitário.

Muitos alunos não conseguem ingressar na universidade devido à desigualdade social, à discriminação e pela forma como a seleção é realizada. Uma das formas adotadas pelas instituições públicas de Educação Superior foi, por anos, e ainda é em algumas instituições, o vestibular. Como frisa Cordeiro (2010), o vestibular tem como propósito selecionar os alunos que se enquadram no perfil que a universidade deseja, desconsiderando os saberes necessários e específicos que contribuem, de maneira significativa, na trajetória acadêmica do estudante e também na obtenção e na construção do conhecimento. Assim, o vestibular acaba por se constituir como forma de sustentar a reprodução social caracterizada pela hierarquia de classes dentro da universidade. Além disso, somente alguns grupos, com boas condições sociais, conseguem ter um desempenho positivo no processo seletivo das instituições de Educação Superior, pois tiveram a oportunidade de estudar em escolas privadas e em cursos preparatórios. Já para os menos favorecidos, uma das poucas opções que restam é o ensino oferecido nas escolas públicas, que, em sua expressiva maioria, é precário e com baixa qualidade.

Desde 1990, o governo brasileiro vem investindo em políticas públicas para os grupos sociais discriminados. O objetivo dessas políticas tem sido promover a justiça e a efetivação do direito à cidadania, por meio de distribuição dos benefícios nas esferas da educação, saúde, moradia, transporte, assistência social, cultura, entre outros. Com o intuito de minimizar a exclusão étnica e social no país, o Estado tem buscado atender às demandas sociais por meio de ações afirmativas.

Gomes (2001, p. 32) define essas ações “como políticas públicas (e privadas) voltadas à concretização do princípio constitucional da igualdade material e à neutralização dos efeitos da discriminação racial, de gênero, de idade, de origem nacional e de compleição 
física". Na sua compreensão, a igualdade deixa de ser simplesmente um princípio jurídico a ser respeitado por todos e passa a ser um objetivo constitucional a ser alcançado pelo Estado e pela sociedade.

As ações afirmativas buscam beneficiar os excluídos de uma sociedade marcada pela desigualdade social, racial e de gênero, intencionando promover mais igualdade (dos direitos civis, culturais, econômicos e políticos). Segundo Gomes (2001), o propósito é provocar mudanças tanto cultural como pedagógica e psicológica, capazes de eliminar a ideia que o povo tem no que se refere à superioridade e à submissão de uma raça em relação à outra e também do homem em relação à mulher.

As ações afirmativas têm o papel de incluir os grupos minoritários que, por muito tempo, foram silenciados e excluídos do meio social. De acordo com Silvério (2005), essas ações não acontecem em um processo simples, são necessários investimentos, recursos e profissionais comprometidos em romper com as atitudes e ideias preconceituosas, tendo como finalidade oferecer um mundo onde as pessoas tenham igualdade de condições e sejam respeitadas.

Zoninsien (2006) pondera que há três objetivos das ações afirmativas: 1) a efetivação de uma sociedade democrática; 2) uma distribuição que favoreça a todos de forma igual; 3) o crescimento econômico. No entanto, para ele, essas ações não acontecem de forma involuntária ou automaticamente, mas requerem a participação da sociedade civil, do capital social e dos grupos excluídos, na busca pela democratização das oportunidades.

Nesse sentido, nota-se que as políticas de ações afirmativas vêm se constituindo nas universidades brasileiras por meio de um processo gradativo de conquistas, discussões e lutas. No decorrer de sua história, aprovou-se uma sucessão de leis, projetos e decretos com o objetivo de eliminar a discriminação. Muitas discussões/ações foram promovidas para que se alcançasse o reconhecimento governamental da necessidade da política de ações afirmativas nas universidades públicas. No ano de 1965, foi aprovada em Nova York a Convenção sobre a Eliminação de todas as formas de Discriminação Racial. Segundo o artigo VII da Convenção, seria tarefa dos Estados-Partes eliminar as formas de discriminação e preconceito, tomar medidas eficientes que proporcionem relações de respeito e amizade entre todos, independentemente de raça, sexo, idioma e etnia, e promover a igualdade, a dignidade, e a liberdade dos indivíduos (CONVENÇÃO ONU, 1965).

O Brasil, desde 1968, é subscritor da Convenção, tendo como propósito pôr fim à discriminação e promover o respeito a todos os cidadãos brasileiros, sem distinção de qualquer natureza, raça, cor ou etnia. Em 1983, foi elaborado no país o projeto de Lei $\mathrm{n}^{\circ}$ 
1.332, que objetivou propor ação compensatória aos negros no que diz respeito às cotas no ensino superior e no mercado de trabalho (BRASIL, 1983).

Entretanto, o grande marco de combate à discriminação no Brasil foi fixado na Constituição de 1988. Segundo o artigo $3^{\circ}$ :

Constituem objetivos fundamentais da República Federativa do Brasil: I construir uma sociedade livre, justa e solidária; II - garantir o desenvolvimento nacional; III - erradicar a pobreza e a marginalização e reduzir as desigualdades sociais e regionais; IV - promover o bem de todos, sem preconceitos de origem, raça, sexo, cor, idade e quaisquer outras formas de discriminação (BRASIL, 1988).

Anos depois, em setembro de 2001, aconteceu na cidade de Durban, na África do Sul, a III Conferência Mundial de Combate ao Racismo, Discriminação Racial, Xenofobia e Intolerância Correlata, que teve responsibilizaram-se os Estados pelo compromisso em corrigir as desigualdades sociais. Como resultado, os Estados buscaram por meio de políticas públicas colocarem um fim à exclusão social, procurando reconhecer e corrigir toda forma de discriminação. Na Conferência, a compreensão foi que a educação é o instrumento primordial para as mudanças de gestos e comportamentos referentes à discriminação em todos os sentidos, podendo promover a democracia, a justiça e a igualdade (CONFERÊNCIA DE DURBAN, 2001).

O governo federal brasileiro no ano de 2002, pelo decreto $n^{\circ} 4.228$, criou o Programa Nacional de Ações Afirmativas (PNAA), que visava à ampliação dos espaços dos grupos discriminados para que pudessem exercer a cidadania, garantindo os direitos humanos e eliminando as desigualdades de gênero, raça e as diferentes formas de preconceito direcionadas às pessoas portadoras de deficiência. Naquele ano, juntamente com a Lei $\mathrm{n}^{\circ}$ 10.558, foi criado o Programa Diversidade na Universidade que implementou e avaliou meios para a promoção do acesso ao ensino superior às pessoas excluídas socialmente, dando ênfase à população negra e indígena (BRASIL, 2002). Um ano depois, com a Lei no 10.639/2003, tornou-se obrigatório o ensino de História e Cultura Afro-brasileira nos currículos do Ensino Médio de escolas públicas e particulares.

Pode-se dizer que, a partir da década de 1990, com a democratização da universidade, passou-se a se discutir, cada vez mais, sobre ações afirmativas e o sistema de cotas. O Programa Universidade Para Todos (Prouni) foi um dos primeiros passos das ações afirmativas na Educação Superior. Ele foi criado pelo governo federal, pela da Lei n ${ }^{\circ}$ 11.096, em 13 de janeiro de 2005, oferecendo bolsas de estudos integrais e parciais em instituições privadas (BRASIL, 2005). 
Em 2012, foi sancionada a Lei $n^{\circ} 12.711$ que garantiu a reserva de 50\% das vagas nas instituições federais de Educação Superior e nas instituições federais de educação, ciência e tecnologia a alunos provenientes do ensino médio público, em cursos regulares ou da educação de jovens e adultos. Essa reserva deve ser subdividida da seguinte forma: metade das vagas será destinada a alunos de escola pública com renda familiar igual ou inferior a um salário mínimo e meio per capita e a outra metade a alunos de escolas públicas com renda familiar superior a um salário mínimo e meio per capita. Nos dois casos deverá existir uma reserva de vagas para os alunos autodeclarados pretos, pardos e indígenas, em proporção, no mínimo, igual à de pretos, pardos e indígenas, de acordo com a população da unidade da Federação onde está localizada a instituição, tendo como referência os levantamentos estatísticos do Instituto Brasileiro de Geografia e Estatística (IBGE). Os demais 50\% das vagas permanecem para ampla concorrência (BRASIL, 2012).

De acordo com a referida Lei, o programa será avaliado pelo Ministério da Educação e também pela Secretaria Especial de Políticas, sendo também ouvida a FUNAI. As Universidades terão o prazo máximo de quatro anos, a partir da data da publicação desta lei, para o cumprimento integral do disposto nessa lei (BRASIL, 2012).

Percebe-se que as ações afirmativas têm se ampliado nos espaços sociais, políticos e educacionais, de forma muito gradativa. Diante desse fato, vários pesquisadores como: Jacques Velloso, Letícia Sousa, Écio Portes, Maria Cristina Santos, entre outros têm estudado esses temas com o intuito de colaborar para que ocorra a efetivação da inclusão dos grupos historicamente excluídos do sistema social. Mesmo com os avanços das leis, produções e publicações sobre o assunto, ainda existem pontos relevantes a serem estudados para que a Educação Superior possa se concretizar, de fato, como um direito de todos.

\section{Contextualizando a pesquisa}

Considerando a importância do tema e as práticas que têm sido implementadas com o objetivo de atender ao novo dispositivo legal, buscamos compreender as estratégias de reconhecimento promovidas pela Universidade Federal de Goiás (UFG) ${ }^{1}$ Regional Goiânia e pelos seus cursos de licenciatura presenciais. Perguntamos: como os cursos de licenciatura

\footnotetext{
${ }^{1}$ De acordo com o Estatuto do dia 29 de novembro de 2013, no seu artigo 13, a UFG é estruturada em múltiplos câmpus, organizados administrativamente em regionais. Regional é considerado um espaço administrativo localizado em uma determinada região do estado de Goiás, composta com estrutura acadêmico-administrativa, que desenvolve ensino, pesquisa e extensão. A UFG conta com as seguintes regionais: Regional Goiânia, Regional Catalão, Regional Jataí, Regional Goiás e Regional Cidade Ocidental. Assim usaremos a nomenclatura regional e não câmpus.
} 
presenciais da UFG estão apoiando o reconhecimento dos seus alunos ${ }^{2}$ que entraram por meio do sistema de cotas?

A opção pela UFG Regional Goiânia se justifica pelo fato de a instituição receber os alunos oriundos do sistema de cotas desde 2008, por meio do programa UFG/Inclui, que visa ao acesso e à permanência nos cursos de graduação oferecidos pela instituição. $O$ programa tem a finalidade de promover a igualdade e de combater atos discriminatórios, procurando contribuir com o desenvolvimento acadêmico dos alunos que entraram pelo sistema de cotas. Essas ações serão apresentadas no Capítulo 1.

Para responder ao problema proposto, foram estabelecidos os seguintes objetivos específicos: identificar o número de alunos, que entraram pelo sistema de cotas, ingressos e evadidos das licenciaturas da UFG Regional Goiânia; compreender as estratégias da UFG no reconhecimento das diferenças; e, por último, analisar como o reconhecimento dentro da universidade pode influenciar na formação docente.

Buscamos discutir o reconhecimento do aluno das licenciaturas proveniente do sistema de cotas na universidade a partir da discussão sobre a luta pelo reconhecimento de Axel Honneth (2003). O autor defende que o indivíduo só é reconhecido quando o outro o reconhece em sua singularidade e originalidade. Consequentemente, a cada nova etapa, o indivíduo vai conhecendo as dimensões de sua identidade, ocorrendo novas lutas por reconhecimento em um espaço dialógico. Segundo Honneth:

[...] os indivíduos se constituem como pessoas unicamente porque, da perspectiva dos outros que assentem ou encorajam, aprendem a se referir a si mesmos como seres a que cabem determinadas propriedades e capacidades. A extensão dessas propriedades e, por conseguinte, o grau da autorrealização positiva crescem com cada nova forma de reconhecimento, a qual o indivíduo pode referir a si mesmo como sujeito: desse modo, está inscrita na experiência do amor a possibilidade da autoconfiança, na experiência do reconhecimento jurídico, a do autorrespeito e, por fim, na experiência da solidariedade a da autoestima. (HONNETH, 2003, p. 272)

Portanto, os indivíduos e os grupos sociais se autorrealizarão a partir do momento em que forem reconhecidos intersubjetivamente nas esferas do amor, das relações jurídicas e da solidariedade social. Assim, quanto mais reconhecimento por parte do outro, maior será o grau da autorrealização. A partir do momento que as potencialidades e as capacidades são reconhecidas, os estudantes desenvolvem a sua autonomia e constroem a sua identidade.

\footnotetext{
${ }^{2}$ Não usaremos o termo cotista para nos referirmos aos alunos, pois entendemos que cotista não é uma identidade.
} 
Metodologicamente utilizamos, nesta pesquisa, a hermenêutica reconstrutiva, sendo esta "a arte de compreender um sentido linguisticamente comunicável e, no caso de comunicações perturbadas, torná-lo inteligível” (HABERMAS, 1987, p. 26). Essa abordagem sustenta a necessidade do entendimento com o outro no tratamento dos problemas. Nesse sentido, trataremos de oferecer não uma verdade sobre o assunto, mas apenas uma pretensão de validade a ser legitimada no discurso. Entendemos que apenas no discurso é possível validar ou não as pretensões de validades alcançadas. Segundo Devechi e Trevisan (2010, p. 155), essa perspectiva: "permite repensar o conhecimento a partir do processo de busca do entendimento mútuo, no qual pretensões de validades são reconhecidas intersubjetivamente". Ou seja, busca-se construir uma relação discursiva em que a opinião do outro é fundamental para validação das pretensões de validades apresentadas.

Para a realização desta pesquisa, de ínicio, fizemos um levantamento bibliográfico sobre as temáticas referentes às cotas, ações afirmativas, reconhecimento do outro, políticas públicas, bem como um levantamento documental do programa UFG/Inclui, da legislação e regulamento da UFG. Além do levantamento bibliográfico e documental, aplicamos um questionário com perguntas fechadas e abertas aos coordenadores dos cursos de licenciatura presenciais da UFG Regional Goiânia. Os cursos foram: artes cênicas, artes visuais, ciências biológicas, ciências sociais, educação física, filosofia, física, geografia, história, letras, licenciatura intercultural indígena, letras-libras, matemática, música, educação musical, pedagogia, psicologia e química. O objetivo do questionário foi identificar e analisar a importância do reconhecimento dos alunos provenientes do sistema de cotas nos cursos de licenciatura. Em um segundo momento, foi aplicado outro questionário com perguntas fechadas e abertas aos estudantes do sistema de cotas dos cursos de licenciaturas presenciais para compreender como eles se percebem dentro da universidade no que se refere ao seu reconhecimento diante do outro.

Tanto o questionário para os coordenadores quanto para os alunos foram elaborados no programa encuestafácil e enviado via e-mail, não sendo revelado o nome dos participantes. Os e-mails foram enviados individualmente, não permitindo que os participantes tivessem acesso ao e-mail e à resposta do outro. Além disso, cada coordenador que aceitou responder o questionário assinou um termo de consentimento livre e esclarecido. Em relação aos estudantes no próprio sistema do encuestafácil inserimos uma carta apresentando a pesquisa e juntamente o termo de consentimento livre e esclarecido. Na escrita do trabalho, buscamos preservar a identidade dos coordenadores e alunos, não os expondo de forma alguma. 
A dissertação está estruturada em quatro capítulos. No primeiro capítulo são apresentadas as ações/estratégias de permanência desenvolvidas na UFG e no programa UFG/Inclui. No segundo capítulo, explicita-se o perfil dos alunos da licenciatura que entraram por meio do sistema de cotas da UFG. No terceiro capítulo, apresenta-se uma reflexão sobre a teoria do reconhecimento de Axel Honneth (2003) e a formação de professores. No quarto capítulo, discute-se como o reconhecimento dos alunos das licenciaturas que entram pelo sistema de cotas pode influenciar na formação docente. 


\section{AÇÕES DESENVOLVIDAS NA UNIVERSIDADE FEDERAL DE GOIÁS REGIONAL GOIÂNIA E NO PROGRAMA UFG/INCLUI}

A UFG foi criada pelo decreto 3.838-c, em 14 de dezembro de 1960, com a reunião de cinco escolas existentes na época na cidade de Goiânia, como a Faculdade de Medicina, a Faculdade de Farmácia e Odontologia, o Conservatório de Música, a Escola de Engenharia e a Faculdade de Direito. As primeiras faculdades foram instaladas no Câmpus Praça Universitária (Colemar Natal e Silva). Posteriormente, com a expansão dos cursos e outras faculdades, foi criado o Câmpus Samambaia. Além desses câmpus foram criados outros nas cidades de Jatai, Catalão e Cidade de Goiás. Os câmpus na cidade de Goiânia são compostos por várias Unidades Acadêmicas, denominadas Institutos, Faculdades ou Escolas, Com os cursos de graduação oferecem diversas formações profissionais e acadêmicas (Plano de Desenvolvimento Institucional, 2011/15). A instituição tem como compromisso a qualidade do ensino, da pesquisa e da extensão, visando a:

produzir, sistematizar e transmitir conhecimentos, ampliar e aprofundar a formação do ser humano para o exercício profissional, a reflexão crítica, a solidariedade nacional e internacional, com o objetivo de contribuir para a existência de uma sociedade mais justa, em que os cidadãos se empenhem na busca de soluções democráticas para os problemas nacionais (UFG. 2011/15 p. 13).

Desde a sua criação, a UFG tem como finalidade assegurar formação profissional e acadêmica, entrelaçando o ensino, a pesquisa e a extensão, garantindo aos alunos a ampliação do conhecimento, a reflexão crítica e a formação humana e profissional. O propósito é garantir aos estudantes a possibilidade de promover soluções para os problemas existentes em nossa sociedade, contribuindo com o desenvolvimento social e econômico.

Desse modo, a universidade vem buscando formas de proporcionar alargamento na qualidade do ensino e expansão no número de vagas, modificando as suas ações no que diz respeito ao ensino e à estrutura física da instituição, caracterizando-se como um espaço de formação e de produção do conhecimento. Em 1960, a instituição desenvolvia somente atividade de ensino, já em 1970, surgiu a necessidade de articular ensino, pesquisa e extensão, sendo que, somente em 1990, houve uma consolidação mais significativa dessa articulação. Neste mesmo ano, a universidade passou por um processo de expansão. No conjunto das mudanças que a expansão propiciou, podemos destacar a adoção do regime seriado em 1984, passando as matrículas anuais a serem em bloco fixo de disciplinas. Em 1997, foi criado um novo estatuto para a universidade. No ano de 2002, as disciplinas passaram a ser de livre escolha do aluno, dando a oportunidade de uma formação mais ampla de acordo com seus 
interesses. Em 2006, a universidade sofreu alterações na organização física e acadêmica dos câmpus de Catalão e de Jataí e no ano de 2008, foi implementado o Programa de Reestruturação e Expansão das Universidades Federais (REUNI) (UFG. Plano de Desenvolvimento Institucional, 2011/15).

Além dessas mudanças, a UFG, com o objetivo de abarcar uma gama maior de estudantes que, por muitos anos, foram excluídos da Educação Superior e proporcionar a sua permanência na universidade, vem, desde 1994, investindo em ações afirmativas, por meio da adesão ao Programa de Educação Tutorial ${ }^{3}$ (PET) institucionalizado pelo Ministério da Educação (MEC). Houve também a vinculação da universidade ao Programa de Bolsas de Licenciaturas (Prolicen) desenvolvida pelo Ministério da Educação (MEC)/ Secretaria de Educação Continuada Alfabetização, Diversidade e Inclusão (SECADI), no ano de 1996, que tem como objetivo proporcionar aos licenciados a participação em pesquisas destinadas à área didático-pedagógica. Desde a sua implementação, o número de bolsas aumentou de 29 para 61. Além dessas iniciativas, a UFG criou três turmas especiais de graduação para atender aos excluídos da sociedade: Direito para o Campo, Pedagogia da Terra e Licenciatura Intercultural. As aulas presenciais dos cursos acontecem nas férias. Durante o curso, os alunos têm direito a transporte, alimentação e alojamento (UFG, 2008).

Em 2002, a universidade criou o projeto intitulado "Passagem do meio", elaborado por alguns docentes e discentes. A ideia foi promover a permanência de estudantes negros na instituição, concedendo bolsas e cursos de formação. A primeira seleção dos bolsistas acorreu no período de 2002 a 2003. Foram selecionados no total 45 alunos, distribuídos em alguns cursos: Ciências Sociais (11), Geografia (10), Comunicação (4), História (9), Educação (4), Filosofia (3), Biblioteconomia (1), Letras (2) e Artes (1). Esses estudantes possuíam características comuns, pois eram provenientes de famílias com condições financeiras inferiores a mil reais; a maioria dos pais com baixa escolaridade e alguns estudantes se mantinham por conta própria. Nos cursos de formação se trabalhava por módulos temáticos, tendo como tema: raça, ações afirmativas, racismo, sexualidade, educação, entre outros (CIRQUEIRA; GONÇALVES; RATTS, 2012).

\footnotetext{
${ }^{3}$ O PET é desenvolvido por grupos de alunos, com amparo de um docente tutor, organizados a partir de formações em nível de graduação das universidades brasileiras, visando à indissociabilidade entre ensino, pesquisa e extensão. O aluno e o professor tutor recebem apoio financeiro de acordo com a Política Nacional de Iniciação Científica, lembrando que somente os alunos matriculados em graduação podem participar do programa. A finalidade do PET é melhorar o ensino de graduação, a formação acadêmica, a intersdisciplinaridade e as ações coletivas (PROGRAD- PET, 2013).
} 
O grande marco do projeto a "Passagem do meio" aconteceu em 2003 com o “Seminário Universidade e Ação Afirmativa no Coração do Brasil”, que trouxe contribuições e debates sobre as relações étnico raciais e as ações afirmativas na universidade. Esse evento teve a participação do projeto "Programa Políticas da Cor na Educação Brasileira", tendo como sede as cidades de Porto Nacional, Cuiabá, Campo Grande, Belo Horizonte e Goiânia. O projeto obteve resultados positivos. Dos 28 alunos envolvidos, 19 receberam algum tipo de bolsa e, além disso, cinco estudantes foram aprovados em concurso público. Esse projeto durou seis anos, tendo fim em 2008 com a criação do programa UFG/Inclui. O programa gerou vários debates tanto na UFG quanto na sociedade goiana (CIRQUEIRA; GONÇALVES; RATTS, 2012).

Segundo a Revista UFG (2008), no ano de 2006, foi criado o Programa Universidade Saudável, visando a integrar as ações da saúde nas políticas e práticas universitárias. Também nesse ano, foi criado pelo MEC, juntamente com mais 32 instituições federais de Educação Superior, o Programa Conexões de Saberes: diálogos entre universidades e comunidades particulares, assumindo o compromisso de promover uma articulação entre as comunidades populares e as instituições universitárias, buscando garantir a permanência dos alunos provenientes das camadas populares nas universidades. Em 2007, foi implantada uma parceria com o Programa Conexões de Saberes com a Escola Aberta, em que os alunos bolsistas do Programa Conexões de Saberes em Escolas Públicas ofereciam diversas oficinas (PROEC, 2008).

No ano de 2007, efetivou-se, por meio do Programa de Bolsa Permanência (PBP), a distribuição de bolsas com o propósito de ajudar os estudantes de baixa renda a permanecerem nos cursos. Um ano depois, o programa de Reestruturação e Expansão das Universidades Federais - REUNI proporcionou a expansão da UFG no que diz respeito aos espaços físicos, bolsas estudantis e também à elevação do número de vagas.

Com o REUNI instituído pelo Decreto n 6.096, de 24 de abril de 2007, o MEC possibilitou a criação de 29 cursos de graduação, ampliou as vagas nos cursos já existentes, acarretando a expansão das vagas que antes eram de 3.963 e passaram a ser de 6.445. Houve também um aumento do número de bolsas de estudo, passando de 623 para 1.623, de auxílio alimentação que passou de 775 para 1.550, também de bolsas de mestrado que passaram de 25 para 225, e de doutorado com aumento de 6 para 66, entre outros (Revista UFG, 2008, p. 1).

A UFG, no ano de 2006 e de 2007, realizou algumas ações como a construção de centro de aulas com 29 salas, o Centro de Recursos Computacionais, o Laboratório de Análise 
e Gerenciamento de Recursos Hídricos, os novos ambulatórios e setores no Hospital das Clínicas, as Livrarias da UFG e o Centro de Cultura e Eventos (Revista UFG, 2008).

Com as várias ações promovidas pela UFG, percebe-se que a mesma vem democratizando o acesso à educação e criando políticas de acolhimento aos alunos, reconhecendo que existem diferenças individuais, socioeconômicas e culturais que interferem na maneira como é construído o conhecimento e as habilidades do sujeito no seu processo de formação. E, além disso, aposta que práticas educativas possam transformar as pessoas, sendo necessários investimentos, tempo e recursos para tal concretização (Resolução CONSUNI/ UFG, 2008).

Nessa perspectiva, a UFG desenvolve o programa UFG/Inclui, como parte de uma política de inclusão e permanência proposta pela Pró-Reitoria de Graduação (Prograd), tendo como base estudos de documentos e proposta de ações afirmativas, entre as quais estão as modalidades de vestibulares de Instituições Federais de Ensino Superior e também o “Seminário Ações Afirmativas na UFG” que objetiva propor mais debates e ações no que se refere ao acesso e à permanência dos estudantes na universidade. O programa UFG/Inclui propõe desenvolver ações afirmativas que garantam a ampliação do acesso e da permanência de alunos egressos de escolas públicas, negros egressos de escola pública e indígenas e negros quilombolas.

O Programa foi oficializado no ano de 2008, por meio da Resolução Consuni/ UFG $n^{\circ}$ 29/2008, visando a ações de acesso e permanência de alunos nos cursos de graduação oferecidos pela instituição. O compromisso declarado foi com a democratização da educação, com a socialização dos seus benefícios e com o desenvolvimento da arte, da cultura, do científico e, por último, com o tecnólogo e socioeconômico. Busca alcançar os seguintes objetivos: garantir a todos o acesso à universidade; promover a permanência e acompanhar a caminhada dos alunos, contribuindo com o seu desenvolvimento acadêmico; propor ações antes, durante e depois do processo seletivo, como veremos de forma mais detalhada ainda nesse capítulo; promover a igualdade entre as pessoas e combater ações discriminatórias. Esse programa terá duração de dez anos e será sempre avaliado, podendo sofrer alterações conforme as necessidades decorrentes do processo (Resolução CONSUNI/UFG nº 29, 2008).

Como se pode observar, a instituição não visa somente a dar o acesso, mas também a garantir a permanência dos estudantes provenientes de grupos menos favorecidos. Fazendo cumprir a esta parcela da população o direito, a oportunidade e o tratamento igual no sistema educacional, independente de classe social, cor, cultura e gênero, para que estes obtenham sucesso em seu processo educacional e profissional. 
De acordo com a Resolução Consuni/UFG no 29 (2008) a criação das ações afirmativas de cunho social foi implementada devido às diferenças existentes entre a educação oferecidas nas escolas públicas e privadas. Ao olharmos para a educação brasileira é possível evidenciar a desigualdade, a qual um expressivo grupo de pessoas não tem acesso ao ensino de qualidade, já outros grupos numericamente menores, exercem esse direito. Nota-se que, nessas últimas décadas, a qualidade de ensino das escolas públicas vem caindo gradativamente devido às más condições estruturais e à inexistência de políticas públicas efetivas. A desigualdade na educação se reflete significativamente no momento do ingresso dos alunos na universidade, sendo esses jovens, na maioria das vezes, provenientes de classes sociais menos favorecidas, que só tiveram acesso ao ensino público.

Com a pesquisa elaborada pela UNESCO em 2002 sobre as características socioeconômicas, familiares e culturais dos estudantes do ensino médio em Goiás, foi constatado que os alunos de escolas públicas têm pouco acesso à Educação Superior pública quando comparado com os alunos de escolas particulares. Constatou-se, também, que a escolaridade dos pais dos estudantes de escola pública é inferior às dos pais das escolas privadas e, além disso, o segundo grupo tem acesso a cursos extra-escolares como: curso de música, artes, prática desportiva, curso de língua estrangeira e curso de informática (Resolução CONSUNI/UFG no 29, 2008). Isso significa que e os estudantes de classe sociais privilegiadas têm oportunidade de estudar em escolas mais qualificadas do que os alunos de baixa renda. Esse fator influencia de forma expressiva a entrada nas instituições de Educação Superior pública, que por muitos anos foi elitista, inserindo somente uma parcela da população, restando às classes menos favorecidas as instituições privadas de qualidade, muitas vezes, duvidosa.

O programa UFG/Inclui, como já se observou na Resolução Consuni/UFG de 2008, prevê a inclusão social por meio de uma política de apoio aos estudantes tanto no acesso quanto na permanência plena nos cursos de graduação, por meio de ações de assistência estudantil. A Resolução Consuni também destaca que a UFG vem realizando ações de inclusão social: "No entanto, para ampliar as possibilidades de respostas às necessidades de inclusão, tais ações necessitam ser intencionalmente articuladas em um programa capaz de combiná-las com outras de maior impacto social” (CONSUNI 2008, p. 07). Dessa forma o programa UFG/Inclui tem como finalidade sistematizar essas ações, considerando as mesmas como ponto de partida para a realização de novas ações.

Das políticas/estratégias de permanência já realizada na UFG, destacamos duas: 
1) Os cursos de graduação para inclusão de grupos sociais específicos, tais como: a) Curso de Graduação em Licenciatura Intercultural Indígena que abrange Formação Superior de professores Indígenas para o ensino fundamental e médio das escolas indígenas. O curso foi criado em 2006 destinado aos povos indígenas que residem na região Araguaia-Tocantins; b) Em 2006, a UFG criou o Curso de Graduação em Direito para Beneficiários da Reforma Agrária. Participaram do curso os beneficiários da reforma agrária e pequenos agricultores, atendendo ao convênio com o Programa Nacional de Educação nas Áreas de Reforma Agrária (PRONERA) e com o Instituto Nacional de Colonização e Reforma Agrária (INCRA). Nesse mesmo currículo foi adotado o curso de direto ofertado nas cidades de Goiânia e Cidade de Goiás; c) No ano de 2007, criou o Curso de Graduação em Pedagogia-Licenciatura para Educadores do Campo, em Convênio com o Programa Nacional de Educação em áreas de Reforma Agrária, com o Instituto Nacional de Colonização e Reforma Agrária do Ministério do Desenvolvimento Agrário e com Via Campesina do Estado de Goiás. Este foi organizado em módulos tendo momentos presenciais e não presenciais.

2) Políticas de permanência dos estudantes de baixa renda: programa institucional de iniciação científica; programa de bolsa alimentação, monitoria, permanência, estágio, licenciatura, extensão e cultura; creche; moradia estudantil; serviço odontológico; programa saudavelmente $^{4}$; restaurante universitário e programa de concessão de passagens para alunos da graduação.

Segundo a Resolução Consuni/UFG nº 29 (2008), a UFG, por acreditar que as universidades podem atuar juntamente com o ensino básico de forma positiva, realiza ações antes do ingresso dos alunos na universidade com a finalidade de estimular a participação qualitativa dos estudantes que cursaram os dois últimos anos do ensino fundamental e médio em escolas públicas no processo seletivo desta instituição.

Além disso, a UFG tem como política investir na formação de professores, sendo esta uma área na qual a instituição é referência. O propósito é contribuir para a atuação do professor e também para uma melhor formação do estudante, atendendo às necessidades escolares do Estado de Goiás. Tal política abarca aspectos como a relação teoria/prática, “a articulação entre a formação inicial e a formação continuada, a interdisciplinaridade, a gestão democrática, a formação cultural, visando à formação do docente crítico, propositivo que

\footnotetext{
${ }^{4}$ O programa é desenvolvido com a finalidade de trabalhar a prevenção e recuperação da saúde mental e da dependência química dos alunos e trabalhadores da UFG e também orientá-los sobre a relação entre saúde mental e desempenho ocupacional ou acadêmico.
} 
contribua para a superação do ensino mecânico, fragmentado" (Resolução CONSUNI/UFG n ${ }^{\circ}$ 29, 2008, p. 13).

Outras ações desenvolvidas pela instituição:

1) Expansão do número de isenção de taxas do processo seletivo passando de 3.000 para 5.000, tornando a seleção mais eficiente e menos burocrática;

2) Reformulação do programa do processo seletivo articulado com a escola do ensino médio, promovendo o diálogo entre eles, ponderando acerca dos Parâmetros Curriculares Nacionais do Ensino Médio;

3) Promoção de ações voltadas para a formação de professores, apoiada em projetos realizados pelas Unidades Acadêmicas da UFG;

4) Construção de uma parceria entre a Secretaria de Educação e a Universidade, dando oportunidade para a formação inicial e continuada aos professores;

5) Criação de cursinho preparatório para o vestibular (Resolução CONSUNI/UFG $n^{\circ} 29$, 2008).

Com a ampliação no número de alunos ingressos antes por meio do sistema de cotas, a UFG, de acordo com a Resolução Consuni/UFG nº 29 (2008), pretende assegurar a presença desses em todos os cursos oferecidos pela instituição, proporcionando sua entrada em cursos de maior demanda. Para que tal fato se concretize, o programa UFG/Inclui, a partir de 2009, estabeleceu um percentual de $10 \%$ das vagas oferecidas em cada curso para os estudantes provenientes de escolas públicas que cursaram os últimos dois anos no ensino fundamental e os três anos no ensino médio, independente de cor/raça. A UFG reserva também mais $10 \%$ das vagas para os alunos de escola pública que se declararem negros e, além disso, acrescenta uma vaga por curso para os indígenas e uma vaga para os negros quilombolas, quando houver demanda.

Outro ponto elencado pela Resolução é a reserva de $20 \%$ das vagas na segunda fase do vestibular destinadas aos candidatos oriundos de escola pública e negros de escola pública que cursaram integralmente os dois últimos anos do ensino fundamental e o Ensino Médio na rede pública de ensino. Na segunda etapa do vestibular, são aproveitadas as notas do ENEM no cálculo da convocação de todos os candidatos para a segunda etapa. Se as vagas não forem preenchidas pelos participantes do programa UFG/Inclui, serão destinadas aos candidatos que escolheram concorrer por meio do sistema universal de acordo com a ordem de classificação. E, por fim, aperfeiçoamento do processo de avaliação das provas do Processo Seletivo da UFG (CONSUNI/UFG n⿳0 29, 2008). 
A Câmara de graduação da UFG aprovou em 2013 a ampliação das vagas destinadas ao Sistema de Seleção Unificado ${ }^{5}$ (Sisu). Em 2014, um total de 50\% das vagas foram preenchidas por meio do Sisu, ${ }^{6}$ que seleciona os estudantes para os cursos superiores por meio da nota do Exame Nacional do Ensino Médio, como a única etapa do processo seletivo. Houve também um aumento de $30 \%$ do número de vagas destinadas aos alunos de escola pública, seguindo as normas da Lei 12.711. Antes, esse percentual de reserva correspondia a 20\%. Essa reserva é destinada tanto para as vagas do Sisu como também para as vagas do Sistema Universal.

Segundo Gonçalves (2014), a UFG, por meio do Conselho de Ensino, Pesquisa, Extensão e Cultura, efetiva no ano de 2014, a adesão integral ao Sisu como forma de seleção. Dos 34 membros do conselho, 31 voltaram a favor da proposta e 2 se abstiveram. Lembrando que essa alteração será implementada a partir de 2015. Deste modo, todos os candidatos às vagas ofertadas pela instituição deverão fazer o Enem. A instituição, a partir do próximo vestibular de 2015, destinará 40\% das vagas ao sistema de cotas. Até 2016, este número será de $50 \%$. Os cursos que exigem teste de habilidades específicas e o sistema do UFG/Inclui (que destina vagas para quilombolas e indígenas) serão avaliados na sequência.

Destacam-se, ainda, as ações realizadas após o ingresso do estudante na universidade: expansão dos serviços de auxílio aos alunos de baixa renda; ampliação do apoio econômico; fornecimento de bolsas acadêmicas e, além disso, a busca por convênios com empresas públicas e privadas para a permanência dos alunos do programa de cotas e acompanhamento do rendimento dos estudantes e a sua inserção no mercado de trabalho.

Podemos concluir que a UFG desenvolve várias ações antes, durante e após o ingresso dos estudantes, com a finalidade de atender às suas necessidades, porém é fundamental ressaltar que os estudantes que entram pelo sistema de cotas e que visem pleitear bolsas ou alguma das ações de apoio ao acesso e à permanência devem participar do processo de seleção interna, concorrendo com os outros alunos de baixa renda da instituição, não havendo, portanto, políticas de assistência estudantil voltada especificamente para os alunos provenientes do sistema de cotas. Isso porque as ações de permanência se configuram a todos os alunos que entram na universidade.

\footnotetext{
${ }^{5}$ O Sisu é realizado pelo Ministério da Educação para selecionar os candidatos às vagas nas universidades públicas através da nota do Exame Nacional do Ensino Médio (Enem). É importante ressaltar que em 2015 a UFG aderiu integralmente ao Sisu. Desse modo, o único processo seletivo da instituição passa a ser exclusivamente por meio das notas do Enem.

${ }^{6}$ Há de considerar que alguns alunos que estudam em escolas privadas estão simultaneamente matriculados em escolas públicas. O objetivo é o de poder disputar as vagas do sistema de cotas das universidades para a escola pública.
} 
O programa UFG/Inclui passou por algumas transformações, sendo sempre avaliado, com a intenção de desenvolver um trabalho mais coerente de acordo com a realidade da instituição. Em 2010, a Faculdade de Letras, por meio da Resolução Consuni/UFG no 20/2010, solicitou à reitoria que fosse implementado o curso de Letras Libras no programa UFG/Inclui, com a finalidade de ampliar a presença dos alunos surdos no curso. Do total de vagas oferecidas em 2001 no curso de Libras, 15 foram para os candidatos surdos, sendo estes submetidos a um processo seletivo especial, com prova filmada e projetada em libras. $\mathrm{O}$ candidato, que opta em participar do processo seletivo pelo programa UFG/Inclui - Curso de Letras: Libras precisa apresentar laudo médico comprovando a deficiência auditiva.

O programa UFG/inclui também precisou se adequar às exigências da Lei 12.711/2012. Mesmo que essa nova lei tenha exigido que 50\% das vagas fossem destinadas aos estudantes de escolas públicas, no primeiro ano de implementação a UFG manteve a política de cotas já existente na universidade, reservando $20 \%$ das vagas para os estudantes egressos de escolas públicas. Nos anos seguintes gradativamente houve um aumento desse percentual a fim de atingir os $50 \%$ previstos para 2016. Nesse novo cenário, continuará, por enquanto, valendo as duas formas já existentes de ingresso na UFG: sendo 80\% das vagas para o processo seletivo, via sistema universal e $20 \%$ via Sisu, exceto para os cursos que exigem verificação de habilidades e conhecimentos específicos. Os dois sistemas já contam com a reserva de vagas para estudantes provenientes de escolas públicas.

Com a lei 12.711/2012, a entrada na UFG passou a ocorrer de três maneiras: pelo Sistema UFG/Inclui, destinado aos estudantes quilombolas, indígenas e alunos surdos; pelo Sistema Universal e Sistema de Reserva de Vagas, conforme a Lei 12.711/2012, que reserva vagas para alunos de escolas públicas, negros, pardos e indígenas, dentro de duas faixas de renda de acordo com a lei. As vagas do sistema de cotas serão distribuídas para os alunos negros, pardos e indígenas e aos demais alunos de escola pública, de acordo com o levantamento do IBGE em relação ao estado de Goiás. 
Figura 1: Sistema de preenchimento da reserva de vagas do processo seletivo 2013/1 Lei 12.711 - UFG

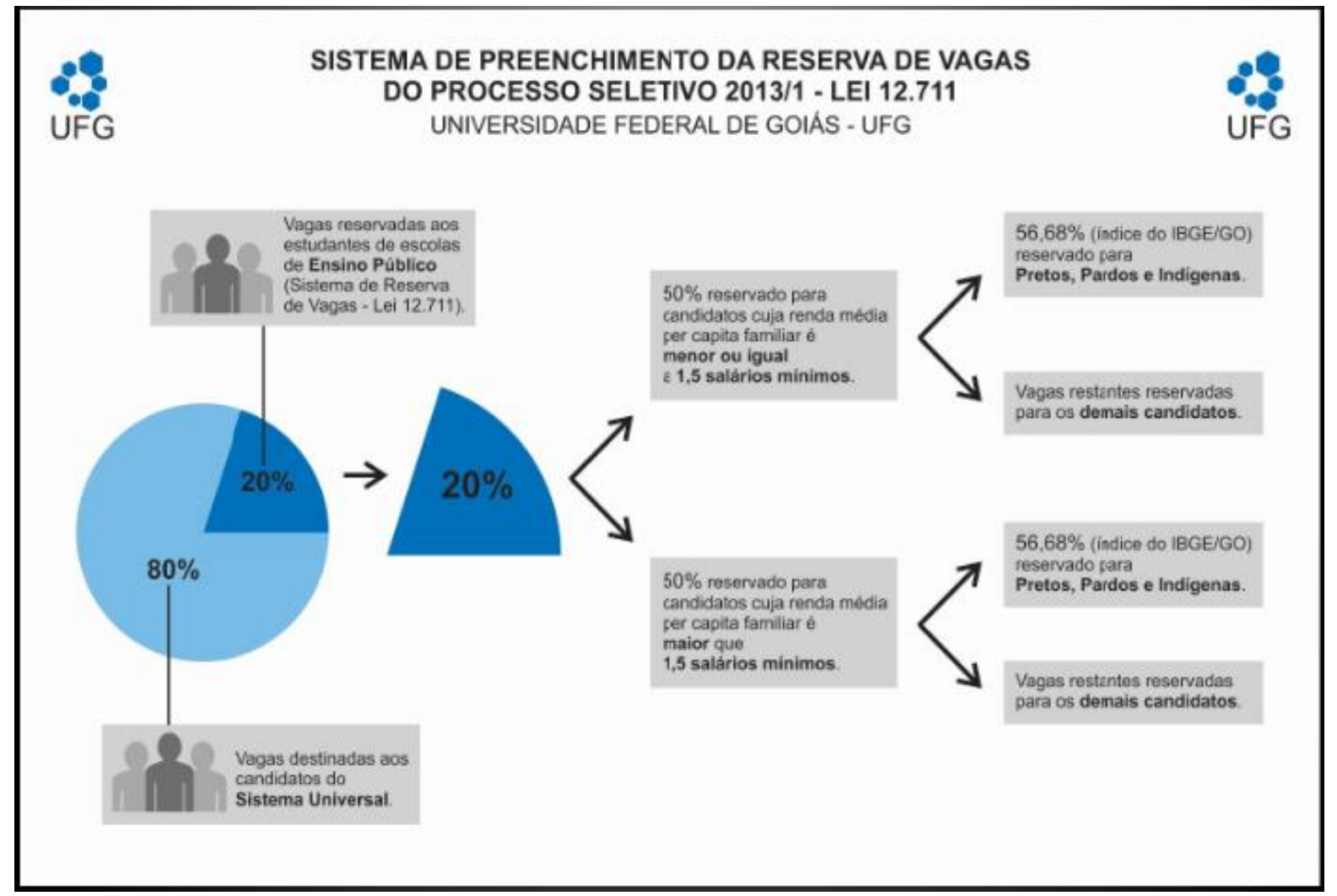

Fonte: UFG/Inclui, 2013.

Com as modificações ocorridas na UFG por meio da lei de 12.711, os alunos que antes deveriam ter cursado os últimos cinco anos em escola pública poderão ter cursado somente os três últimos anos, critério esse correspondente ao processo seletivo e ao Sisu. Outra mudança é a necessidade de comprovação de renda dos candidatos da escola pública. Haverá também a reserva de uma vaga adicional por curso para estudantes quilombolas, uma vaga para os alunos indígenas e também quinze vagas para os estudantes surdos no curso de Letras-Libras. Os candidatos negros e indígenas devem se autodeclarar, tendo o compromisso de comprovar tal fato (ASCOM, 2012).

As vagas reservadas só serão destinadas a alunos de escola pública que tenham feito todo o seu Ensino Médio em instituição pública, em cursos regulares ou em cursos de educação de jovens e adultos. E também àqueles que tiverem certificado conforme o resultado do Exame Nacional de Ensino Médio (ENEN) e os que possuam o certificado do Exame Nacional para Certificação de Competências de Jovens e Adultos - ENCCEJA ou certificado de jovens e adultos validados pelos sistemas estaduais de ensino (Edital 031/2013).

Além das ações que já promove por meio do programa UFG/Inclui, A UFG se compromete a repensar a adesão a outras propostas como a Resolução Consuni/UFG 20/2010 
e a Lei 12.711/2012 que garantem o acesso dos alunos que se encontram à margem da sociedade, principalmente no que se diz respeito à educação. 


\section{ALUNOS DAS LICENCIATURAS QUE ENTRARAM PELO SISTEMA DE COTAS NA UFG REGIONAL GOIÂNIA}

Escolhemos os cursos de licenciaturas, porque visamos discutir a importância das políticas de reconhecimento do outro no desenvolvimento da profissão docente. Inicialmente, intencionamos trabalhar com todos os cursos de licenciaturas presenciais e a distância, mas devido ao número expressivo de cursos e a dinâmica do trabalho selecionamos somente os cursos de licenciaturas presenciais. Optamos pela UFG Regional Goiânia em vista do prazo para a realização da pesquisa, já que a instituição possui outras regionais instaladas em várias cidades no Estado de Goiás.

2.1 As cotas nos cursos de licenciaturas das instituições de Educação Superior

Antes de abordamos os cursos de licenciaturas presenciais da UFG, apresentaremos dados referentes ao ingresso de alunos nos cursos de licenciaturas nas instituições de Educação Superior brasileiras com o objetivo de apreendermos como elas vêm ampliando o acesso e proporcionando aos estudantes a permanência nos cursos. Segundo Moura (2013), em 2002, 326.607 alunos foram matriculados nos cursos de licenciatura nas instituições de Educação Superior. Em 2010, os estudantes ingressos em licenciatura corresponderam a 452.527; no ano de 2011, foram 454.715, e já em 2012, o total foi de 491.087. Isso significa que houve um aumento de 50,36\% no número de ingressantes do ano de 2002 até 2012. Consequentemente o número de estudantes no ano de 2012 foi maior se comparado aos outros anos.

Como já visto, há uma quantidade significativa de pessoas que começaram os cursos de licenciatura em 2012 em relação a 2011, mas, de acordo com Moura (2013, p. s/n) infelizmente o número de concluintes teve um declínio comparando-se ao ano de 2011 . No ano de 2012, o número de estudantes que concluíram o curso foi de 223.892, e em 2011 totalizaram 238.107. "Além disso, o crescimento do número de concluintes não foi contínuo houve alguns anos de queda em relação a medições anteriores, caso de 2006 (188.963) e 2007 (184.105) comparados a 2005 (207.834), e caso de 2010 (233.306) comparado a 2009 (241.536)".

Os dados apresentados por Moura (2013) nos permitiram verificar uma maior inserção dos estudantes nos cursos de licenciatura no decorrer dos anos. Mas, ao observamos o número de alunos concluintes, notamos uma quantidade inferior em relação ao número de alunos 
ingressos. Frente a isso apresentaremos um quadro referente aos dados dos alunos que entraram e concluíram os cursos de licenciatura nas instituições federais no período de 2009 a 2012, com a finalidade de explicitar a inserção dos estudantes nessas instituições, considerando os alunos ingressos por meio do sistema universal e do sistema cotas.

Quadro 1: Número de alunos ingressantes e concluintes que entraram pelos sistema universal e sistema de cotas nos cursos de licenciatura no Brasil período de 2009 a 2012

\begin{tabular}{|c|c|c|c|}
\hline $\begin{array}{c}\text { Ingressantes - alunos } \\
\text { sem Cotas }\end{array}$ & $\begin{array}{c}\text { Ingressantes - alunos } \\
\text { com Cotas }\end{array}$ & $\begin{array}{c}\text { Concluintes - alunos } \\
\text { sem Cotas }\end{array}$ & $\begin{array}{c}\text { Concluintes - alunos } \\
\text { com Cotas }\end{array}$ \\
\hline 186.644 & 21.706 & 81.916 & 1.944 \\
\hline
\end{tabular}

Fonte: Inep, $2014^{7}$

Ao fazermos uma comparação entre os estudantes ingressantes e concluintes podemos certificar um número expressivo de desistência nos cursos de licenciatura nas universidades brasileiras, tanto os provenientes do sistema de cotas quanto os do sistema universal. Os dados do quadro 1 nos permitem também afirmar que o número de alunos que ingressam via sistema universal é maior do que os ingressantes pelo sistema de cotas.

\subsection{O programa UFG/Inclui: as licenciaturas}

Visto a questão do número de ingressantes e concluintes dos cursos de licenciatura do sistema de cotas e universal nas universidades públicas brasileiras, buscaremos dar ênfase ao nosso campo de pesquisa, a UFG. Nesse sentido, podemos dizer que a universidade desde 2009 vem democratizando o acesso à Educação Superior através do programa UFG/Inclui e da Lei 12.711, garantindo o ingresso de alunos que ao longo da história foram excluídos da universidade. Com a política de cotas, a UFG passa a ser mais diversificada e plural, não atendendo somente a uma parcela da população, mas estendendo aos pobres, negros, indígenas, quilombolas e surdos a possibilidade de se formarem e conquistarem seus espaços na sociedade.

Para a realização desta pesquisa, trabalhou-se, inicialmente com os dados de candidatos inscritos no Programa UFG/Inclui. O objetivo foi averiguar como a UFG, por meio deste programa, vem ampliando o acesso aos alunos provenientes do sistema de cotas.

\footnotetext{
${ }^{7}$ Existem outras formas de acesso que não foram consideradas no quadro, como: acréscimo de vagas, bônus e outras.
} 
Gráfico 1: Total de candidatos inscritos no programa UFG/Inclui período de 2009

a 2012

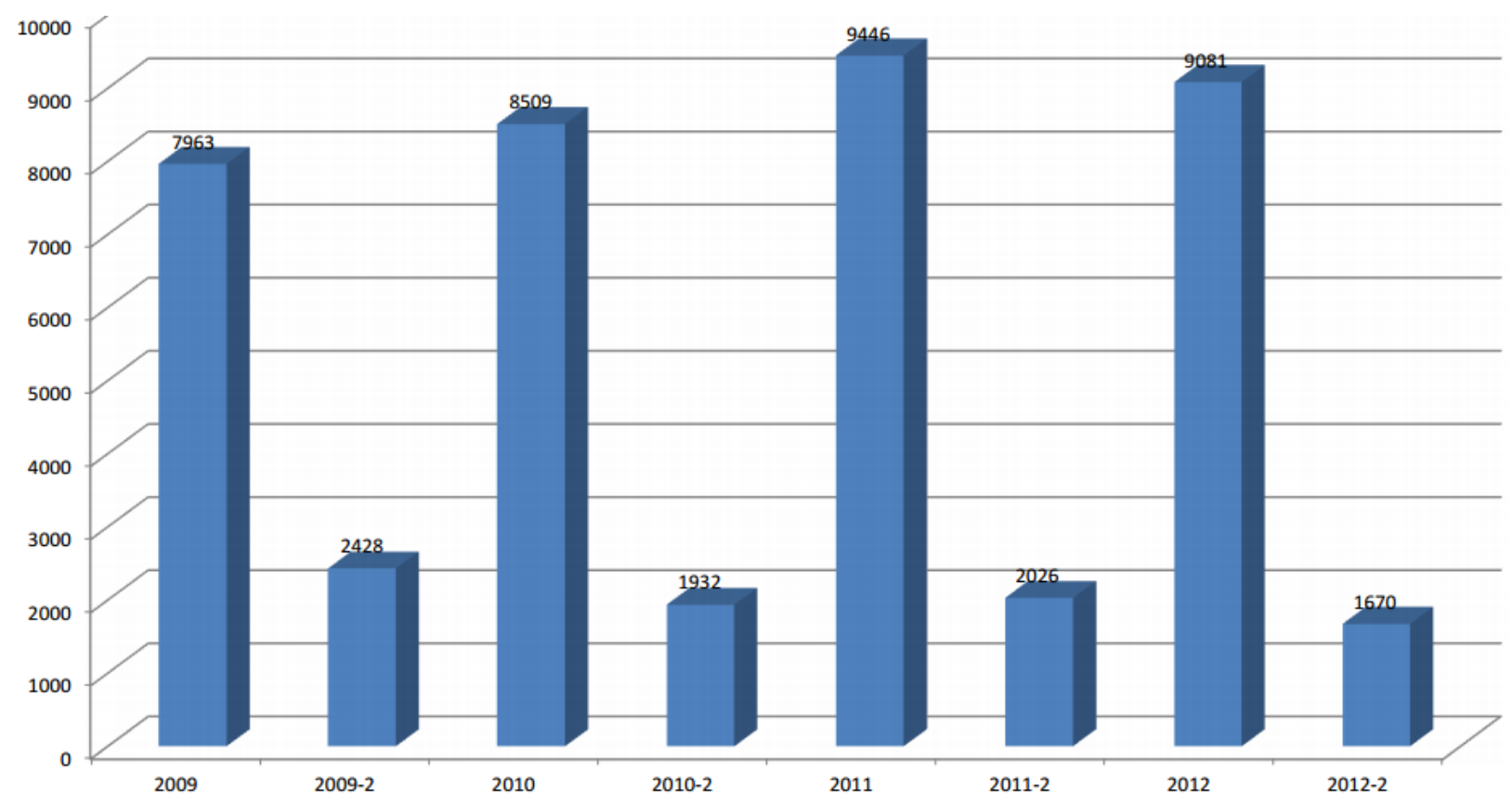

Fonte: Seminário Programa UFG/ Inclui 2013(http://www.prograd.ufg.br/)

Conforme o gráfico 1, no primeiro semestre de 2009, 7.963 alunos foram inscritos, e no segundo semestre desse mesmo ano, 2.428. No ano de 2010, no primeiro semestre, 8.509 estudantes se inscreveram, e no segundo semestre, 1.932. Em 2011, no primeiro semestre, 9.446 alunos foram inscritos, no segundo semestre totalizou 2.026. Já em 2012, foram 9.081 no primeiro semestre e no segundo, 1.670. Assim, pode-se dizer que no ano de 2011, houve um número maior de candidatos inscritos no programa UFG/Inclui do que nos anos de 2009 e 2010. E no segundo semestre do ano de 2009 e 2010, o número de inscritos foi menor do que o do primeiro semestre, pois nem todos os cursos abrem vagas no segundo semestre do ano.

Ao ser retratada a quantidade de alunos que optaram pelo programa UFG/Inclui, faz-se necessário abarcarmos o número de candidatos inscritos segundo a categoria ${ }^{8}$ do programa UFG/Inclui, no período de 2009 a 2012. Com o objetivo de certificarmos se as categorias vêm sendo preenchidas e quais destas apresentam uma maior quantidade de estudantes inscritos. Somente assim será possível analisar e promover ações de assistências coerentes com tal realidade.

\footnotetext{
${ }^{8}$ As categorias: escola pública, escola pública e negro, indígena, negro quilombola e libras são referentes a nomenclatura utilizada pela UFG.
} 


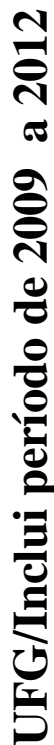

皆

ชั

m

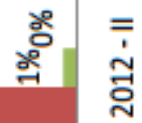

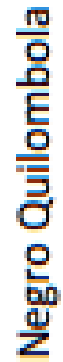

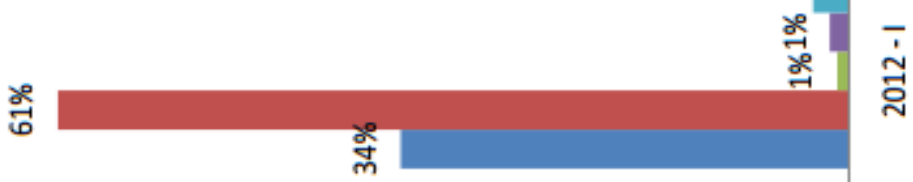

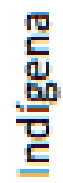

ำ

ชั

홍

ฌึ

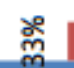

홍

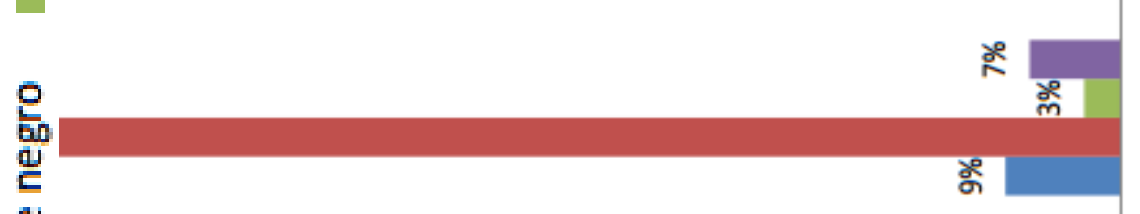

음

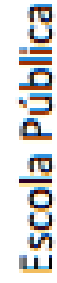

ชั

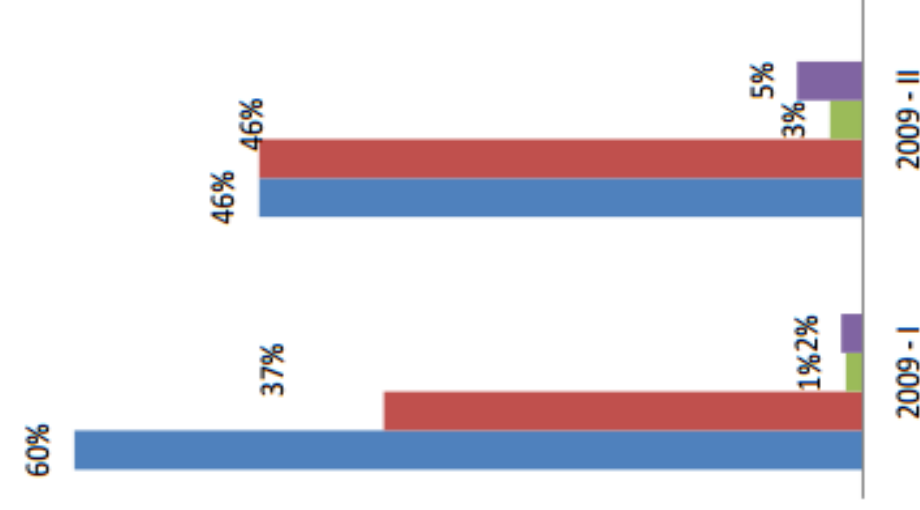

狝

今్

$\frac{8}{6}$

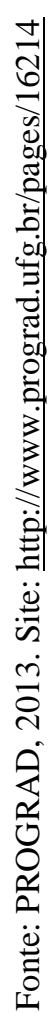


Conforme os dados fornecidos pela PROGRAD (2013) no gráfico $2^{9}$ notamos que, em todos os anos, o maior número de candidatos aprovados equivaleu à categoria escola pública, menos no segundo semestre de 2009 e 2010 e no primeiro semestre de 2012. Em seguida, escola pública e negro; depois, negro quilombola e, por último, indígenas. Não foi apresentada a porcentagem dos alunos do curso de libras.

Em relação ao ingresso dos indígenas, Cordeiro (2010) afirma que os mesmos procuram a universidade com a finalidade de obter conhecimentos fundamentais que os proporcionem liderar e defender seu grupo em todos os âmbitos. Já para os negros, a universidade se caracteriza como a possibilidade de acesso: "considerando o alto índice de pobreza detectado entre os negros (pretos e pardos). Além disso, representa ainda uma forma de elevação da auto-estima e (re) construção de sua identidade étnico-racial." (CORDEIRO, 2010, p. 99)

Percebe-se que nos anos de 2009 a 2012, o número de alunos aprovados foi oscilando. O ano de 2010, no primeiro semestre, teve a maior porcentagem de candidatos aprovados pela categoria escola pública. No segundo semestre de 2010, o maior percentual foi dos alunos de escola pública e negro. Já os aprovados, no que se refere às categorias indígenas e negros quilombolas, foram mais expressivas nos anos de 2009 e 2010, ambos no segundo semestre. Isso significa que as instituições federais de educação no Brasil estão ampliando as oportunidades para os grupos sociais de alguma forma desfavorecidos. Esse fato fica evidente com os dados apresentados pelo Instituto Nacional Anísio Teixeira (Inep) e no artigo de Moura (2013). Como vimos nos números expostos pelo programa UFG/Inclui, a UFG é um exemplo dessas instituições que vêm ampliando o acesso de estudantes menos favorecidos, não privilegiando somente a classe hierárquica como ocorreu durante muitos anos, contribuindo, assim, para a diminuição das desigualdades sociais. Porém, acreditamos que essa ação precisa ainda ser ampliada e melhor planejada, pois ainda há um índice considerável de alunos que não conclui os cursos.

Constatado que o número de alunos ingressos na UFG está se expandindo nos últimos anos por meio das políticas de inclusão, faz-se necessário apreendermos a quantidade de alunos ingressos nos cursos de licenciatura da UFG provenientes de escolas públicas e particulares e, além disso, verificar as categorias optadas pelos estudantes no período de 2011 a 2014.

\footnotetext{
${ }^{9}$ A porcentagem do gráfico 2 equivale aos números da gráfico 1.
} 
No que se refere à opção de participação dos estudantes das licenciaturas no processo seletivo e à escola proveniente no período de 2011 a 2012, o Centro de Seleção da UFG informou o seguinte:

Quadro 2: Opção de participação dos estudantes das licenciaturas no processo seletivo e a escola proveniente 2011 a 2012

\begin{tabular}{|l|c|c|}
\hline Opção de participação & Escola Pública & Escola Particular \\
\hline UFG/Inclui - Libras & 2 & \\
\hline UFG/Inclui - Negro Quilombola & 3 & \\
\hline Universal & 432 & 971 \\
\hline Escola pública & 562 & \\
\hline Escola pública e Negro & 96 & \\
\hline
\end{tabular}

Fonte: Centro de Seleção/UFG, 2014.

Como observamos a opção de participação com o percentual maior de inscritos foi universal escola particular, já o menor foi UFG/Inclui- Libras. Quando comparamos escola particular e escola pública, certificamos que o número de estudantes de escola pública inscritos no sistema de cotas para os cursos de licenciatura tem pouca diferença em relação aos da escola particular. É necessário salientar que, no ano de 2011 a 2012, não houve a inscrição de alunos indígenas.

O quadro 2 apresenta os dados referentes a opção de participação (demais candidatosrenda superior, demais candidatos-renda inferior, PPI- renda inferior, PPI- renda superior, UFG/Inclui/Libras, UFG/Inclui/negro quilombola e universal $)^{10}$ dos estudantes das licenciaturas no processo seletivo e a escola proveniente no período de 2013 a 2014.

Quadro 3: Opção de participação dos estudantes das licenciaturas no processo seletivo e a escola proveniente 2013 a 2014

\begin{tabular}{|l|c|c|}
\hline Opção de participação & Escola Pública & Escola Particular \\
\hline Demais Candidatos - Renda Superior & 228 & \\
\hline Demais Candidatos - Renda Inferior & 60 & \\
\hline PPI - Renda Inferior & 52 & \\
\hline PPI - Renda Superior & 218 & \\
\hline UFG/Inclui - Libras & 1 & \\
\hline UFG/Inclui - Negro Quilombola & 3 & \\
\hline Universal & 299 & 631 \\
\hline
\end{tabular}

Fonte: Centro de Seleção/ UFG, 2014.

\footnotetext{
${ }^{10}$ Demais candidatos refere-se aos alunos de escola pública e PPI (preto, pardos ou indígenas). Essa mudança nas opções de participação se deu com a Lei 12.711/2012.
} 
Com esses dados, é possível registrar que, no período de 2013 a 2014, a opção mais escolhida foi a universal escola pública e a universal particular. Ao olharmos para a questão da renda, percebemos que, tanto na categoria demais candidatos quanto no PPI a renda superior tem mais inscritos que a renda inferior.

Segundo Lázaro, Calmon, Lima e Oliveira (2012) "a participação dos jovens de 18 a 24 anos que integram o grupo dos $20 \%$ com menor rendimento da população teve um relevante aumento na porcentagem de matrículas no ensino superior." Com esse resultado, os autores acreditam que as políticas de inclusão dos alunos com menor renda, de certo modo, estão sendo garantidas: “(...) mas o desafio é aumentar a velocidade do crescimento dessa participação e garantir políticas de permanência que levem esses jovens à conclusão dos cursos que escolheram, dentro dos prazos acadêmicos" (LÁZARO, CALMON, LIMA E OLIVEIRA, 2012, p 5-6).

Já Queiroz e Santos (2006) nos mostram que na Universidade Federal da BahiaUFBA, por exemplo, a participação dos alunos provenientes de escolas públicas cresceu no ano de 2005, chegando a um percentual de 51\% com o sistema de cotas; antes da implementação do sistema, era de 38\%. Apesar de em 2006 essa porcentagem ter diminuído para $44,9 \%$, ainda se mantém em um nível mais alto ao que é pretendido pelo sistema de cotas.

É interessante notarmos, observando o quadro 2 que houve uma quantidade maior de inscrições dos alunos de escola particular e de escola pública do que o observado no quadro 3. Dessa forma, podemos frisar que o número de estudantes que entram em cursos de licenciatura por meio das cotas e do sistema universal vem diminuindo no decorrer dos anos. Outro fator que chama a atenção ao se observar os dois quadros, é que o número de alunos optante pela categoria UFG/Inclui- Libras e UFG/Inclui - negro quilombola é baixa se comparado às outras categorias.

Buscaremos agora analisar a questão do gênero dos estudantes, com o objetivo de identificarmos se há predominância de algum gênero nos cursos de licenciatura da UFG. 
Gráfico 3: Quantidade de alunos inscritos na UFG nos cursos de licenciatura de acordo com o gênero - 2011 a 2012.

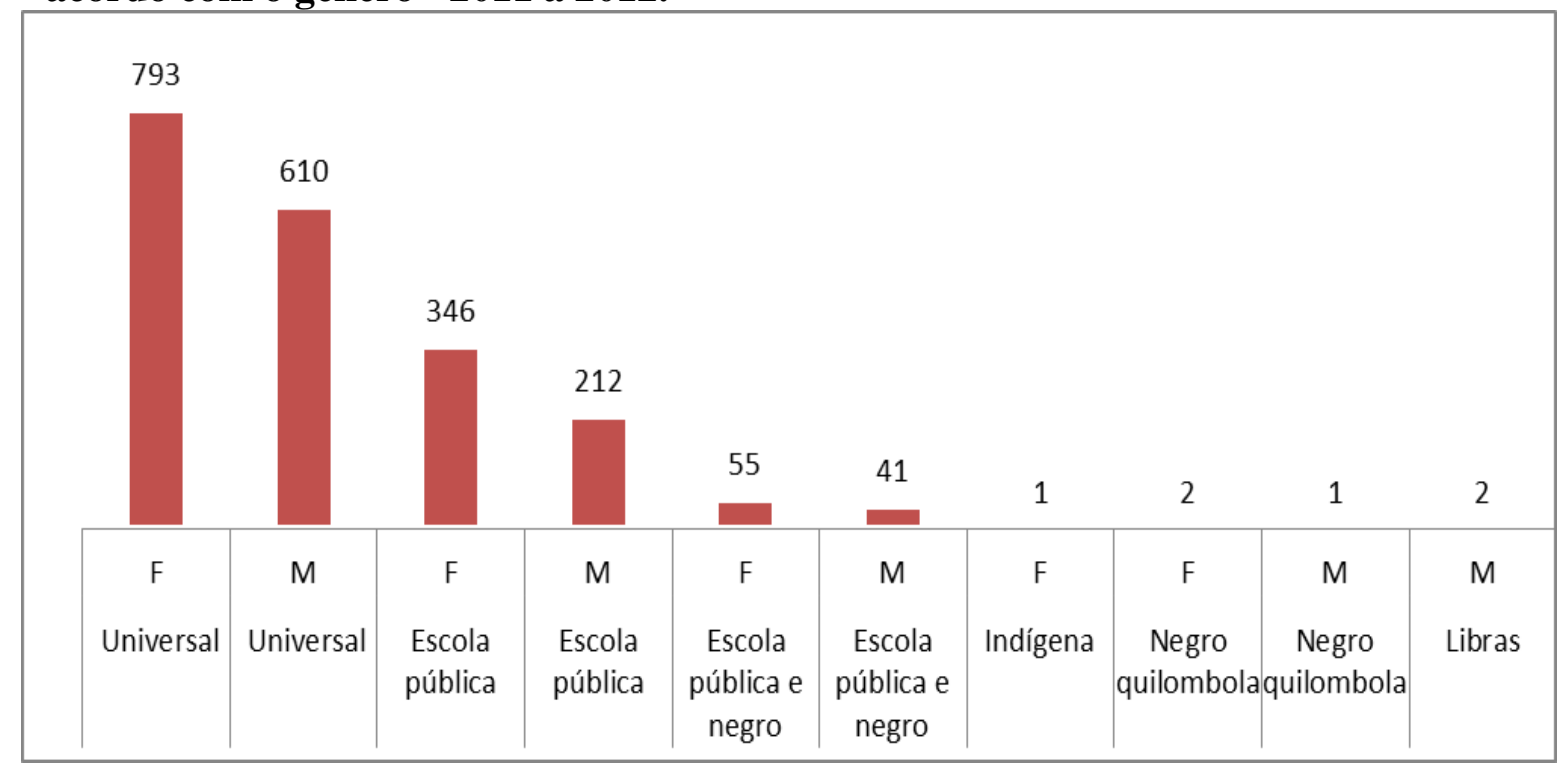

Fonte: Centro de Seleção/UFG, 2014.

Os dados nos mostram que, no ano de 2011 a 2012, o gênero feminino foi o mais representativo em todas as categorias, menos em libras, pois não teve inscrição do gênero feminino. Nesse período, não houve a inscrição do gênero masculino na categoria indígena. 

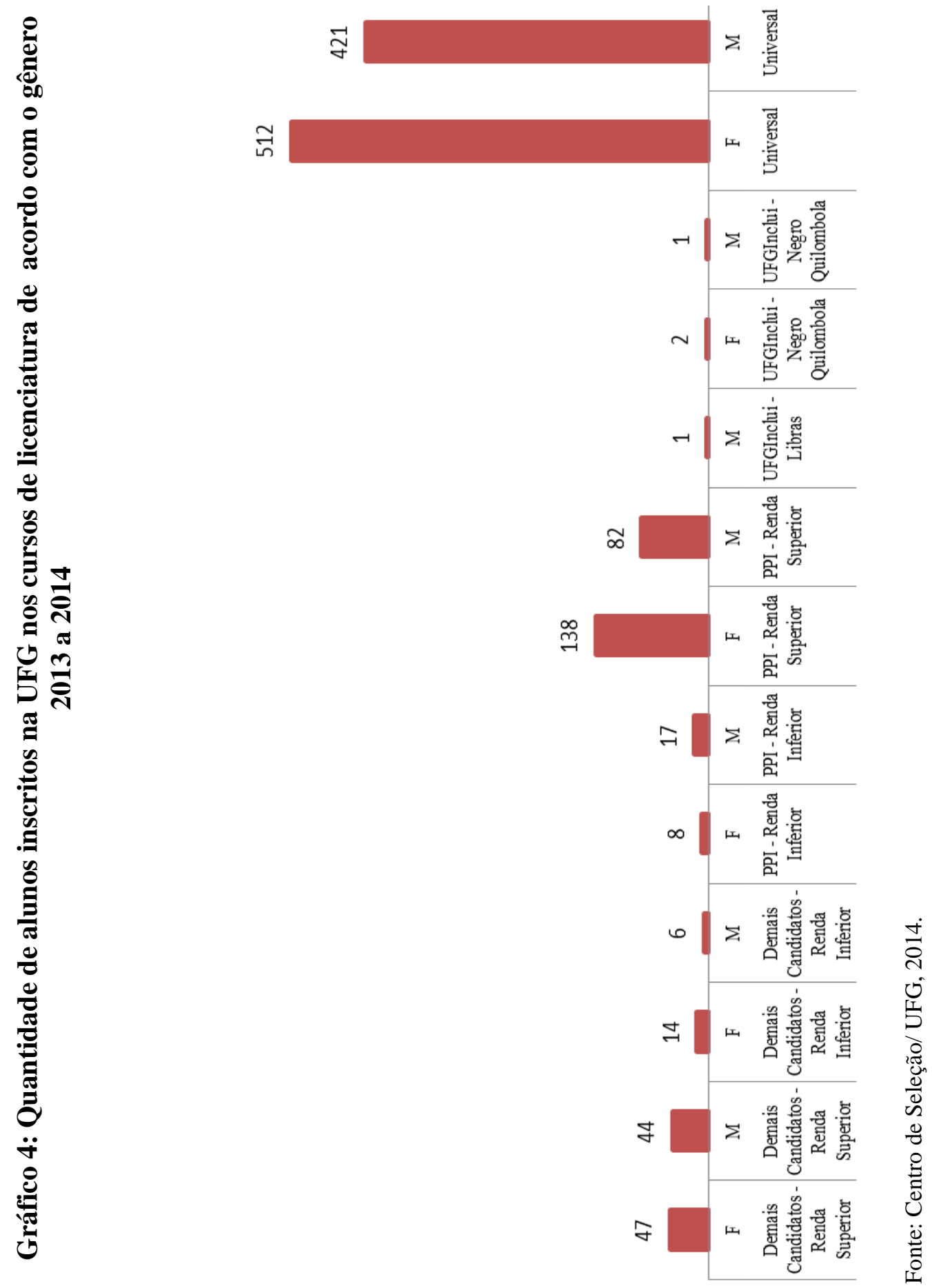
Pelo gráfico 4, também nos certificamos de que o número de candidatos inscritos, segundo o gênero feminino é maior em quase todas as categorias, menos em PPI-Renda inferior e em libras, as quais não houveram inscrições do gênero feminino.

Nos dois gráficos, no que se referem à questão gênero, ambos apresentam uma diferença entre a entrada na universidade de alunos do gênero feminino e do masculino. Esse fato é decorrente das conquistas que as mulheres vêm adquirindo no espaço social, ao assumirem outros papeis além do de dona de casa, buscando a garantia de seus direitos, dos quais foram privadas durante vários anos, devido a valores impostos pela nossa sociedade, que as impediram de estudar e de se inserirem no mercado de trabalho. A Constituição de 1988 foi um marco no sentido de garantir às mulheres igualdade de seus direitos e deveres. No entanto, sabemos que muitas conquistas ainda deverão se concretizar para as mulheres, para que haja um mundo mais justo, em que todos sejam tratados com direitos iguais.

Outro fator a ser analisado é a questão da renda mensal da família dos alunos do sistema de cotas, uma vez que esta nos possibilitará apreendermos como se caracteriza a questão financeira destes estudantes, verificando se as suas dificuldades de permanência na universidade estão ligadas a esse fator.

Tabela 1: Renda mensal da família dos alunos que optaram pelo sistema de cotas 20112014

\begin{tabular}{|l|l|l|l|l|l|l|l}
\hline Renda Mensal & $\mathbf{2 0 1 1 - 1}$ & $\mathbf{2 0 1 1 - 2}$ & $\mathbf{2 0 1 2 - 1}$ & $\mathbf{2 0 1 2 - 2}$ & $\mathbf{2 0 1 3 - 1}$ & $\mathbf{2 0 1 4 - 1}$ & $\mathbf{2 0 1 4 - 2}$ \\
\cline { 2 - 7 } Até 1 Salário mínimo & $0.27 \%$ & $0.00 \%$ & $0.43 \%$ & $0.00 \%$ & $0.41 \%$ & $50.16 \%$ & $42.86 \%$ \\
\hline Entre 1 e 2 & $9.26 \%$ & $0.00 \%$ & $9.91 \%$ & $8.33 \%$ & $12.20 \%$ & $29.26 \%$ & $14.29 \%$ \\
\hline Entre 2 e 4 & $39.78 \%$ & $44.44 \%$ & $43.10 \%$ & $33.33 \%$ & $35.77 \%$ & $16.08 \%$ & $35.71 \%$ \\
\hline Entre 4 e 8 & $30.52 \%$ & $22.22 \%$ & $31.03 \%$ & $16.67 \%$ & $35.37 \%$ & $1.93 \%$ & $0.00 \%$ \\
\hline Entre 8 e 16 & $15.53 \%$ & $11.11 \%$ & $8.62 \%$ & $25.00 \%$ & $11.38 \%$ & $0.32 \%$ & $0.00 \%$ \\
\hline Entre 16 e 32 & $3.00 \%$ & $22.22 \%$ & $6.03 \%$ & $16.67 \%$ & $4.07 \%$ & & \\
\hline Entre 32 e 64 & $1.63 \%$ & $0.00 \%$ & $0.86 \%$ & $0.00 \%$ & $0.81 \%$ & & \\
\hline Acima de 64 & $0.00 \%$ & $0.00 \%$ & $0.00 \%$ & $0.00 \%$ & $0.00 \%$ & & \\
\hline
\end{tabular}

Fonte: Centro de Seleção/ UFG, 2014.

Nos anos de 2011, 2012 e 2013, como podemos perceber na tabela 1, a renda familiar dos estudantes se caracteriza com o maior percentual entre dois a quatro salários mínimos; em segundo lugar, de quatro a oito salários mínimos. Mas, no ano de 2014, a porcentagem maior corresponde até um salário mínimo por mês, com 50,16\% no primeiro semestre e $42,86 \%$ no segundo semestre. Outro dado importante a ser destacado é que, no período de 2011 a 2014 o número de alunos que possuem renda familiar de até um salário mínimo teve um aumento principalmente em 2014, chegando no primeiro semestre a 50,16\% e no segundo semestre 
com 42,86\%. Nota-se, também que são poucos os estudantes que possuem renda familiar entre dezesseis a sessenta e quatro salários mínimos.

Já a renda mensal dos alunos do sistema universal da UFG dos cursos de licenciatura é mais expressiva que a dos alunos do sistema de cotas, chegando ao patamar de quatro salários mínimos. A tabela 2 nos permite constatar que em 2012 a renda mensal teve um maior destaque entre quatro a trinta e dois salários mínimos. E, além disso, podemos observar que a renda mensal dos alunos do sistema universal perpassa em todas as opções até entre 32 e 64 salários mínimos.

Tabela 2: Renda mensal da família dos alunos que optaram pelo sistema universal 20112014

\begin{tabular}{|l|l|l|l|l|l|l|l}
\hline Renda Mensal & $\mathbf{2 0 1 1 - 1}$ & $\mathbf{2 0 1 1 - 2}$ & $\mathbf{2 0 1 2 - 1}$ & $\mathbf{2 0 1 2 - 2}$ & $\mathbf{2 0 1 3 - 1}$ & $\mathbf{2 0 1 4 - 1}$ & $\mathbf{2 0 1 4 - 2}$ \\
\hline Até 1 Salário mínimo & $1.86 \%$ & $36.00 \%$ & $0.88 \%$ & $2.86 \%$ & $54.67 \%$ & $34.77 \%$ & $28.57 \%$ \\
\hline Entre 1 e 2 & $5.00 \%$ & $26.00 \%$ & $7.23 \%$ & $0.00 \%$ & $15.11 \%$ & $35.48 \%$ & $66.67 \%$ \\
\hline Entre 2 e 4 & $31.71 \%$ & $14.00 \%$ & $30.83 \%$ & $11.43 \%$ & $21.50 \%$ & $22.58 \%$ & $4.76 \%$ \\
\hline Entre 4 e 8 & $29.43 \%$ & $2.00 \%$ & $33.78 \%$ & $31.43 \%$ & $5.76 \%$ & $5.38 \%$ & $0.00 \%$ \\
\hline Entre 8 e 16 & $20.14 \%$ & $2.00 \%$ & $17.70 \%$ & $34.29 \%$ & $1.56 \%$ & $0.72 \%$ & $0.00 \%$ \\
\hline Entre 16 e 32 & $8.86 \%$ & $2.00 \%$ & $7.67 \%$ & $17.14 \%$ & $0.93 \%$ & & \\
\hline Entre 32 e 64 & $2.43 \%$ & $4.00 \%$ & $1.47 \%$ & $0.00 \%$ & $0.47 \%$ & & \\
\hline Acima de 64 & $0.57 \%$ & $14.00 \%$ & $0.44 \%$ & $2.86 \%$ & $0.00 \%$ & & \\
\hline
\end{tabular}

Fonte: Centro de Seleção/ UFG, 2014.

Ao analisarmos a tabela 1 e 2 , verificamos que a renda mensal tanto dos alunos do sistema de cotas quanto do sistema universal tem maior predominância entre um a oito salários mínimos. Dessa forma, entendemos que a renda mensal familiar dos estudantes de ambos os sistemas não tem muita variação. Nesse sentido, devemos lembrar que a maioria dos alunos dos cursos de licenciaturas apresenta uma renda mais baixa comparada aos estudantes que cursam cursos de maior prestigio. Segundo Pereira (2011, p. 43):

(...) as condições socioeconômico-culturais mais favoráveis (melhor renda, maior escolaridade e ocupações de maior prestígio) constituíram importante fator de aprovação nos cursos mais disputados da universidade. A origem sociocultural da maioria dos aprovados nos cursos com modalidade licenciatura era bem menos privilegiada que a dos alunos que optaram pelos cursos mais concorridos.

Mas, há outro fator que nos chama a atenção, são os estudantes do sistema universal que apresentam renda mensal entre 32 e 64 salários mínimos. Quando confrontamos os dados dos alunos do sistema de cotas com os dos alunos do sistema universal, certificamos que são poucos os estudantes provenientes do sistema de cotas que possuem renda mensal de 32 
salários mínimos, sendo que em nenhum dos anos chega-se a $2 \%$ a quantidade de alunos que se enquadra nessa renda. Já no que se refere à renda mensal de 64 salários mínimos, notamos que nenhum aluno do sistema de cotas possui essa renda. Isso significa que a maioria dos estudantes que procura o sistema de cotas possui uma renda familiar mensal menor comparada aos estudantes que procuram o sistema universal.

Isso representa a desigualdade em nossa sociedade, pois bem sabemos que em nosso país a distribuição econômica está muito longe de ser igual para todos. Segundo Cordeiro: "O Brasil é um dos países com a maior desigualdade na distribuição de renda do mundo. A magnitude e o crescimento dessa desigualdade geram pobreza e exclusão social, econômica e educacional cada vez maior" (CORDEIRO, 2010, p. 109). Acredita-se que as cotas sejam uma forma de garantir às famílias carentes a oportunidade de se formarem e de terem uma profissão, buscando condições melhores de vida.

Considerando a condição econômica da família dos estudantes do sistema de cotas é primordial frisarmos que muitos desses pretendem se manter na universidade trabalhando com recursos próprios, sendo essa uma forma de custear o seu estudo e até mesmo auxiliar a família. Mesmo que a universidade seja pública, há outros gastos como ônibus, cópias de texto, compra de livros, alimentação, entre outros, que os estudantes precisam custear por conta própria.

Tabela 3: Como os estudantes do sistema de cotas pretendem se manter na universidade 2011 a 2014

\begin{tabular}{|ll|l|l|l|l|l|l}
\hline \multicolumn{2}{l|}{ Como se pretende manter na universidade $\mathbf{2 0 1 1 - 1}$} & $\mathbf{2 0 1 1 - 2}$ & $\mathbf{2 0 1 2 - 1}$ & $\mathbf{2 0 1 2 - 2}$ & $\mathbf{2 0 1 3 - 1}$ & $\mathbf{2 0 1 4 - 1}$ & $\mathbf{2 0 1 4 - 2}$ \\
\hline Trabalhando com recursos próprios & $52.86 \%$ & $55.56 \%$ & $25.43 \%$ & $58.33 \%$ & $50.81 \%$ & $31.19 \%$ & $28.57 \%$ \\
\hline Com recursos dos pais & $22.62 \%$ & $0.00 \%$ & $21.12 \%$ & $8.33 \%$ & $24.39 \%$ & $1.61 \%$ & $7.14 \%$ \\
\hline Com bolsa de estudos & $20.71 \%$ & $33.33 \%$ & $3.02 \%$ & $8.33 \%$ & $21.14 \%$ & $39.55 \%$ & $14.29 \%$ \\
\hline Com ajuda de outros & $3.81 \%$ & $11.11 \%$ & $50.43 \%$ & $25.00 \%$ & $3.66 \%$ & $27.65 \%$ & $50.00 \%$ \\
\hline
\end{tabular}

Fonte: Centro de Seleção/ UFG, 2014.

Identificou-se, conforme a tabela 3, que em quase todos os anos a forma escolhida pelos alunos de se manterem na universidade foi trabalhando com recursos próprios. Somente em 2012-1 e 2014-1e 2 que esse quadro se inverte, pois uma quantidade maior de estudantes pretende se manter por meio da ajuda de outros e de bolsas de estudos. Como já vimos anteriormente, a UFG fornece bolsas para os alunos, mas as mesmas não atendem a todos.

A conciliação entre trabalho e estudo é um dos fatores apresentados que impede os estudantes de se engajarem em pesquisas, desenvolverem atividades acadêmicas e terem um 
bom desempenho nas disciplinas, prejudicando assim a sua aprendizagem, pois o tempo é limitado para se dedicarem ao curso. Um estudo realizado por Barros (2009) na Universidade Estadual do Rio de Janeiro (UERJ) certificou que uma das dificuldades dos estudantes provenientes das cotas de permanecer na universidade está vinculada à questão da dupla jornada de trabalho e de estudo, o que os obriga a optarem pelo trabalho em vez dos estudos. Com isso, uma parcela significativa de estudantes desiste dos cursos para trabalhar, sendo esta uma forma de contribuir com o sustento da família.

Já se discutiu no início deste capítulo as ações de assistência estudantis que a UFG promove aos alunos do sistema de cotas e universal, com a finalidade de garantir o acesso e a permanência, visando a contribuir com o processo acadêmico dos mesmos. Desse modo, veremos na tabela 4 os serviços complementares que os estudantes preferem que a universidade realize para atender às suas necessidades no período de 2011 a 2014. Os principais serviços são: apoio para alojamento, assistência médica e odontológica, atividade de esporte e lazer, bolsa alimentação, bolsa trabalho, programas culturais e artísticos.

Tabela 4: O serviço complementar que os estudantes do sistema de cotas preferem que a UFG realize 2011 a $2014^{11}$

\begin{tabular}{l|c|l|l|l|l|l|l}
\hline Tipo de serviço & $\mathbf{2 0 1 1 - 1}$ & $\mathbf{2 0 1 1 - 2}$ & $\mathbf{2 0 1 2 - 1}$ & $\mathbf{2 0 1 2 - 2}$ & $\mathbf{2 0 1 3 - 1}$ & $\mathbf{2 0 1 4 - 1}$ & $\mathbf{2 0 1 4 - 2}$ \\
\hline Apoio para alojamento & $6.81 \%$ & $11.11 \%$ & $5.17 \%$ & $8.33 \%$ & $6.10 \%$ & $9.32 \%$ & $7.14 \%$ \\
\hline $\begin{array}{l}\text { Assistência médica e } \\
\text { odontológica }\end{array}$ & $7.63 \%$ & $0.00 \%$ & $8.19 \%$ & $0.00 \%$ & $8.54 \%$ & $8.04 \%$ & $7.14 \%$ \\
\hline $\begin{array}{l}\text { Atividades de esportes e } \\
\text { lazer }\end{array}$ & $6.54 \%$ & $0.00 \%$ & $5.17 \%$ & $25.00 \%$ & $6.10 \%$ & $4.82 \%$ & $7.14 \%$ \\
\hline Bolsa e alimentação & $12.26 \%$ & $11.11 \%$ & $11.21 \%$ & $16.67 \%$ & $15.45 \%$ & $18.65 \%$ & $21.43 \%$ \\
\hline Bolsa de trabalho & $58.86 \%$ & $55.56 \%$ & $57.76 \%$ & $50.00 \%$ & $56.10 \%$ & $50.16 \%$ & $42.86 \%$ \\
\hline $\begin{array}{l}\text { Programas culturais e } \\
\text { artísticos }\end{array}$ & $7.90 \%$ & $22.22 \%$ & $12.50 \%$ & $0.00 \%$ & $7.72 \%$ & $9.00 \%$ & $14.29 \%$ \\
\hline
\end{tabular}

Fonte: Centro de Seleção/ UFG, 2014.

Com os dados apresentados na tabela 4, é possível certificarmos que os alunos estão mais interessados na bolsa de trabalho e na bolsa alimentação. As opções menos escolhidas foram assistência médica odontológica, apoio para alojamento, atividade de esportes e lazer e programas culturais e artísticos. Desde 2011 a 2014, o tipo de serviço mais escolhido foi bolsa trabalho, nenhuma das outras opções teve uma porcentagem maior. No ano de 2011-1, a porcentagem foi de 58.86\%, tendo uma redução em 2012-2, 2014-1 e 2014-2, mas essa redução foi pouco significativa.

\footnotetext{
${ }^{11}$ O centro de seleção da UFG não informou os dados do ano de 2013-4.
} 
O sistema de cotas é uma forma de inserção de alunos que, por muito tempo, não tiveram a oportunidade de frequentar a Educação Superior. Essa política na UFG exige que os estudantes que optarem por tal sistema tenham estudado em escola pública, sendo essa também uma exigência da lei 12.711. A tabela 5 nos ajudará a compreender melhor se os oriundos do sistema de cotas entram na universidade somente com o ensino oferecido nas instituições públicas de Educação Básica ou se frequentaram cursinho ou outras formas de preparação para o vestibular. A revisão realizada das matérias dos anos anteriores é uma forma de preparação dos alunos.

Tabela 5: Forma de preparação dos alunos que optaram pelo sistema de cotas para entrarem na universidade 2011 a $2014^{12}$

\begin{tabular}{l|l|l|l|l|l|l|l|}
\hline & $2011-1$ & $2011-2$ & $2012-1$ & $2012-2$ & $2013-1$ & $2014-1$ & $2014-2$ \\
\hline Não & $59.40 \%$ & $55.56 \%$ & $53.88 \%$ & $41.67 \%$ & $69.92 \%$ & $65.92 \%$ & $35.71 \%$ \\
\hline $\begin{array}{l}\text { Não, mas o 3 }{ }^{\circ} \text { ano incluiu revisão dos } \\
\text { anos anteriores }\end{array}$ & $3.27 \%$ & $0.00 \%$ & $1.29 \%$ & $8.33 \%$ & $2.85 \%$ & 4.82 & $7.14 \%$ \\
\hline Sim, menos de 1 semestre & $7.36 \%$ & $0.00 \%$ & $12.93 \%$ & $0.00 \%$ & $6.50 \%$ & $9 \%$ & $28.57 \%$ \\
\hline Sim, 1 semestre & $20.16 \%$ & $22.22 \%$ & $19.40 \%$ & $25.00 \%$ & $9.35 \%$ & $12.54 \%$ & $28.57 \%$ \\
\hline Sim, 1 ano & $5.99 \%$ & $22.22 \%$ & $10.78 \%$ & $8.33 \%$ & $5.69 \%$ & $5.14 \%$ & \\
\hline Sim, mais de um ano & $3.81 \%$ & $0.00 \%$ & $1.72 \%$ & $16.67 \%$ & $2.85 \%$ & $2.57 \%$ & \\
\hline
\end{tabular}

Fonte: Centro de Seleção/ UFG, 2014.

Como podemos observar uma porcentagem expressiva dos alunos não frequentou nenhuma forma de preparação para o vestibular. Esse fato pode estar relacionado com a questão financeira dos candidatos, que não possuem condições de frequentar cursinhos preparatórios, pois, como sabemos, a maioria dos cursinhos são particulares e caros. E, além disso, os cursinhos públicos não conseguem atender a todos os alunos.

Os dados também nos mostram que uma parcela dos estudantes fez um semestre de preparação, sendo que 2012-2 e 2014-2 foram os anos com mais destaque. No ano de 2011-2, um total de 22,22\% fez um ano de preparação e 16,67\% em 2012-2 se prepararam mais de um ano. Nota-se que os alunos que prestaram o vestibular no segundo semestre participaram mais de cursos pré-vestibulares em relação aos do primeiro semestre. Essa diferença pode ser explicada pela reprovação no primeiro semestre.

Optamos em apresentar os dados do Inep no que se refere à evasão com o objetivo de mostrar um panorama mais amplo dessa realidade na Educação Superior brasileira. Segundo o Inep, existe um índice considerável de desistência dos alunos nos cursos das universidades brasileiras. De acordo com o Censo de Educação Superior de 2010, nesse ano, nos cursos de

${ }^{12}$ O centro de seleção da UFG não informou os dados do ano de 2013-4. 
licenciaturas, foram matriculados 1.354.989 alunos; desta quantidade, 393.776 participaram do processo seletivo e 58.751 ingressaram por outras formas: mudança de curso dentro do Instituto Superior de Educação (IES), transferência vindo de outras IES, excluído ex-offício, transferência ex-offício, acordos internacionais, admissão de diplomados em curso superior, reabertura de matrícula. No total de matriculados, apenas 233.306 alunos concluíram o curso.

Já no ano de 2011, foi realizado, na modalidade presencial, um total de 5.746.762 matrículas, sendo que, deste total, somente 1.686.854 ingressaram por meio do processo seletivo e 228.244, por meio de outras formas, totalizando 1.915.098. Desse total, somente 865.161 concluíram o curso. Mesmo com um aumento de concluintes no ano de 2011, nota-se que, nos cursos de licenciatura, menos da metade dos estudantes permaneceram até o final do curso.

Com o propósito de identificar a evasão dos alunos que ingressaram pelo sistema de cotas da UFG, apresentam-se no gráfico 5 os dados que mostram a quantidade de alunos evadidos de acordo com cada curso de licenciatura, nos anos de 2009 a 2013.

\section{Gráfico 5: Número de alunos que entraram pelo sistema de cotas evadidos dos cursos de licenciatura UFG 2009 a 2013}

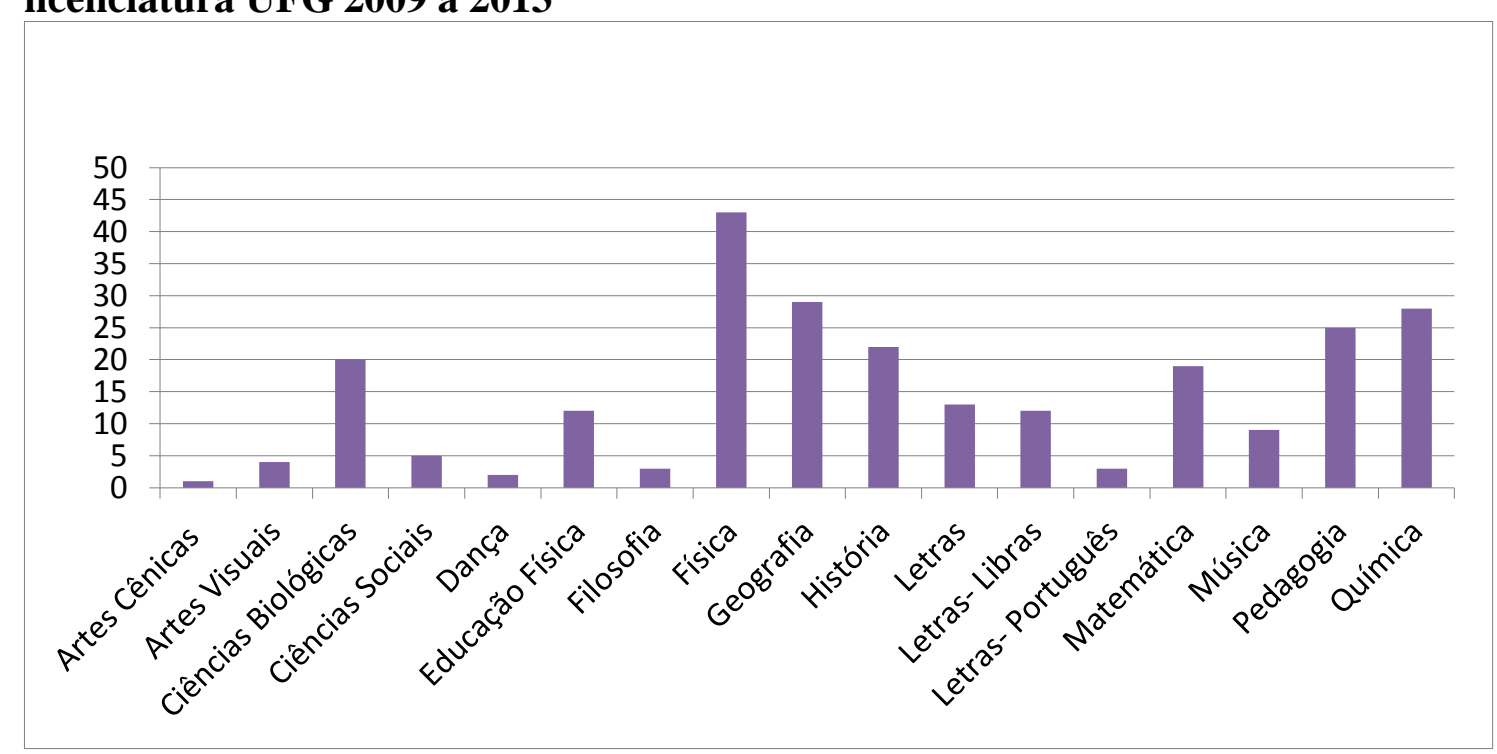

Fonte: PROGRAD UFG, 2014.

Podemos observar que todos os 17 cursos de licenciatura existentes na UFG apresentam evasão de estudantes ingressos por meio do sistema de cotas. Alguns cursos têm um índice de evasão maior do que outros, por exemplo, Física, Geografia, Química, Pedagogia, História e Ciências Biológicas. 
É importante ressaltar que a permanência dos alunos e a conclusão do curso exigem das instituições uma postura acolhedora, que evite a discriminação. Nesse sentido, é necessário que a UFG repense suas ações, buscando atender às dificuldades e às particularidades dos alunos, não garantindo somente o acesso, mas também o seu reconhecimento ${ }^{13}$ na sociedade acadêmica.

[é] sabido que a permanência desses alunos depende da combinação dos aspectos sociais, econômicos e pedagógicos. Portanto, não basta termos bolsas ou outras formas financeiras de ajuda, se no ambiente de aprendizagem as situações oferecidas forem de exclusão. Exclusão que pode estar cotidianamente presente no discurso, nos gestos e expressões do professor, dos colegas e demais envolvidos no ambiente acadêmico. Pode estar incluída de forma simbólica na avaliação da aprendizagem e até no discurso democrático feito por muitos com o objetivo de maquiar as representações negativas ou discriminatórias [...] (CORDEIRO, 2010, p. 113).

Conforme nos mostra Cordeiro (2010), as ações de permanência precisam abarcar três fatores: sociais, econômicos e pedagógicos, propiciando um ambiente de aprendizagem voltado para a inclusão, em que a diferença não seja um fator de discriminação e exclusão, de maneira que todos sejam tratados com dignidade e respeito.

Esta análise exige verificarmos o motivo da inativação dos alunos que optaram pelo sistema de cotas nos cursos de licenciatura.

\footnotetext{
${ }^{13}$ Segundo Honneth (2003) o reconhecimento é a aceitação das originalidades e capacidades de si mesmo e do outro nas relações intersubjetivas. É por meio dessas relações que o indivíduo forma a sua identidade e se autorrealiza. A busca por reconhecimento se dá em três esferas: no âmbito do amor, nas relações jurídicas e na esfera da solidariedade social.
} 


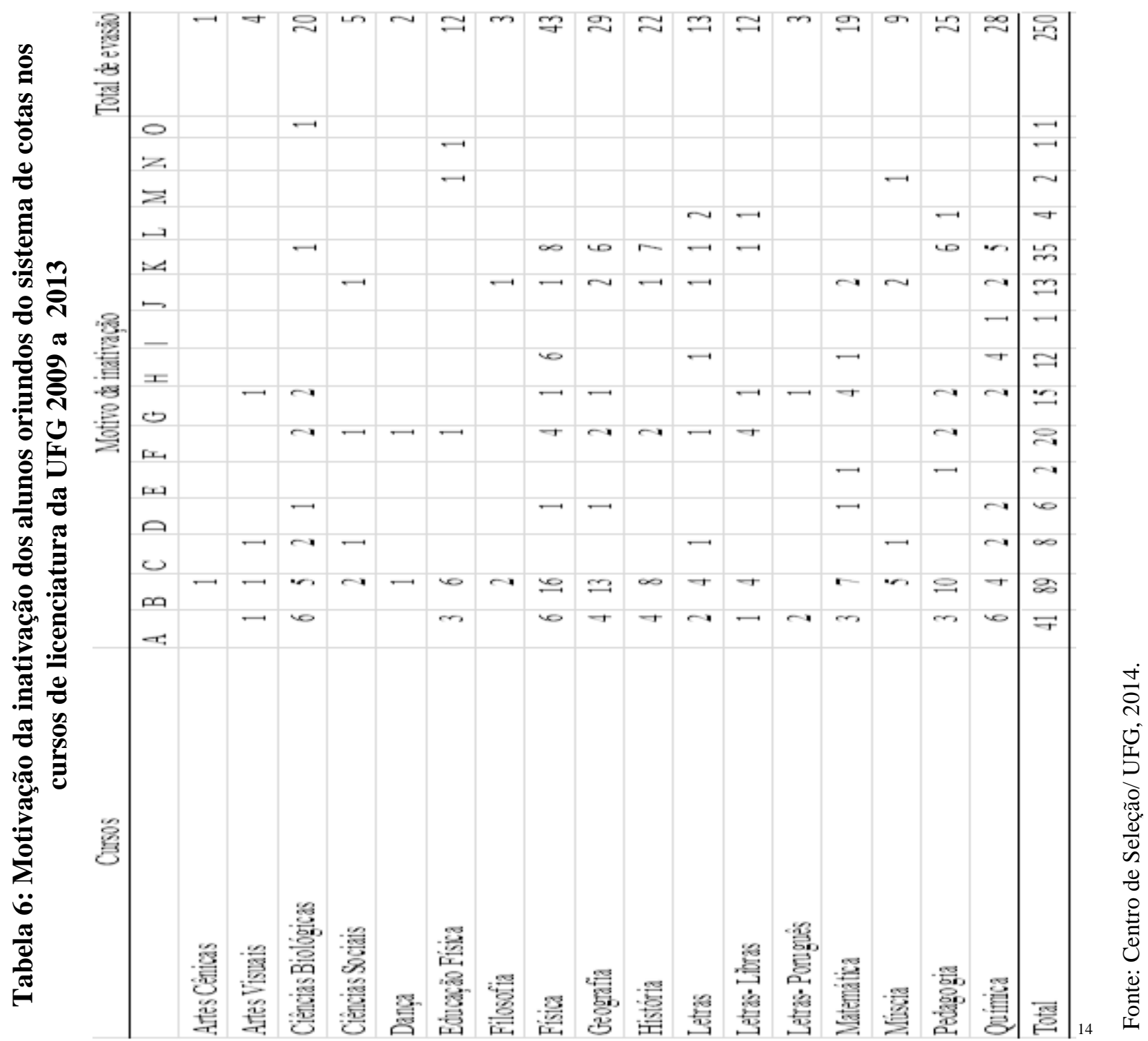

\footnotetext{
${ }^{14}$ Legenda

Desistência do curso $=\mathrm{A}$

Não efetivou matrícula $=\mathrm{B}$

Opção por outro curso $=\mathrm{C}$

Reprovação por falta 3 Vezes na mesma disciplina $=\mathrm{D}$

Reprovação por falta 3 vezes na mesma disciplina. Falta em todas $=\mathrm{E}$

Reprovação por falta em todas as disciplinas. Por 2 semestre consecutivos $=\mathrm{F}$

Reprovação por falta em todas as disciplina semestre de Ingresso $=\mathrm{G}$

$\mathrm{RM} / \mathrm{RF} 3$ vezes na mesma disciplina $=\mathrm{H}$

$\mathrm{RM} / \mathrm{RF} 3$ vezes na mesma disciplina e RM/RF em todas as disciplinas 2 semestre $=\mathrm{I}$

$\mathrm{RM} / \mathrm{RF}$ em todas as disciplinas por 2 semestres consecutivos $=\mathrm{J}$

$\mathrm{RM} / \mathrm{RF}$ em todas as disciplinas no semestre de ingresso $=\mathrm{K}$

Transferência para outro IES = L

Desvinculado por decisão judicial $=\mathrm{M}$

Desvinculado por decisão administrativa $=\mathrm{N}$

Baixa por débito de documento $=\mathrm{O}$
} 
Na tabela 6 destacam-se os motivos da inativação dos estudantes no período de 2009 a 2013, lembrando que a partir de 2009 o processo seletivo da UFG já trabalhava com o programa UFG/Inclui aprovado pela Resolução CONSUNI/UFG no 29/2008. O motivo da desistência é classificado da seguinte maneira: desistência do curso (41 alunos); não efetivou matrícula (49 alunos); opção por outro curso (8 alunos); reprovação por falta três vezes na mesma disciplina (6 alunos); reprovação por falta três vezes na mesma disciplina, falta em todas (2 alunos); reprovação por falta em todas as disciplinas, por dois semestre consecutivos (20 alunos), reprovação por falta em todas as disciplinas no semestre de ingresso (15 alunos); MR/ RF, três vezes na mesma disciplina (12 alunos); RM/RF 3 vezes na mesma disciplina e $\mathrm{RM} / \mathrm{RF}$ em todas as disciplinas 2 semestre (1 aluno); RM/RF em todas as disciplinas por 2 semestres consecutivos (13 alunos); RM/RF em todas as disciplinas no semestre de ingresso (35 alunos), transferência para outro IES (4 alunos); desvinculado por decisão judicial (2 alunos), desvinculado por decisão administrativa (1 aluno); baixa por débito de documento (1 aluno).

Nesta análise, classificamos o motivo da desistência, considerando os 17 cursos de licenciatura da UFG. O motivo da inativação com um percentual maior é devido a não efetivação da matrícula; desistência do curso; RM/RF em todas as disciplinas no semestre de ingresso; reprovação por falta em todas as disciplinas, por dois semestres consecutivos; entre outros. É possível constatar que a reprovação por média está vinculada também à reprovação por falta.

Nesse caso, Cordeiro (2010) ressalta que é necessário recordarmos que a história escolar dos alunos que entram por meio do sistema de cotas acontece nas escolas públicas. Bem sabemos que o ensino público vem apresentando nos últimos anos uma decadência na sua qualidade. Esse fator pode ser uma das justificavas das dificuldades dos alunos no que corresponde à assimilação e à compreensão do conhecimento oferecido pela universidade, visto que, muitos destacam, o ensino recebido na Educação Básica como fraco. Outro fator que leva esses estudantes a evadirem, “já massacrados pelos problemas financeiros, é a falta de ações pedagógicas específicas para promover o "nivelamento" dos alunos que apresentam dificuldades nos conteúdos básicos (pré-requisitos) para desenvolver os conteúdos das disciplinas" (CORDEIRO, 2010, p.111).

Os dados da tabela 6 nos possibilitam compreender que muitos alunos estão ingressando na UFG, mas o seu sucesso na carreira acadêmica não tem sido garantido, havendo desistência nos cursos devido a vários motivos. É fundamental entendermos que só o 
acesso não é suficiente, faz-se necessário cuidar das condições essenciais à vida acadêmica, (...) "dando possibilidade ao estudante de concluir no tempo regular, com a qualidade esperada, o curso no qual ingressou, pois caso contrário se poderá incorrer no erro de aumentar o contingente dos excluídos de dentro" (SANTOS M; SANTOS P, 2011 p.13).

Considerando que muitos alunos desistem do curso por causa das reprovações nas disciplinas, pretendemos averiguar como os estudantes que entraram pelo sistema de cotas estão se desenvolvendo nos cursos de licenciatura da UFG. Apresentaremos somente dois cursos: Letras e Pedagogia, pois não conseguimos obter informações sobre os outros cursos em relação a tal temática. Esses dados foram expostos no Seminário UFG/Inclui, em 2013.

O curso de licenciatura em Letras na Regional Goiânia fez uma comparação da média global por ação afirmativa desde o ano de 2009 a 2012. As médias dos alunos de escola pública foram 6,97; os negros de escola pública obtiveram 6,67; os indígenas alcançaram 6,76; e as dos alunos que não solicitaram as cotas foram 6,88 (PROGRAD, 2013). A média global dos alunos tem pouca discrepância, tendo ambos um desempenho considerável.

No que corresponde ao rendimento dos alunos que ingressaram pelo sistema universal e daqueles que ingressaram pelo sistema de cotas no ano de 2009 a 2012 no curso de pedagogia, não há uma diferença expressiva, como mostra o Gráfico 6:

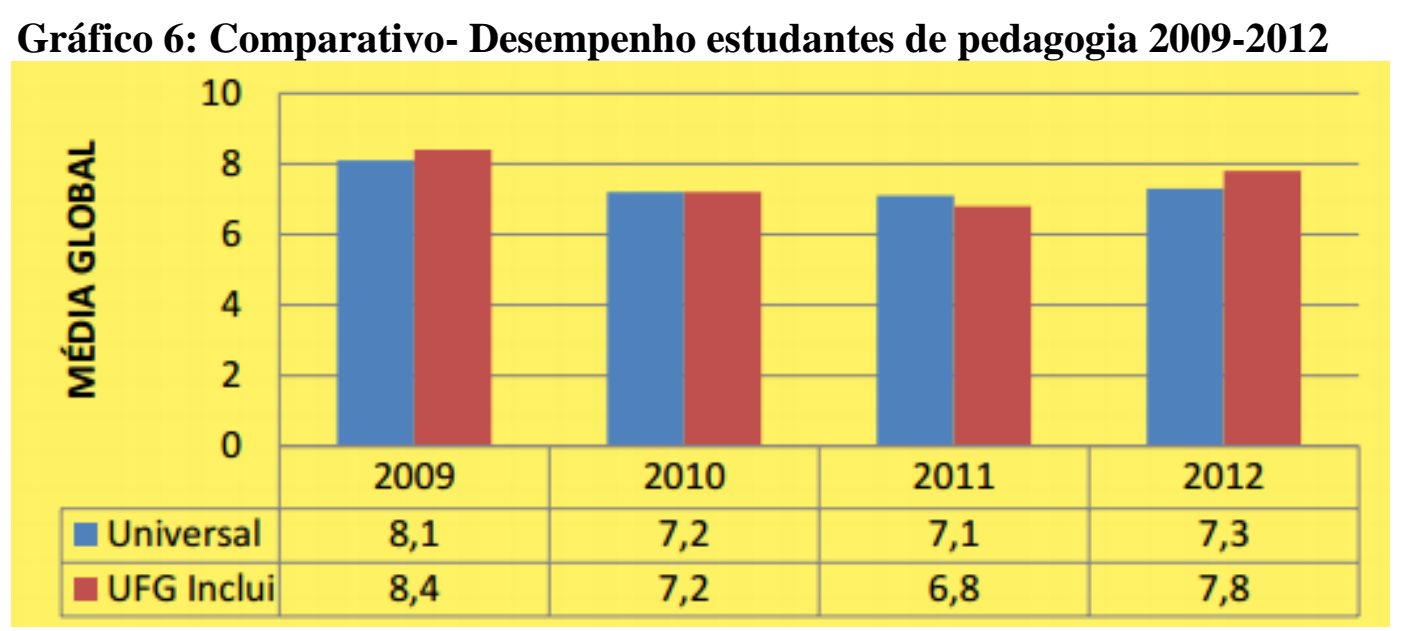

Fonte: Queiroz; Faria; Pereira; Andrade; Gabassa, 20132013. Site: http://www.prograd.ufg.br/pages/16214

A Faculdade de Educação Regional Goiânia trouxe outros fatores importantes em relação ao percurso acadêmico dos alunos provenientes do sistema de cotas, no ano de 2012: 65,9\% são oriundos de escola pública; $55,3 \%$ avaliam que o ensino médio não foi de qualidade; $63,5 \%$ dos alunos trabalham; $25 \%$ dos estudantes são do sistema de cotas e $18 \%$ são ingressantes pelo sistema universal; $80 \%$ dizem não ter dificuldade de permanecer na instituição; 96,5 declaram estar satisfeitos com o curso e 68,2\% têm um bom desempenho nas 
disciplinas. As dificuldades dos alunos perpassam pela questão econômica relacionada ao transporte e à conciliação entre trabalho e formação (QUEIROZ; FARIA; PEREIRA; ANDRADE; GABASSA, 2013, falta página).

No ano de 2013, a UFG buscou, por meio do Seminário ${ }^{15}$ UFG/Inclui, avaliar os cursos que aderiram ao programa UFG/Inclui. Entre os vários cursos desta universidade, daremos destaque aos cursos de licenciatura presenciais, sendo que somente alguns cursos participaram do seminário. São eles: Artes Cênicas, Ciências Sociais, Letras, Libras, Pedagogia e Música. O seminário apresentou dados importantes em relação à permanência dos alunos que pelo sistema de cotas no curso, tais como a desistência nos cursos de licenciatura. Os cursos não priorizam a questão da permanência dos alunos na instituição, somente o curso de Ciências Sociais aborda tal tema, mas, também, de maneira breve, promovendo reuniões com os estudantes do sistema de cotas com o compromisso de compreender e discutir as questões da permanência. A partir das reuniões, fica evidente que alguns estudantes não conhecem os programas de permanência ligados à UFG Regional Goiânia e ao programa UFG/Inclui. Nos cursos de Artes Cênicas e Música, o percentual de alunos ingressos pelo programa UFG/Inclui é baixo se comparado com os dos estudantes que entram por meio do sistema universal.

Com os dados apresentados até o momento, pode-se dizer que a UFG vem expandindo o acesso a grupos que, por vários anos, esteve fora das instituições de Educação Superior como os pretos, os indígenas, os quilombolas e outros. Mas observamos que o programa apresenta algumas lacunas, como a dificuldade de auxílio financeiro e apoio pedagógico aos estudantes do sistema de cotas. Isso fica evidente com os dados apresentados, pois, mesmo com a assistência estudantil, ainda há um índice considerável de alunos que evadem dos cursos de licenciatura.

Podemos dizer que, os cursos de licenciaturas da UFG Regional Goiânia vêm trabalhando as questões de acesso, desistência e desenvolvimento acadêmico dos alunos. No entanto, precisa reavaliar e reorganizar melhor suas ações para que as mesmas sejam coerentes com a realidade da instituição, garantindo o reconhecimento de cada indivíduo no que se refere às suas singularidades e capacidades, uma vez que o acesso é o ponto de partida de uma longa caminhada até chegar à conclusão do curso.

\footnotetext{
${ }^{15}$ O seminário UFG/Inclui é desenvolvido na UFG com o objetivo de analisar e discutir o programa de inclusão de estudantes oriundos de escolas públicas, negros estudantes de escolas públicas, indígenas e quilombolas. O evento traz dados referentes ao ingresso e à permanência na universidade e, além disso, avalia o desempenho dos estudantes, cuja finalidade é refletir sobre essas ações, visando a avaliação dos resultados e ao aprimoramento de ações que serão aplicadas futuramente.
} 


\section{A LUTA PELO RECONHECIMENTO E A FORMAÇÃO DE PROFESSORES}

Neste capítulo, buscaremos delinear a luta pelo reconhecimento seguindo as ideias de Axel Honneth, articulando-as com a formação de professores. Acreditamos que, para um aluno proveniente das cotas se realizar dentro dos cursos, é preciso que o outro o reconheça em suas singularidades e originalidade. É fundamental que a universidade ofereça não apenas o acesso, mas, também, condições para a sua formação docente e autorrealização. Através do reconhecimento do outro, ele apreende suas ações como pertencentes a sua própria pessoa.

\section{1. Vida e obra de Honneth}

Axel Honneth ${ }^{16}$ nasceu em 18 de julho de 1949, na cidade de Essen, no Estado da Renânia do Norte-Vestfália, ao oeste da Alemanha. Em 1983, ele apresentou a sua tese de doutoramento à Universidade Livre de Berlim, publicada em livro em 1985, sob o título Kritik der Macht (Crítica do Poder). No ano seguinte, tornou-se assistente de Jürgen Habermas, no Instituto de Filosofia da Universidade de Frankfurt. Nesta instituição, Honneth apresentou a sua tese de livre-docência: Luta por reconhecimento: a gramática moral dos conflitos sociais, publicada em 1996.

Atualmente é professor da Universidade de Frankfurt e diretor, desde 2001, do Instituto de Pesquisa Social, sediado na mesma cidade. Função essa desempenhada no decorrer da história do Instituto por Max Horkheimer, Theodor Adorno e Jürgen Habermas.

Axel Honneth faz parte da terceira geração da Escola de Frankfurt. Seus estudos estão voltados para o tema da intersubjetividade dos problemas da sociedade atual e o seu método de investigação corresponde às perspectivas teóricas e empíricas referentes à categoria reconhecimento: "no bojo de disciplinas como história, direito, sociologia e filosofia, em busca de uma categoria central contemporânea que possa definir de forma mais precisa situações de desrespeito e as consequências sociais advindas de tais experiências" (FUHRMANN, 2013, p. 84).

As obras de Axel Honneth estão publicadas na língua vernácula do autor. Há também alguns textos em espanhol, outros em inglês e francês. Dois de seus livros foram traduzidos para o português e alguns artigos em periódicos e coletâneas (FUHRMANN, 2013). Uma das

\footnotetext{
${ }^{16}$ Dados biográficos retirados do livro Luta por reconhecimento (2003).
} 
obras traduzidas para o português foi Luta por reconhecimento: a gramática moral dos conflitos sociais, em 2003, cujas ideias iremos abordar neste capítulo.

Além dessa obra, segundo Fuhrmann (2013), existem outras três importantes produções que nos aproximam do pensamento de Axel Honneth. É importante ressaltar que Honneth é um estudioso em plena produção científica, que continua publicando novas pesquisas, discussões e formulações em suas teorias. A primeira obra é a Crítica del Poder. Fases en la reflexión de una teoria crítica de la sociedad. Publicada em 1980, está dividida em dois capítulos. No primeiro, Honneth divaga nas obras de Horkheimer e Adorno, mostrando a diferença entre um pensamento tradicional e um pensamento crítico. Ele também destaca o déficit sociológico nas obras Teoria Tradicional e Teoria Crítica e Dialética da Ilustração. No segundo capítulo, o autor faz uma análise das contribuições de Foucault e Habermas à Teoria Crítica, resgatando as experiências dos indivíduos na sociedade industrial.

Outra obra deste autor, publicada em 2010, intitulada Ichimwir ${ }^{17}$, compõe-se de vários artigos: Paradoxien der Kapitalistischen Modernisierung. Ein Untersuchungsprogramm ${ }^{18}$, em coautoria com Martin Hartmann e Das Gewebe der Gerechtigkeit. Über die Grenzen des zeitgenössischen Prozeduralismus ${ }^{19}$. Em 2011, Honneth publica o livro Das Recht der Freiheit. Grundri $\beta$ einer demokratischen Sittlichkeit ${ }^{20}$. O livro tem três partes: na primeira, relata a história sobre o direito da liberdade. Na segunda, apresenta a liberdade jurídica e moral e, na terceira, discorre sobre a realidade da liberdade (FUHRMANN, 2013).

Trata-se de um dos principais pensadores alemães da atualidade, desenvolvendo e publicando vários estudos nas áreas da filosofia social, da política e da moral, dando destaque às relações de poder, reconhecimento e respeito.

\subsection{Luta por reconhecimento}

De acordo com Honneth (2003), para entendermos a sociedade contemporânea, é preciso apreender as lutas e conflitos dos grupos que necessitam de reconhecimento mútuo. A luta por reconhecimento é constante e inacabada, pois a todo instante buscamos ser reconhecidos. Para o autor, o reconhecimento:

\footnotetext{
${ }^{17}$ O Eu no Nós.

18 Paradoxos da Modernização Capitalista. Um programa de pesquisa.

${ }^{19}$ A Textura da Justiça. Sobre os limites do procedimentalismo.

${ }^{20}$ O Direito da Liberdade. Compêndio de uma eticidade democrática.
} 
[...] refere-se àquele passo cognitivo que uma consciência já constituída "idealmente" em totalidade efetuada no momento em que ela "se reconhece como a si mesma em uma outra totalidade, em uma outra consciência"; e há de ocorrer um conflito ou uma luta nessa experiência do reconhecer-se-nooutro, porque só através da violação recíproca de suas pretensões subjetivas os indivíduos podem adquirir um saber sobre se o outro se reconhece-se nele como uma totalidade (HONNETH, 2003, p. 63, grifo do autor).

O autor (2003) defende a ideia de que o reconhecimento pode levar os indivíduos ao autorreconhecimento em relação às suas capacidades e habilidades, proporcionando o autorrespeito, a autoestima e a autoconfiança, sendo essas as formas de se relacionar consigo mesmo e com o próximo, sendo que estes se configuram como o cerne da luta pela emancipação.

Honneth (2003), baseado nas teorias de Hegel, não considera as ideias de Maquiavel e Thomas Hobbes no que se refere à luta por autoconservação física ou por poder. Pois, para ele, o conflito é decorrente das experiências de desrespeito que afetam negativamente a identidade pessoal e coletiva. Nesse sentido, as lutas sociais não visam somente à autoconservação física como também ao reconhecimento recíproco. Segundo Honneth (2003, p.48):

[...] o conflito prático que se acende entre os sujeitos é por origem um acontecimento ético, na medida em que objetiva o reconhecimento intersubjetivo das dimensões da individualidade humana. Ou seja, um contrato entre os homens não finda o estado precário de uma luta por sobrevivência de todos contra todos, mas inversamente, a luta por um medium moral leva a uma etapa mais madura da relação ética.

A luta social pelo reconhecimento proporciona, enquanto força moral, o desenvolvimento do indivíduo, no que corresponde à sua vida social, sendo o mesmo reconhecido em sua singularidade. No entanto, a luta só será social a partir do momento em que ela deixar de ser particular e passar a ser coletiva. As experiências individuais de desrespeito são entendidas como experiências fundamentais, correspondentes a um grupo e não a intenções individuais, podendo, dessa maneira, influenciar na busca por relações ampliadas de reconhecimento (HONNETH, 2003).

Honneth (2003), embasado em Hegel, aponta três padrões de reconhecimento intersubjetivo: o amor, que permite ao sujeito ter confiança em si mesmo; o direito, que possibilita ao indivíduo ser reconhecido como membro da sociedade sendo protegido por determinados direitos; e a solidariedade, que proporciona ao sujeito se perceber como 
possuidor de capacidades e habilidades. É por meio desses padrões que os indivíduos se autorrealizam e se relacionam consigo mesmos e com outros, de forma positiva.

O amor é a primeira etapa do reconhecimento recíproco, sendo que, ao se efetivar, os sujeitos se admitem reciprocamente na natureza de suas carências. "Na experiência recíproca da dedicação amorosa, dois sujeitos se sabem unidos no fato de serem dependentes, em seu estado carencial, do respectivo outro" (HONNETH, 2003, p. 160). As carências e afetos somente se confirmam porque são correspondidos. Segundo Honneth (2003, p. 78), essa primeira forma de reconhecimento para Hegel é:

[...] concebida como uma relação de reconhecimento mútuo na qual a individualidade dos sujeitos encontra primeiramente confirmação; no entanto, aqui é atribuída essa determinação, ainda mais claramente do que antes, o significado, oriundo da teoria da subjetividade, de que só na própria experiência de ser amado o sujeito querente é capaz de experienciar-se a si mesmo pela primeira vez como um sujeito carente e desejante.

Para o autor (2003), o amor está ligado às emoções primárias. É a base da autoconfiança que permite ao sujeito se autorrealizar. Por meio dele, o sujeito se reconhece e se sente confirmado em sua natureza instintiva particular, permitindo o desenvolvimento da autoconfiança que o habilita a participar da formação política da vontade. O amor é um conhecimento mútuo, pois em sua efetivação há a confirmação recíproca dos indivíduos em relação à natureza de suas carências, reconhecendo-se, assim, como seres carentes. Logo, as carências e afetos:

[...] só podem de certo modo receber "confirmações" porque são diretamente satisfeitos ou correspondidos, o próprio reconhecimento deve possuir aqui o caráter de assentimento e encorajamento afetivo; nesse sentido, essa relação de reconhecimento está ligada de maneira necessária à existência corporal dos outros concretos, os quais demonstram entre si sentimentos de estima especial. A chave para transferir esse tema a um contexto de pesquisa determinado pelas ciências particulares é representada então por aquela formulação de Hegel segundo a qual o amor tem de ser concebido como um 'ser-si-mesmo em um outro'; pois, com isso, é dito das relações primárias efetivas que elas dependem de um equilíbrio precário entre autonomia e ligação, o qual constitui o interesse diretivo pela determinação das causas de desvios patológicos na teoria psicanalítica das relações de objeto (HONNETH, 2009, p. 160, grifo do autor).

Para compreender melhor o reconhecimento intersubjetivo, Honneth (2003) recorre às ideias de Winnicott, para quem o amadurecimento infantil acontecerá por meio da cooperação intersubjetiva de mãe e filho, sendo, assim, uma tarefa solucionada em comum. Tem-se como ponto inicial a simbiose, que ocorre assim que o bebê nasce, caracterizada por Winnicott 
como a "dependência absoluta", em que ambos os sujeitos dependem absolutamente um do outro. O filho depende da mãe para sobreviver e a mãe busca proteger a criança, dando assistência e cuidado. Ambos não se veem como um ser individual.

No entanto, para a mãe chegar a um termo, é preciso que tanto ela como o filho rompam com essa dependência. Dessa forma, a mãe ampliará o seu campo social e o filho apreenderá que a mãe faz parte do mundo, não estando sobre o seu domínio (HONNETH, 2003). A mãe volta à sua rotina e passa a interagir com outras pessoas. O filho, então: "sai da fase da "absoluta dependência", porque a própria dependência em relação à mãe entra em seu campo de visão, de modo que ele aprende agora a referir seus impulsos pessoais, propositadamente, a certos aspectos da assistência materna" (HONNETH, 2003, p. 167).

A segunda fase apresentada por Honneth (2003) é a "dependência relativa", em que a criança percebe que a mãe não pode estar à sua disposição em virtude de ter adquirido mais autonomia de ação. Nesta fase, a criança já é capaz de reconhecer o outro, considerando que o mesmo possui direitos próprios. Para obter a dependência, é preciso, segundo Winnicott apud Honneth (2003), apresentar dois mecanismos: o da "destruição" e o dos "fenômenos transicionais".

A destruição se caracteriza pelo fato de a criança utilizar de atos agressivos (mordidas, empurrões e golpe) contra a mãe. Isso se realiza porque a criança reconhece a independência e autonomia da mãe. Se a mãe suporta todos os atos agressivos sem nenhum tipo de ação, o filho passa a reconhecê-la como um ser de pretensões próprias, amando-a.

Nos fenômenos transicionais, a criança com poucos meses de vida estabelece uma relação afetiva com os objetos. Esses objetos transicionais (travesseiro, dedo polegar e brinquedo) são elos de mediação que se referem à fase de estar fundido e de estar separado. A partir do momento em que a criança fica sozinha com os objetos transicionais, ela desenvolve a sua criatividade infantil, "mesmo a faculdade de imaginação em geral está ligada ao pressuposto de uma 'capacidade de estar só', que por sua vez se realiza somente através da confiança elementar na disposição da pessoa amada para a dedicação" (HONNETH, 2003, p. 172,). Mesmo, sabendo que a mãe está distante, a criança tem confiança em sua dedicação. Logo: "a tese assim traçada fornece uma resposta acerca da espécie de autorrelação a que um sujeito pode chegar quando se sabe amado por uma pessoa vivenciada como independente, pela qual ele sente também, de sua parte, afeição e amor" (HONNETH, 2003, p. 173).

Ao abordar sobre o direito, Honneth (2003) diz que nos reconhecemos como pessoas de direito a partir do momento em que nos defrontamos com as obrigações que devemos ter em relação ao direito do outro e adquirimos também um saber em relação aos nossos direitos. 
Com isso, podemos estar convictos de que algumas de nossas pretensões serão realizadas. Nessa perspectiva, Hegel (apud HONNETH,) 2003, p.1790, expõe sobre o reconhecimento recíproco:

No estado, [...] o homem é reconhecido e tratado como ser racional, como livre, como pessoa; e o singular, por sua parte, se torna digno deste reconhecimento porque ele, com a superação da naturalidade de sua autoconsciência, obedece a um universal, à vontade sendo em si e para si, à lei, ou seja, se porta em relação aos outros de uma maneira universalmente válida, reconhece-os como o que ele próprio quer valer - como livre, como pessoa.

Desse modo, ao compreendermos o direito do outro, seremos capazes de nos perceber como sujeitos de direito, dotados de igualdade. As "pessoas de direitos só assumem a forma de reconhecimento do direito quando se tornam dependentes historicamente das peripécias dos princípios morais e universalistas” (HONNETH, 2013, p. 181).

$\mathrm{Na}$ sociedade tradicional, o reconhecimento jurídico se dava a partir da posição ou status que a pessoa ocupava na sociedade. Já na sociedade moderna, o sistema jurídico corresponde aos: "interesses universalizáveis de todos os membros da sociedade, de sorte que ele não admita mais, segundo uma pretensão, exceções e privilégios” (HONNETH, 2003, p. 181). Por conseguinte, os direitos são aplicados a todos de forma igual sem distinção ou discriminação.

Nesse percurso, ocorre um desacoplamento entre o reconhecimento jurídico e a estima social (status). Nas duas formas de reconhecimento, o homem é respeitado de acordo com as propriedades. "[...] mas no primeiro caso se trata daquela propriedade universal que faz dele uma pessoa; no segundo caso, pelo contrário, trata-se das propriedades particulares que o caracterizam diferentemente de outras pessoas" (HONNETH, 2003, p. 187). Com o rompimento, surge, então, a ideia de igualdade universal. Sendo assim:

[...] só com o desacoplamento entre as pretensões jurídicas individuais e as atribuições sociais ligadas ao status se origina o princípio de igualdade universal, que daí em diante vai submeter toda ordem jurídica ao postulado de não admitir mais, em princípio, exceções e privilégios. Uma vez que essa exigência se refere ao papel que o indivíduo detém como cidadão, com ela a ideia de igualdade assume ao mesmo tempo o significado de ser membro "com igual valor" de uma coletividade política: independentemente das diferenças no grau de disposição econômica, cabem a todo membro da sociedade todos os direitos que facultam o exercício igual dos seus interesses políticos (HONNETH, 2003, p. 190).

Nesse contexto, surgem duas formas de respeito, uma ligada ao reconhecimento jurídico, em “que todo ser humano deve ser considerado, sem distinção, um 'fim em si' [...] e 
a outra é o respeito social [...] que salienta o "valor" de um indivíduo, na medida em que este se mede intersubjetivamente pelos critérios da relevância social." O primeiro fato refere-se a um respeito universal; o segundo, às capacidades e às realizações individuais. O sujeito passa a ser respeitado no momento em que "encontra reconhecimento jurídico não só na capacidade abstrata de poder orientar-se por normas morais, mas também na propriedade concreta de merecer o nível de vida necessário para isso" (HONNETH, 2003, p. 184;193).

O direito tem como base os princípios morais, a igualdade estabelecida pela lei, não beneficiando somente alguns, mas todas as pessoas. A relação jurídica garante o autorrespeito pois: "a consciência de poder se respeitar a si próprio, porque merece o respeito de todos os outros" (HONNETH, 2003, p. 195). Nessa perspectiva:

[...] um sujeito é capaz de se considerar, na experiência do reconhecimento jurídico, como uma pessoa que partilha com todos os outros membros de sua coletividade as propriedades que capacitam para a participação numa formação discursiva da vontade; e a possibilidade de se referir positivamente a si mesmo desse modo é o que podemos chamar de "autorrespeito" (HONNETH, 2003, p. 197).

Outra esfera do reconhecimento é a solidariedade (ou eticidade). Essa terceira esfera, ao contrário do direito, que expressa as propriedades universais dos sujeitos, manifesta as diferenças de propriedade entre os sujeitos de forma universal. O indivíduo, além das duas formas já citadas de reconhecimento, precisa de uma estima social, que garanta a ele se referir positivamente em relação às suas capacidades e propriedades e que o qualifique em suas diferenças e não em suas igualdades. (HONNETH, 2003).

Para Honneth (2003, p. 209), o conceito de solidariedade pode ser compreendido como, diferentemente da forma moderna de reconhecimento jurídico uma estima social e:

[...] numa primeira aproximação, uma espécie de relação interativa em que os sujeitos tomam interesses reciprocamente por seus modos de vida, já que eles se estimam entre si de maneira simétrica. Essa proposta explica também a circunstância de o conceito de "solidariedade" se aplicar até o momento precipuamente às relações de grupo que se originam na experiência da resistência comum contra a repressão política; pois aqui é a concordância no objetivo prático, predominando sobre tudo, que gera de súbito um horizonte intersubjetivo de valores no qual cada um aprende a reconhecer em igual medida o significado das capacidades e propriedades do outro.

Na solidariedade, o reconhecimento se dá em relação à aceitação das qualidades individuais, de acordo com os valores já existentes na comunidade, o que permite o 
desenvolvimento da autoestima. A pessoa se sentirá valorizada a partir do momento em que as suas capacidades individuais não são mais avaliadas de maneira coletiva.

O conceito de estima para Honneth (2003) se caracteriza como a forma de o indivíduo singular buscar a boa vida. A estima social se refere às propriedades particulares "que caracterizam os seres humanos em suas diferenças pessoais: (...) requerendo um médium social que deve expressar as diferenças de propriedades entre sujeitos humanos de maneira universal, isto é, intersubjetivamente vinculante" (HONNETH, 2003, p. 199). A estima é determinada pelos critérios culturais de uma sociedade, pois suas capacidades e habilidades são julgadas pela intersubjetividade.

Assim, a solidariedade representa as relações sociais de estima simétrica entre sujeitos individualizados e autônomos com possibilidade de autorrealização. Essas relações sociais, na visão de Honneth (2003, p. 207), podem ser nomeadas como "solidárias", "porque elas não despertam somente a tolerância para com a particularidade individual da outra pessoa, mas também o interesse afetivo por essa particularidade" (HONNETH, 2003, p. 211). A relação simétrica ocorre quando os sujeitos conseguem notar que as suas propriedades e capacidades são valiosas para a sociedade, pela aceitação solidária. Segundo o autor: A estima se emprega de forma individual perante a universalidade, pois as
características individuais dos sujeitos passam a ser valorizadas e
reconhecidas. Com essa mudança a estima social não está mais vinculada a
quaisquer privilégios jurídicos e nem às qualidades morais da personalidade.
Podemos ainda ressaltar que "nas sociedades modernas as relações de estima
social estão sujeitas a uma luta permanente na qual os diversos grupos
procuram elevar, com os meios da força simbólica e em referência às
finalidades gerais, o valor das capacidades associadas à sua forma de vida".
(HONNETH, 2003, p. 207)

A desmoralização da solidariedade acontece devido às ofensas e às degradações, afetando a dignidade do indivíduo como sujeito de uma comunidade cultural de valores.

Quando tratamos da estima social, não devemos esquecer que esta, assim como o reconhecimento jurídico, passa por variações históricas e culturais. Honneth (2003) apresenta mudança da categoria de honra para as categorias reputação ou prestígio, na passagem das sociedades tradicionais para as sociedades modernas. A categoria de honra percebia a estima do sujeito de maneira coletiva, já nas segundas categorias, a estima se dá de forma individualizada. Com essa nova condição, o indivíduo pode experimentar o reconhecimento de suas qualidades e capacidades sem ter que passar por graduações coletivas. 
Com essa transição, a estima social não está mais vinculada a nenhum privilégio jurídico, desconsiderando dessa forma a caracterização de qualidades morais da personalidade. Agora ela passa a se referir ao: "grau de reconhecimento social que o indivíduo merece para sua forma de autorrealização, porque de algum modo contribui com ela à implementação prática dos objetivos da sociedade, abstratamente definidos." Essa forma individualizada do reconhecimento deriva: "de como se determina o horizonte universal de valores, que ao mesmo tempo deve estar aberto a formas distintas de autorrealização, mas que deve poder servir também como um sistema predominante de estima" (HONNETH, 2003, p. 2006).

Para Honneth (2003), o desrespeito é capaz de acabar com a identidade da pessoa, não lhe permitindo desenvolver a sua integridade e totalidade. Desse modo, motiva as lutas sociais, por meio das quais os sujeitos não reconhecidos buscam as interações intersubjetivas do reconhecimento. De acordo com o autor, a luta social refere-se:

[...] a processo prático no qual experiências individuais de desrespeito são interpretadas como experiências cruciais típicas de um grupo inteiro, de forma que elas podem influir como motivos diretores da ação, na exigência coletiva por relações ampliadas de reconhecimento (HONNETH, 2003, p. 257).

As lutas só são sociais a partir do momento em que geram objetivos que sejam coletivos. Na percepção de Axel Honneth (2003, p. 156), as lutas são: “[...] moralmente motivadas por grupos sociais, sua tentativa coletiva de estabelecer institucionalmente e culturalmente formas ampliadas de reconhecimento recíproco, aquilo que por meio do qual vem a se realizar a transformação normativamente gerida das sociedades.” Ou seja, trata-se de forças morais que favorecem o desenvolvimento social. Com isso, não são possíveis conflitos sociais voltados totalmente para o amor, sendo este a forma mais elementar do reconhecimento, porque as experiências morais individuais não podem formar conflitos sociais, mas somente vivências particulares. Esse fato não ocorre com o direito e com a estima social, pois os mesmos já possuem um cenário moral de conflitos sociais por dependerem de critérios generalizados socialmente.

As lutas só podem ser concretizadas por ideias e exigências gerais em que as experiências individuais de desrespeitos são superadas, devendo haver uma ponte semântica no que se refere: "[...] às finalidades impessoais de um movimento social e às experiências privadas que seus membros têm da lesão", de forma a assegurar a formação de uma identidade coletiva. Para os movimentos sociais, é necessária a "existência de uma semântica 
coletiva que permite interpretar as experiências de desapontamento pessoal como algo que afeta não só o eu individual, mas também um círculo de muitos outros sujeitos." Portanto, as experiências de desrespeito que eram particulares e privadas podem se transformar em uma "luta coletiva por reconhecimento" (HONNETH, 2003, p. 258). Nesse sentido, por meio da resistência comum, os indivíduos serão capazes de se conscientizarem do seu próprio valor social e moral, percebendo-se como seres autônomos e individuados.

As atitudes referentes ao desrespeito e à ofensa, que são formas de reconhecimento recusado, podem gerar consequências negativas, como uma profunda lesão psíquica no indivíduo, além de provocar danos à liberdade, à identidade e à integridade, desestruturando a sua autorrelação prática e seu êxito nos processos de socialização.

Segundo Honneth (2003), há três formas de desrespeito que podem prejudicar a autorrelação prática, causando a privação do indivíduo quanto ao reconhecimento, à vida boa e ao desenvolvimento pleno de sua identidade pessoal. A primeira forma é a tortura, que tem como consequência a falta de autonomia corporal, impedindo a pessoa de dispor de seu corpo livremente, imputando-lhe dor física, humilhação e vergonha perante a sociedade. Com o passar do tempo, essa forma de desrespeito se transforma em perda da autoconfiança que resulta do amor e que possui a competência de operar o próprio corpo de maneira autônoma. Logo, o sujeito perde a confiança que tinha de si e do mundo, tornando-se uma pessoa insegura. Para Honneth (2003), a tortura não varia com o contexto social e nem com as questões culturais. Segundo ele:

[...] toda tentativa de se apoderar do corpo de uma pessoa, empreendida contra a sua vontade e com qualquer intenção que seja, provoca um grau de humilhação que interfere destrutivamente na autorrelação prática de um ser humano, com mais profundidade do que outras formas de desrespeito; pois a particularidade dos modos de lesão física, como ocorrem na tortura ou na violação, não é constituída, como se sabe, pela dor puramente corporal, mas por sua ligação com o sentimento de estar sujeito à vontade de um outro, sem proteção, chegando a perda do senso de realidade. (HONNETH, 2003, p. 215)

A segunda forma de desrespeito é a negação do direito. O indivíduo perde o direito de ser reconhecido como igual na sociedade, que não lhe oferece condições igualitárias. Dessa forma o sujeito passa a não conseguir se imaginar como pessoa com condições iguais aos de seus parceiros de interação. Isso porque: “[...] para o indivíduo, a denegação de pretensões jurídicas socialmente vigentes significa ser lesado na expectativa intersubjetiva de ser 
reconhecido como sujeito capaz de formar juízo moral" (HONNETH, 2003, p. 216). Ou seja, retira-se dele a sua competência julgadora.

A última forma de desrespeito é a degradação do estilo de vida individual ou grupal, em que a pessoa não consegue mais ver suas características e propriedades como algo que tem representação na sociedade em que vive, ficando estremecida a sua autoestima, não se sentindo estimado em suas particularidades. É nesse momento que o indivíduo experimenta as ações de ofensas e degradações. "Portanto, o que é subtraído da pessoa pelo desrespeito em termos de reconhecimento é o assentimento social a uma forma de autorrealização que ela encontrou arduamente como encorajamento baseado em solidariedade de grupos" (HONNETH, 2003, p. 218).

As três formas de desrespeito poderão motivar os sujeitos a lutarem por seu reconhecimento, pois:

[...] os sujeitos humanos não podem reagir de modo emocionalmente neutro às ofensas sociais, representadas pelos maus-tratos físicos, pela privação de direitos e pela degradação, os padrões normativos do reconhecimento recíproco têm uma certa possibilidade de realização no interior do mundo da vida social em geral; pois toda reação emocional negativa que vai de par com a experiência de um desrespeito de pretensões de reconhecimento contém novamente em si a possibilidade de que a injustiça infligida ao sujeito se lhe revele em termos cognitivos e se torne o motivo da resistência política (HONNETH, 2003, p. 224).

Para Honneth as: "experiências individuais de desrespeito são interpretadas como experiências cruciais típicas de um grupo inteiro, de forma que elas podem influir como motivos diretos da ação, na exigência coletiva por relações ampliadas de reconhecimento" (HONNETH, 2003, p. 257), que impulsionam o desenvolvimento social. Segundo o autor, é por meio de conflitos que acontece o desenvolvimento moral da sociedade e dos sujeitos, ampliando as relações de reconhecimento.

Portanto, um dos pontos centrais da ideia de Honneth é que:

[...] todos os confrontos sociais e todas as formas de conflito seriam constituídos em princípio segundo o mesmo modelo de uma luta por reconhecimento: nesse caso, todo ato coletivo de resistência e rebelião seria atribuído, segundo sua origem, a um quadro invariante de experiências morais, dentro do qual a realidade social é interpretada conforme uma gramática historicamente cambiante de reconhecimento e respeito. (HONNETH, 2003, p. 260)

Como já foi apresentado antes, de acordo com Honneth (2003), quando o indivíduo não é reconhecido pelo outro, ele não consegue ter um pensamento positivo para com ele 
mesmo. Esse fato logo provoca a luta por relações intersubjetivas do reconhecimento. Entretanto, os conflitos surgem a partir das experiências de desrespeito (violação e maus tratos, privação de direito, exclusão, degradação e ofensas).

Em síntese, para a formação da identidade do indivíduo é necessário que ele seja reconhecido intersubjetivamente. Esse reconhecimento ocorrerá de três formas: o amor que gera a autoconfiança; o direito que se refere ao autorrespeito; e a solidariedade que corresponde à constituição da autoestima. A ruptura dessas dimensões por meio do desrespeito do outro provoca as lutas sociais, pois o sujeito buscará as relações intersubjetivas de reconhecimento. São três as formas de desrespeito: a tortura, a privação do direito e a solidariedade.

Ao refletimos sobre a luta pelo reconhecimento na discussão sobre o sistema de cotas, entendemos que o reconhecimento das particularidades e originalidade dos sujeitos que por muitos anos foram excluídos, discriminados e marginalizados da Educação Superior devido a vários fatores como as condições socioeconômicas, raciais e étnicas é um fator importante a ser considerado. Defendemos a ideia de que tal política afirmativa deve estar atenta a necessidade de reconhecimento do outro durante todo o processo formativo, promovendo a autovalorização desses alunos na profissão.

Compartilhamos com Honneth de que é pelo direito que os sujeitos se reconhecem reciprocamente como pessoas dotadas de igualdade. Assim: “obedecendo à mesma lei, os sujeitos de direito se reconhecem reciprocamente como pessoas capazes de decidir com autonomia individual sobre normas individuais" (HONNETH, 2003, p. 182). A negação do direito compromete o autorrespeito, uma vez que a pessoa não é reconhecida como capaz. Com isso, a pessoa se percebe inferior moralmente, tornando-se incapaz de se reconhecer frente ao outro. Nesse sentido é que a política de cotas na universidade deve prestar atenção no estudante em sua singularidade, proporcionando o autorrespeito, a autoestima e a autoconfiança, permitindo que ele relacione consigo mesmo e com o próximo de forma positiva.

Diante dessa preocupação é que entendemos que as políticas de cotas apresentam lacunas das quais precisam ser reparadas, pois o acesso não é garantia de inclusão e muito menos de reconhecimento. Esse fator pode repercutir de forma negativa na formação acadêmica desses que acabam não se realizando nos cursos e na profissão docente. Como já abordado as experiências de desrespeito ou não reconhecimento impossibilitarão a realização do sujeito em sua integralidade, consequentemente não se referirá a si mesmo como ser de 
capacidades e habilidades, não sendo possível, portanto o desenvolvimento de sua totalidade e integridade.

Nas sociedades modernas, as relações de estima sociais podem enfrentar lutas constantes, em que diferentes grupos procuram elevar através de estrutura simbólica o valor das capacidades vinculadas à sua forma de vida. Portanto, o que determina o desfecho dessas lutas, "estabilizado apenas temporariamente, não é apenas o poder de dispor dos meios da força simbólica, específico de determinados grupos, mas também o clima, dificilmente influenciado, das atenções públicas” (HONNETH, 2003, p. 207).

\subsection{Formação docente nos cursos de licenciatura}

A formação inicial do professor deve ocorrer preferencialmente no âmbito da universidade, uma vez que esse meio é o que melhor favorece ao aluno o desenvolvimento de sua trajetória, construindo coletivamente a sua aprendizagem do ser professor e pesquisador. Segundo Brzezinski: "a formação inicial é uma forma rigorosa de pensar, refletir, criar, enfim, apreender e socializar o conhecimento já acumulado pela humanidade” (2008, p. 1.142) produzindo não só o saber pedagógico e político da ciência, mas também como forma de engendrar novos conhecimentos de um campo específico do seu interesse. Essa formação tem um papel essencial no que corresponde ao desenvolvimento profissional do educador e também na construção de sua identidade, influenciando positivamente na articulação teoria e prática, dando condições ao mesmo de exercer com autonomia e confiança o seu trabalho, uma vez que este é o mediador do conhecimento e formador de cidadãos.

Um grande marco na história da formação de professores foi a Lei de Diretrizes e Base da Educação Nacional (LDB) $n^{\circ}$ 9394/96, que possui um título sobre a formação de professores, sendo um de seus destaques a importância da formação no espaço universitário. Em seu artigo 62 propõe que a formação docente para atuar na Educação Básica deve ocorrer em nível superior, em curso de licenciatura, de graduação plena, em institutos e universidades, “admitida, como formação mínima para o exercício do magistério na educação infantil e nos 5 (cinco) primeiros anos do ensino fundamental, a oferecida em nível médio na modalidade normal."

É importante compreendermos que as instituições educativas no decorrer do século XX passaram por inúmeras transformações, mas, ainda assim não conseguiram romper totalmente com algumas de suas características iniciais: centralista, transmissora, 
selecionadora, individualista, entre outras (IMBERNÓN, 2011). Dessa forma a universidade precisa desfazer-se dessas características proporcionando uma formação que garanta aos estudantes espaços de participação, reflexão e crítica, abrindo caminhos para uma autonomia profissional, não sendo somente: "mera transmissora de conhecimentos acadêmicos, de onde de fato provém, e que se tornou inteiramente obsoleta para a educação dos futuros cidadãos em uma sociedade democrática: plural, participativa, solidária, integradora..." (IMBERNÓN, 2011 p. 7).

Com base em Imbernón (2011), podemos afirmar que a universidade tem o papel de produzir e disseminar conhecimentos e práticas que asseguram aos estudantes o preparo teórico, as habilidades na hora de realizar o seu trabalho e uma emancipação profissional, para além de uma visão rotineira, técnica da profissão. Tais conhecimentos capacitam o docente a exercer o processo educativo: [...] "em toda a sua complexidade, atuando reflexivamente com a flexibilidade e rigor necessário, isto é, apoiando suas ações em uma fundamentação válida para evitar cair no paradoxo de ensinar a não ensinar". (IMBERNÓN, 2011, p. 63)

Além de considerar esses fatores abordados por Imbernón (2011), é fundamental que as instituições de Educação Superior criem mecanismos para que a cultura, os conhecimentos e as tradições dos alunos sejam partilhados, com o objetivo de romper com as ações pedagógicas que não visem ao reconhecimento das singularidades e capacidades dos mesmos. Ao apreendermos a universidade como lócus de formação, buscamos referendá-la como fundamental para a formação docente, indispensável para prática pedagógica e também para a aquisição de um saber consolidado. Nessa perspectiva, Imbernón assegura ser "preciso estabelecer um preparo que proporcione um conhecimento válido e gere uma atitude interativa e dialética" [...] (IMBERNÓN, 2011, p. 63); a criar estratégias e métodos de intervenção, cooperação, análise, reflexão; a construir um estilo rigoroso e investigativo". O autor afirma que a formação deve ultrapassar o ensino de uma simples atualização científica, pedagógica e didática, proporcionando um espaço de participação, reflexão e formação que permita aos professores e futuros professores lidar com as mudanças e incertezas. Ou seja:

[...] o processo de formação deve dotar os professores de conhecimentos, habilidades e atitudes para desenvolver profissionais reflexivos ou investigadores. Nesta linha, o eixo fundamental do currículo de formação de professor é o desenvolvimento da capacidade de refletir sobre a própria prática docente, com o objetivo de aprender a interpretar, compreender e refletir sobre a realidade social e a docência (IMBERNÓN, 2011, p. 41 e 42).

Dentro desse contexto, Imbernón (2011) salienta que a formação se dá em diferentes momentos e aponta quatro desses: o primeiro é a experiência como discente, em que há uma 
relação das concepções e crenças que se referem à atividade docente, que os futuros professores trazem da vivência como aluno; o segundo é denominado de socialização, que consiste no conhecimento profissional, sendo construído na formação inicial específica; o terceiro corresponde à vivência profissional, período de iniciação à docência, que ocorre no campo da prática educacional que permite a concretização de um determinado conhecimento profissional; e o quarto diz respeito à formação permanente, em que se questiona ou legitima o conhecimento profissional posto em prática.

As instituições de Educação Superior devem levar em consideração esses aspectos, garantindo a todos uma formação comprometida com o reconhecimento, a autonomia, a reflexão, as práticas coletivas, o desenvolvimento dos saberes teóricos e práticos, tendo em vista a formação de professores socialmente críticos e pesquisadores, conscientes do papel que a educação tem para a sociedade. Nóvoa (1992, p.25) afirma que a formação:

[...] deve estimular uma perspectiva crítico-reflexivo, que forneça aos professores os meios de um pensamento autônomo e que facilite as dinâmicas de autoformação participada. Estar em formação implica um investimento pessoal, um trabalho livre e criativo sobre os percursos e os projetos próprios, com vista à construção de uma identidade, que é também uma identidade profissional.

Concordamos que a formação deva ir além da transmissão de conteúdos, formando, assim, professores críticos e reflexivos, que não sejam somente reprodutores do conhecimento. Que tal formação propicie também aos estudantes o desenvolvimento de um pensamento autônomo, que permita autoformação participativa, assumindo um trabalho livre e criativo no decorrer de toda a sua trajetória acadêmica e profissional, no intuito de construir uma identidade profissional docente.

Mas é valido ressaltar que a formação para Nóvoa (1992) não se dá por acumulação de vários cursos, conhecimentos ou até mesmo técnicas. Ela acontece em um processo de reflexão crítica sobre as ações e também pela (re)construção constante da identidade pessoal. “Os momentos de balanço retrospectivo sobre os percursos pessoais e profissionais são momentos em que cada um produz a (sua) vida, o que no caso dos professores é também produzir a (sua) profissão" (NÓVOA, 1992, p. 26). A reflexão permite ao professor aperfeiçoar o trabalho docente e rever suas concepções concernentes à teoria e à prática, ao ensino e à aprendizagem, possibilitando-lhe, assim, ir além da repetição e reprodução de ideias e práticas distante da nossa realidade, rompendo com os modelos tecnicistas. 
Desse modo, os professores serão capazes de revisar, criticar e criar a sua própria prática, promovendo mudanças no contexto educacional e social do qual fazem parte. Para isso, é necessário, como aborda Nóvoa, apreciar paradigmas de formação que estejam voltados à: "preparação de professores reflexivos, que assumam a responsabilidade do seu próprio desenvolvimento profissional e que participem como protagonista na implementação das políticas educativas" (NÓVOA, 1992, p. 27). A formação visada é aquela comprometida em garantir aos professores a capacidade de produzir e socializar os seus conhecimentos de forma autônoma, tornando-se autores de suas ações e decisões, construindo novas propostas para a educação, em um processo coletivo e de interação.

Ao focarmos o nosso olhar no contexto da formação de professores, devemos retratar a questão da identidade docente. Lembrando que essa, de acordo com Nóvoa: “[...] não é um dado adquirido, não é uma propriedade, não é um produto. A identidade é um lugar de lutas e de conflito, é um espaço de construção de maneiras de ser e de estar na profissão", que nos permite executar com autonomia as nossas ações. "Lembrando que o processo indenitário passa também pela capacidade de exercermos com autonomia a nossa atividade, pelo sentimento de que controlamos o nosso trabalho" (NÓVOA, 1999 p.16 e 17).

Para Nóvoa (1999), a identidade requer tempo para refazer identidades, adaptar a inovações e assimilar mudanças. Pois essa é construída no decorrer de todo o percurso pessoal e profissional, não é algo finalizado, requer continuidade ao longo da vida, estando em constante renovação, uma vez que a formação está relacionada com o contexto e momento histórico da sociedade. $\mathrm{O}$ autor ainda aponta que há três AAA que dão suporte à formação de professores:

- A de Adesão, porque ser professor implica sempre a adesão a princípios e a valores, a adaptação de projetos, um investimento positivo nas potencialidades das crianças e dos jovens.

- A de Ação, porque também aqui, na escolha das melhores maneiras de agir, se jogam decisões do foro profissional e do foro pessoal. Todos sabemos que certas técnicas e métodos "colam" melhor com a nossa maneira de ser do que dos outros. Todos sabemos que o sucesso ou o insucesso de certas experiências "marcam" a nossa postura pedagógica, fazendo-nos sentir bem ou mal com esta ou aquela maneira de trabalhar na sala de aula.

- A de Autoconsciência, porque em última análise tudo se decide no processo de reflexão que o professor leva a cabo sobre a sua própria ação. É uma dimensão decisiva da profissão docente, na medida em que a mudança e a inovação pedagógica estão intimamente dependentes deste pensamento reflexivo (NÓVOA, 1999, p. 16). 
A identidade é um processo em constante transformação, não sendo adquirida, mas sim construída. Esses elementos permitem ao professor aderir a projetos, a princípios e valores; fazer as escolhas certas e, além disso, refletir sobre tais escolhas.

Já para Brzezinski (2008), a identidade pode se dar de duas formas: a) pessoal, que engloba a história e a experiência pessoal, provocando um sentimento de unidade e b) coletiva, sendo esta uma construção social, que vai se caracterizando nos grupos e nas categorias que dão base à sociedade, dando, portanto, ao indivíduo, um papel e um status social. A autora cita Castelles (1999) para enfatizar que tanto na identidade pessoal como na coletiva os elementos que compõem a sua construção são processados pelos sujeitos e pelos grupos sociais, e que ambos reestruturam os significados de acordo com os preceitos sociais e também com os projetos culturais, impregnados na sociedade. Consequentemente, para que algo seja coletivo ou social, é preciso a vivência do subjetivo e do objetivo.

A identidade profissional se configura como identidade coletiva: [...] "que se desenha de dentro para fora de sua categoria profissional ou, [...] trata-se de identidade profissional edificada pelos professores na interação entre o microcosmos da escola e o macrocosmo da sociedade” (BRZEZINSKI, 2002, p.19, grifos da autora). Ou seja, a identidade vai sendo formada em um processo coletivo, por meio das interações sociais que os sujeitos vão estabelecendo com seus pares. Notando que: "as transformações que vão ocorrendo por toda a vida dos professores poderão levá-los a atingir condições ideais que garantam um exercício profissional de qualidade" (BRZEZINSKI, 2002, p. 10).

Dando ênfase à questão da identidade, Brzezinski (2002 p. 8), concordando com Castells (1999), afirma que a identidade é uma fonte de significado e experiência de um povo. Desse modo, o "processo de construção de significado e experiência dá-se com base em atributos culturais que se inter-relacionam e que são inerentes a uma determinada sociedade e circunscrita ao espaço e tempo históricos".

Ao se falar da formação de professores é importante destacarmos um fenômeno que vem se manifestando na carreira docente que é o mal estar docente. Esse fator é decorrente das condições precárias de trabalho a que vêm sendo submetidos os professores, produzindo, entre outros fatores, acentuada desvalorização do magistério, crescente desistência da profissão pelos professores e evasão dos possíveis candidatos ao magistério.

Percebemos que a realidade da formação docente é pouco atraente. Nos vestibulares, as inscrições no que se refere à docência são mínimas. Além disso, há questões decorrentes das políticas, que dificultam ao professor exercer sua autonomia didática, estabelecem um excesso de conteúdos e descuidam do espaço físico onde o professor e alunos realizam suas 
tarefas. Acrescentem-se a isso os salários baixos, os estresses e as doenças profissionais.

Para Esteve (1999, p.25), o mal estar “descreve os efeitos permanentes de caráter negativo que afetam a personalidade do professor como resultado das condições psicológicas e sociais em que se exerce a docência". Segundo Jesus (2002) o que leva ao mal-estar docente são as cobranças feitas pela política em relação ao trabalho do professor, as mudanças ocorridas na dinâmica das famílias, o desenvolvimento tecnológico e a massificação do ensino.

A formação pode desencadear elementos para construção de uma identidade profissional que eleve a autoconfiança e expectativa de sucesso dos futuros professores, mantendo-os no propósito de exercício da profissão. Para isso, é preciso uma formação que permita a construção da autonomia, pelo exercício da crítica e da reflexão, bem como da emancipação, e que garanta também o bem estar integral, físico, psíquico e social da pessoa.

Neste sentido, a formação de professores deve ser mais um processo de "tornar-se" do que apenas obter informações sobre como ensinar. Noutros termos, a formação de professores começa a ser cada vez mais entendida como um processo de descoberta e de desenvolvimento pessoal do que como um mero processo de ensinar como ensinar. (JESUS, 2002, p. 31).

Enfim, a formação deve proporcionar aos educadores a ampliação dos seus conhecimentos e a construção de sua identidade, por meio de um processo individual e coletivo, no qual suas particularidades e diferenças sejam reconhecidas. Ou seja, a formação deve ir além das formas mecanicistas e conteudistas, formando sujeitos críticos e reflexivos, autores de suas ações e decisões. 


\section{O RECONHECIMENTO DOS ALUNOS DE LICENCIATURA PRESENCIAL DA UFG QUE ENTRAM PELO SISTEMA DE COTAS}

Neste capítulo, buscaremos apresentar como o reconhecimento dentro da universidade pode influenciar na realização profissional dos alunos dos cursos de licenciatura que entraram pelo sistema de cotas. Para tanto, aplicamos dois questionários ${ }^{21}$, um para os coordenadores e outro para os alunos dos cursos de licenciatura da UFG Regional Goiânia que entraram pelo sistema de cotas.

O primeiro questionário foi elaborado no encuestafacil (site: www.encuestafacil.com) e enviado por e-mail para os coordenadores dos dezoito cursos de licenciatura presenciais da UFG Regional Goiânia, contendo um total de dezesseis perguntas abertas e fechadas. O segundo questionário foi enviado para os alunos desses mesmos cursos, com 21 questões abertas e fechadas. Devido ao número expressivo de estudantes (806), selecionamos aleatoriamente quatro de cada curso totalizando 72. Os coordenadores e os alunos foram convidados a participar da pesquisa por meio de seus e-mails que foram disponibilizados pela PROGRAD-UFG.

Algumas dificuldades foram encontradas nesse percurso. Enviamos para todos os coordenadores dos cursos de licenciatura presenciais o questionário em anexo e, após dois meses, somente um coordenador havia respondido. Diante dessa realidade, reenviamos o questionário, mas não obtivemos sucesso. Sendo assim, decidimos ir à universidade e conversar com os coordenadores pessoalmente para explicar a importância da pesquisa e das suas colaborações. Nesta visita, encontramos alguns coordenadores receptíveis, outros menos. Depois da visita, o questionário ficou aberto por mais quatro meses. Ao final de quatro meses do questionário aberto, obtivemos nove questionários respondidos do total de dezoito, sendo que nem todos os coordenadores responderam ao questionário na sua integralidade.

Com os alunos também encontramos a mesma dificuldade; poucos alunos responderam ao questionário. Reenviamos o questionário várias vezes e também o deixamos aberto por três meses na busca de conseguir mais informações, mas, mesmo assim, dos 72 questionários obtivemos somente quinze respostas, sendo que nem todos responderam ao questionário na sua totalidade. Talvez a pequena quantidade de respondentes se deva a sensibilidade da temática.

\footnotetext{
${ }^{21}$ No decorrer deste capítulo quando nos referirmos ao questionário dos coordenadores usaremos o número 1 e para o questionário dos alunos do sistema de cotas o número 2.
} 


\subsection{A percepção dos coordenadores}

De início elaboramos um questionário para os coordenadores ${ }^{22}$ com a finalidade de compreender melhor o objeto estudado. Ou seja, certificar como se dá o processo de inclusão dos alunos do sistema de cotas dentro dos cursos e se esses promovem alguma ação de assistência estudantil.

Buscamos compreender como é o desempenho dos estudantes provenientes do sistema de cotas na visão dos coordenadores. O ingresso, segundo Sousa e Portes: "não é sinônimo de permanência, e esta não é sinônimo de sucesso escolar e de bons rendimentos" (SOUZA E PORTES, 2011, p. 528). Ou seja, não basta receber o aluno do sistema de cotas, mas, sim, proporcionar a ele oportunidades para que seja reconhecido em suas potencialidades e capacidades.

Perguntamos aos coordenadores como era o desempenho do aluno proveniente do sistema de cotas no curso. Dos nove coordenadores, somente dois não responderam. Com o gráfico 7, percebemos que o desenvolvimento desses estudantes para $71 \%$ é bom e para $29 \%$, regular.

\section{Gráfico 7: Questão 14 - (Como é o desempenho dos alunos que entram por meio do sistema de cotas no curso?)}

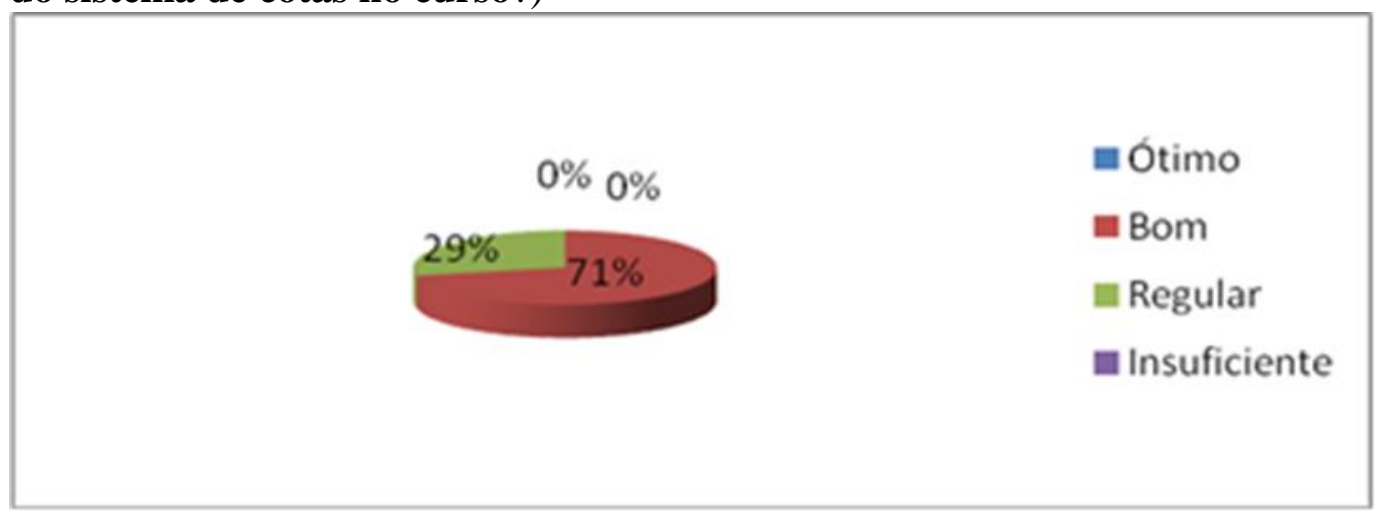

Fonte: Dados da pesquisa

Segundo os coordenadores são poucos os alunos do sistema de cotas que apresentam dificuldades referentes ao ensino e a aprendizagem. Mas, infelizmente o preconceito está impregnado em nossa sociedade e esse fato não é diferente dentro da universidade. Pois com a efetivação da política de cotas surgem comentários negativos e positivos sobre o assunto por parte da sociedade civil e acadêmica. Alguns acreditam que a entrada dos alunos por meio

\footnotetext{
${ }^{22}$ É importante destacarmos que nem sempre os coordenadores de curso sabem quem são os alunos que entram por meio do sistema de cotas.
} 
deste sistema pode causar baixo desempenho na qualidade de ensino. Mas os dados nos mostram uma visão contrária a esse pensamento, pois, observamos no Gráfico 7, que o desenvolvimento dos estudantes do sistema de cotas prevalece entre bom e regular. Não há, portanto, segundo os coordenadores, a desqualificação dos cursos em decorrência da entrada destes na instituição.

Velloso (2009) desconstrói esse pensamento, por meio de uma pesquisa realizada na Universidade de Brasília (UnB) com os alunos que ingressaram nos anos de 2004 a 2006, pelo sistema de cotas e pelo tradicional, buscando abordar o rendimento dos estudantes. Foram comparadas as notas dos alunos do sistema de cotas e as dos alunos do sistema universal, das áreas de humanas, ciências e saúde. A pesquisa teve como resultado que dois terços das carreiras não obtiveram diferenças significativas em relação às médias.

Perguntamos também aos coordenadores quais eram as dificuldades do curso no acolhimento dos alunos do sistema de cotas. Foram apresentadas várias alternativas das quais eles deveriam escolher uma. Caso optassem por outra, pedimos que justificassem a resposta.

Tabela7: Questão 13 - (Quais são as dificuldades do curso no acolhimento dos alunos do sistema de cotas? Se considerar necessário marque mais de uma alternativa?)

\begin{tabular}{lrr}
\hline Dificuldades & $\mathbf{N}^{\circ}$ de resposta & \% de resposta \\
\hline Estrutura física & 0 & $0 \%$ \\
Falta de recursos & 0 & $0 \%$ \\
Diversidade dos alunos & 1 & $14 \%$ \\
O baixo desempenho dos alunos cotistas & 0 & $0 \%$ \\
A formação dos professores & 0 & $0 \%$ \\
O preconceito da comunidade acadêmica em & & \\
relação aos cotistas & 0 & $8 \%$ \\
Outra (Por favor especifique) & 6 & \\
\hline Total & 7 & \\
\hline
\end{tabular}

Fonte: Dados da pesquisa

Apenas um coordenador relatou que a dificuldade de acolhimento dos estudantes do sistema de cotas é devido à diferença. Podemos notar que o perfil dos alunos da UFG se torna cada vez mais heterogêneo e diversificado com o sistema de cotas, exigindo dessa forma ações pedagógicas que considere e valorize as particularidades desses acadêmicos, proporcionando um ambiente mais inclusivo. Pois, quando as práticas pedagógicas não atendem à realidade e às necessidades dos sujeitos, o baixo desenvolvimento acadêmico ou até mesmo o abandono do curso tem mais chances de acontecer.

Diante do exposto, entendemos a relevância de se trabalhar com a realidade dos estudantes, considerando seus conhecimentos prévios, experiências e opiniões e suas 
particularidades, pois são oriundos de vários contextos culturais e caracterizam diversos segmentos sociais, não sendo iguais e nem homogêneos. Além disso, é fundamental, de acordo com Nóvoa (1992), proporcionar aos alunos o desenvolvimento de um pensamento autônomo e reflexivo, sendo autores de suas próprias ações, construindo, assim, a sua identidade profissional docente em um processo coletivo. Ou seja, a construção da identidade se dá em um processo de lutas e conflitos, não é algo pronto e acabado, ocorrendo em todo o percurso pessoal e profissional.

Para Honneth (2003), a formação da identidade depende das três formas de reconhecimento: a autoestima que propicia aos indivíduos perceber as suas habilidades como algo importante para a sociedade; o autorrespeito, pelo qual o sujeito é reconhecido como membro da sociedade, sendo resguardado por determinados direitos; e a autoconfiança do sujeito. Por meio dessas três esferas, o indivíduo é capaz de desenvolver autorrelação prática positivamente. Desse modo, os professores ao se reconhecerem como seres capazes de produzir suas ações frente ao outro, desenvolverão um trabalho com qualidade, respeitando a singularidade e a originalidade de seus alunos.

Considerando ainda a questão 13, os demais coordenadores optaram pela opção “outros". Ao escolher a opção "outros”, solicitamos a eles que especificassem suas respostas.

\section{Quadro 4: Questão 14 (Justificativa)}

- Não há dificuldade, pois não há essa diferenciação.

- Não há dificuldades, pois não há conhecimento de quem é os estudantes provenientes das cotas.

- Isto ainda não foi tratado no curso.

- Não considero dificuldades do curso para atender os alunos do sistema de cotas, considero dificuldades de recursos, pouco professores de forma geral para atender a todos os alunos, considerando o aumento do número de vagas pelo REUNI.

- Não há dificuldades no acolhimento dos alunos do sistema de cotas.

Fonte: Dados da pesquisa.

Notamos que, na visão dos coordenadores, não existe dificuldade de acolhimento nos cursos. Só um coordenador de um dos cursos retratou que a dificuldade não está em atender aos estudantes oriundos das cotas, mas na falta de recursos e de professores. Com este fato fica evidente a necessidade da universidade em ampliar a quantidade de recursos oferecidos e 
aumentar o quadro funcional de professores, sendo esses os elementos fundamentais para uma educação de qualidade e inclusiva.

As universidades vêm ampliando o número de vagas e aderindo a políticas públicas de inserção e permanência, como fez por meio do Reuni, da lei 12.711 e do programa UFG/Inclui. No entanto, alguns requisitos importantes para essa implementação estão sendo deixados de lado como relatado pelos coordenadores, dificultando, assim, o acolhimento dos estudantes oriundo do sistema de cotas e inviabilizando a sua permanência no curso.

Em outra questão, buscamos saber como os cursos vêm tentando garantir a permanência dos estudantes oriundos do sistema de cotas e obtivemos resposta de todos eles. Nessa questão, eles poderiam selecionar mais de uma opção, era possível também escolher a opção "outros” e justificar.

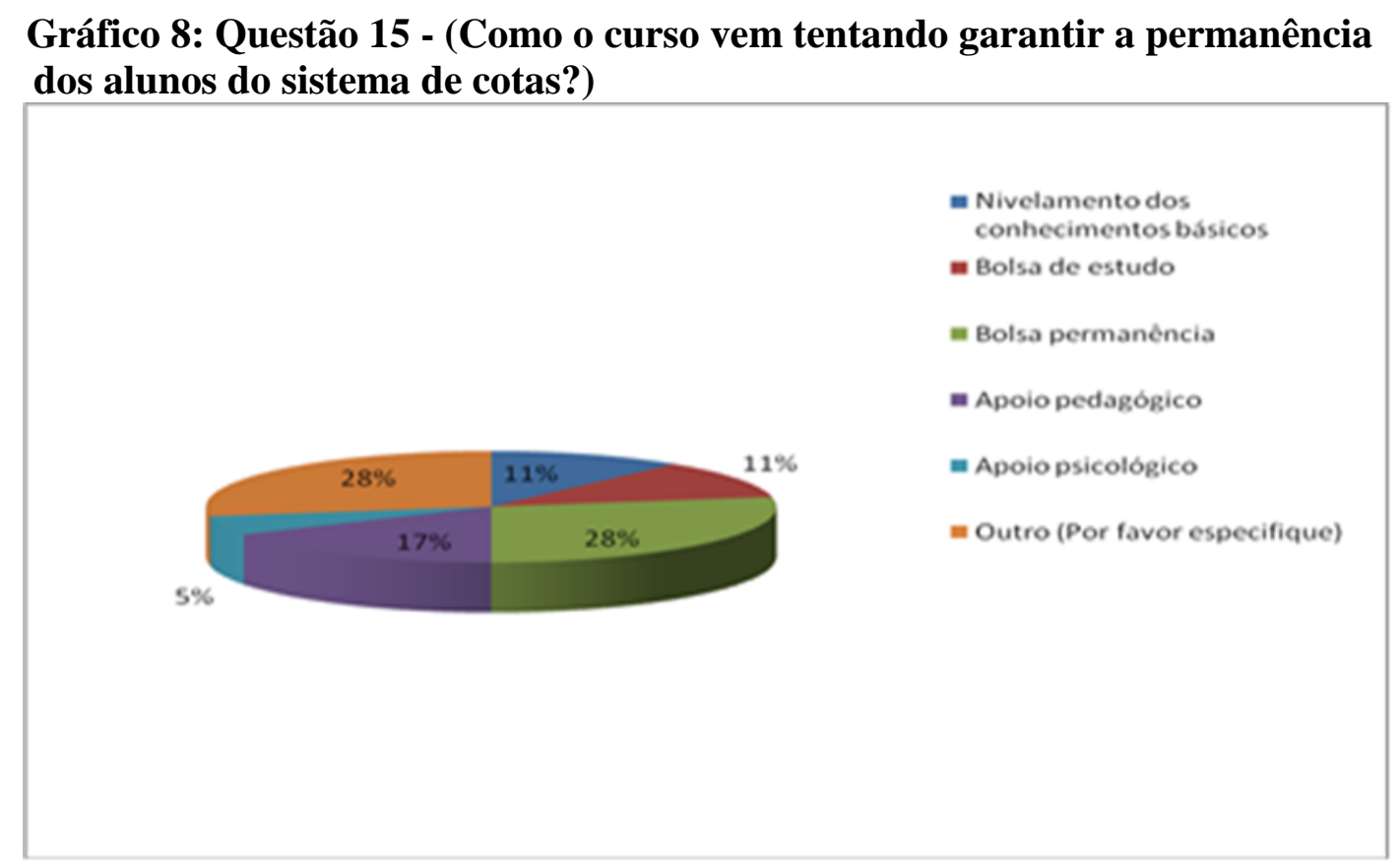

Fonte: Dados da pesquisa

As opções "outros" e "bolsa permanência" ficaram com 28\%; "apoio pedagógico", com 17\%; e "bolsa de estudo e nivelamento dos conhecimentos básicos", com 11\% e, por último, "apoio psicológico", com 5\%. Isso significa que a quantidade de bolsas disponíveis na UFG é pequena em relação ao número de alunos que possuem renda per capita familiar baixa, não atendendo a um terço dos estudantes.

Em relação à opção “outros”, os coordenadores afirmaram: 
Quadro 5: Questão 15 ( justificativa)

1. Essas medidas são tomadas para todos os alunos, do sistema de cotas e sistema universal. Todos entram com uma base matemática muito ruim. A UFG tem programa de bolsa permanência. No curso, tentamos fazer um nivelamento inicial, mas sem muita eficiência, para todos.

2. Ainda não identificado, os alunos têm bom desempenho no curso, as razões de permanência ou de desistência são semelhantes ao de não cotistas.

3. O curso não vem desenvolvendo ações neste sentido.

4. O mesmo apoio pedagógico que é dado aos demais alunos com dificuldades.

Fonte: Dados da pesquisa.

Como podemos observar somente alguns cursos promovem ações de permanência. No entanto, existem outras políticas de assistência desenvolvidas por meio do programa UFG/Inclui, as quais já foram apresentadas. A nossa compreensão é de que tais ações devem ir além das questões econômicas e financeiras, envolvendo práticas pedagógicas e psicológicas.

É consenso a ideia de que qualquer ação que favoreça o acesso de minorias na universidade deve ser acompanhada de mecanismos consistentes de apoio à permanência, considerando os aspectos econômicos, financeiros e também os referentes ao desempenho acadêmico mais especificamente. Isso reforça a preocupação apresentada na resolução do Consuni/UFG (2008, p. 20) de que: "não basta incluir, é preciso criar as condições de fato para que esses estudantes vivenciem a vida universitária em sua plenitude, assegurando a sua permanência até a conclusão do curso".

Perguntamos ainda aos coordenadores como os cursos se prepararam para atender aos estudantes oriundos do sistema de cotas a partir de 2013, considerando a lei 12.711/2012. Apenas dois dos nove coordenadores não responderam. 
Quadro 6: Questão 16 (Como os cursos estão se preparando para atender os alunos do sistema de cotas a partir de 2013, considerando a Lei 12.711?)

- Nenhuma medida nova.

- Estaremos mais atentos se soubermos quem são os cotistas.

- Consideramos que o aluno cotista não é diferente do nosso aluno de entrada pelo Sistema Universal. Isto porque a nota de corte é baixa e os alunos que entram pelo Universal também apresentam algumas dificuldades.

- Temos investido em monitoria mais próxima, inclusive lançando mão de alunos bolsistas REUNI do Mestrado.

- O curso de educação intercultural não tem cotas.

- Isso ainda não foi discutido na unidade.

- Em relação ao problema que temos identificado, baixo desempenho nas disciplinas (que não é específico dos cotistas!), o grupo tem discutido e pensado em termos de uma proposta dentro das disciplinas introdutórias do curso.

- O curso vem discutindo sempre algumas ações que promovam a permanência dos alunos no curso, independente se são ou não cotistas.

Fonte: Dados da pesquisa

As respostas apontam que os alunos do sistema de cotas e os do sistema universal são tratados da mesma forma nos cursos. No entanto, parece que o reconhecimento desses alunos não é uma preocupação presente. Poucos cursos estão preocupados em minimizar as dificuldades dos estudantes e discutir propostas para a realização de ações visando à permanência. Os dados levam a crer que a desistência dos alunos provenientes do sistema de cotas vem sendo discutida no âmbito universitário, mas de forma insuficiente. Já que foram poucos os coordenadores que relataram propostas de inserção e assistência estudantil a esses estudantes. Assim:

De modo geral, a ideia paradigmática do bem ensinar e aprender que se tornou hegemônica no âmbito de maior atuação da racionalidade docente, isto é, a sala de aula, apresenta diversos fatores, menos o reconhecimento do outro, ao ser pouco debatida nos sistemas de ensino a importância do lugar ocupado pelo aluno por princípio e igualdade de condição (TREVISAN, 2014, p 124).

Por último indagamos aos coordenadores como é a relação dos alunos do sistema de cotas e do sistema universal, ponderando alternativas: harmoniosa, preconceito, excludente e respeitosa. Nestas questões, dos nove coordenadores entrevistados, somente um não 
respondeu. Como podemos ver a relação dos alunos do sistema de cotas e do sistema universal, na visão dos coordenadores, é uma relação harmoniosa com sete, e respeitosa com um, não havendo, portanto formas de discriminação e exclusão, sendo respeitadas as diferenças dos sujeitos.

4.2. A percepção dos alunos que entram pelo sistema de cotas

Na primeira questão perguntamos aos alunos provenientes do sistema de cotas se eles conheciam as ações desenvolvidas no programa UFG/Inclui. Dos quinze que responderam, nove escolheram a opção sim e seis a opção não. Percebemos que alguns alunos conhecem o programa, outros não. Esse fator pode refletir de forma negativa na vida acadêmica dos estudantes que não tiveram acesso às informações sobre as ações de assistência desenvolvida na instituição, que possibilitariam concluir o curso de modo eficaz, já que as condições desfavoráveis (dificuldade financeira, baixo desempenho nas disciplinas, reprovações e outros) vivenciadas no curso podem provocar evasão como já expresso no capítulo 2.

Em outra questão, perguntamos se os alunos foram contemplados com alguma ação de assistência estudantil e quais foram. Um número optou pelo sim e destacou as seguintes: bolsa moradia, alimentação e permanência. Os alunos que responderam não haver divulgação do programa UFG/Inclui são os que não foram contemplados por nenhuma assistência estudantil, com exceção de um aluno que foi contemplado com a bolsa alimentação. Percebemos com as respostas que as ações de assistência estudantil não são garantidas a todos, indicando os limites do Programa como já visto nos capítulos anteriores.

Notamos ainda, que a falta de divulgação sobre o Programa se relaciona com o acesso à assistência. Nesse caso, se a UFG, como destacado pela Resolução Consuni/UFG (2008, p. 5, grifo nosso) tem "o compromisso com a democratização da educação, com a socialização dos seus benefícios, com o desenvolvimento cultural, artístico, científico, tecnológico e socioeconômico do país", precisa repensar os meios de divulgação e socialização do programa e também a ampliação e distribuição das ações de forma que o maior número de estudantes tenha acesso a elas.

Com o objetivo de identificar a efetividade do programa UFG/Inclui na vida acadêmica dos estudantes, perguntamos a eles, numa questão aberta, como o avaliam. Seguem as respostas no quadro abaixo: 


\section{Quadro 7: (Qual avaliação você faz do programa UFG/Inclui ? $^{23}$ )}

- Ótimo, pois pleiteia e oportuniza cidadãos que são colocados a mercê da sociedade a terem um "Q".

- Entendo que o programa é necessário, porém ainda necessita de algumas adequações.

- Acredito ser de fundamental importância.

- Ótima.

- É um programa excelente, pois ele proporciona oportunidade de inserção do negro, quilombola, indígena na Educação Superior.

- Seria nota 10 se houvesse vagas para todos.

- É uma oportunidade para alunos ingressarem em uma universidade federal, pois cadeiras vazias não faz país nenhum progredir. O aluno UFG/Inclui entra com dificuldade no primeiro semestre, porém depois conseguem acompanhar a turma.

- Boa.

- Muito bom.

- Razoável.

- Bom.

- Acredito ser um programa de inclusão social, que promove a Educação Superior.

Fonte: Dados da pesquisa

Podemos dizer que o programa é visto de forma positiva pelos alunos. Somente um estudante considerou esse programa razoável, mas não justificou. Analisando as respostas, é possível constatar que o programa não contempla a todos os estudantes e precisa de adequações que não foram citadas pelo respondente. Segundo a Resolução Consuni/UFG (2008 p. 5), a inclusão social necessita de uma "clara política de apoio ao estudante com vistas não somente ao seu acesso ao ensino superior, mas à sua permanência plena nos cursos de graduação das universidades públicas brasileiras até a conclusão dos mesmos”. Entretanto, podemos ressalvar, de acordo com os dados do capítulo 2 e com as respostas dos participantes

\footnotetext{
${ }^{23}$ As respostas dos sujeitos foram transcritas literalmente. As únicas intervenções que fizemos foram ortográficas.
} 
que, apesar de ser uma boa proposta e ter uma boa avaliação pelos alunos, o programa apresenta algumas dificuldade, como a falta de apoio pedagógico e a insuficiência de bolsas.

O gráfico 9 nos possibilita apreender se os estudantes estão sendo reconhecidos em suas singularidades e originalidades no âmbito universitário.

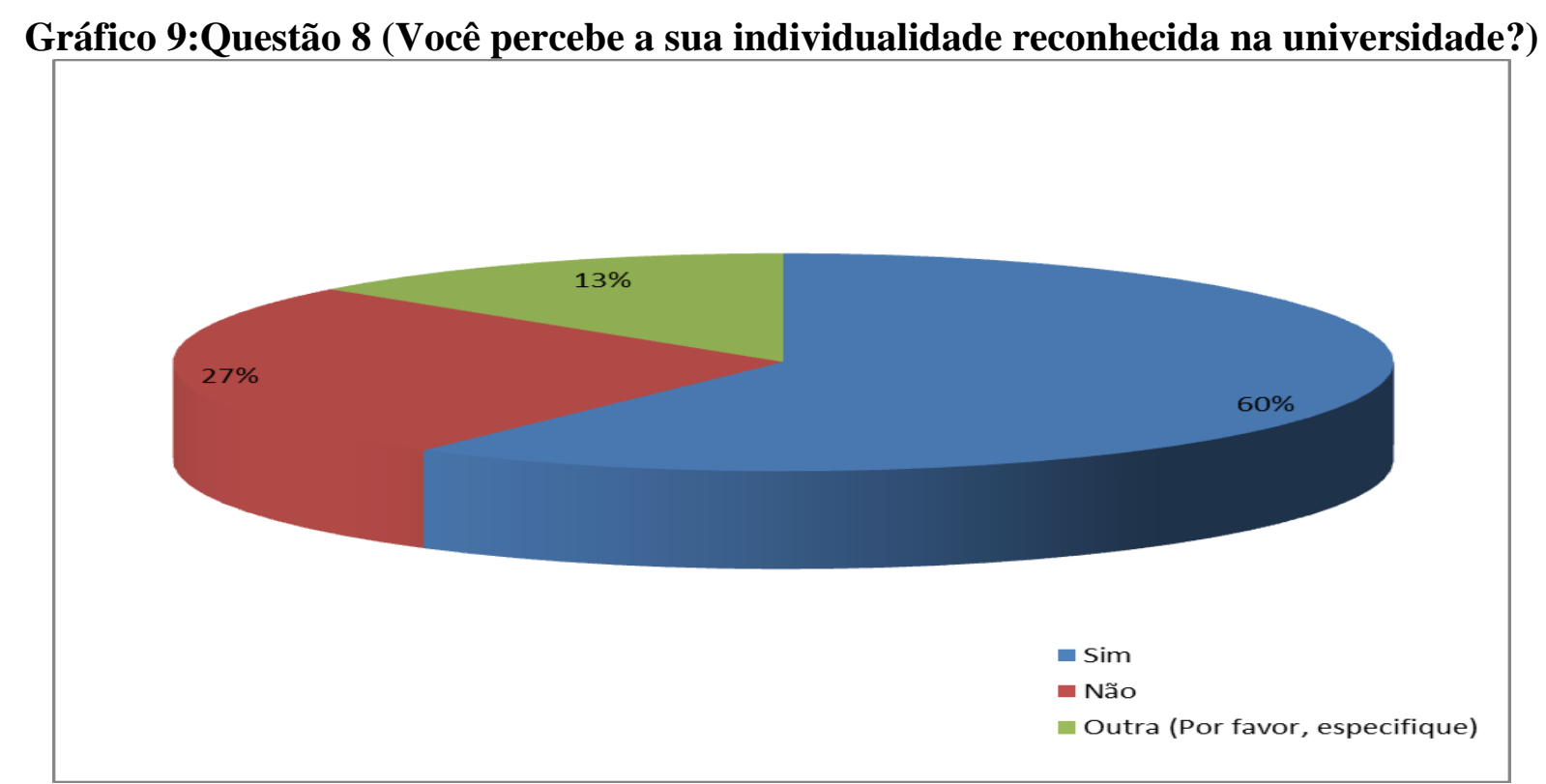

Fonte: Dados da pesquisa

A partir dos dados apresentados observa-se que $60 \%$ dos alunos percebem a sua individualidade reconhecida, $27 \%$ não percebem e treze optaram pela resposta "outra". Os participantes que escolheram a opção "outra” não justificaram a resposta. Esses dados nos mostram que a instituição está recebendo estudantes que, por muito tempo estiveram fora da Educação Superior, porém a questão do reconhecimento das singularidades é um tópico que ainda deve ser mais bem discutido e trabalhado. Esse fator nos faz questionar como o programa UFG/Inclui promove as ações de assistência, sem reconhecer as necessidades de todos os alunos. Como a universidade pode ser inclusiva, se não respeita a singularidade dos sujeitos que a integram? Para que haja inclusão é primordial considerar que todos os estudantes possuem as suas diferenças e essas devem ser ponderadas e respeitadas, para que estes se autorreconheçam como sujeitos aprendentes. Dessa forma é importante que as ações de assistência desenvolvida pela a UFG passem por "filtros de análise, levando em consideração o acolhimento às diferenças de gênero, etnia, cultura, sexo, cor, de deficiência etc” (TREVISAN, 2014, p. 18 e 19).

Segundo Honneth (2003), o não reconhecimento desencadeia o desrespeito, podendo este ameaçar a identidade do sujeito, não proporcionando a realização de sua moralidade e 
integridade, provocando consequências negativas à liberdade e a formação da identidade. Nesse sentido, o sujeito não consegue ver suas habilidades e capacidades como merecedoras de estima (autoestima), sendo esses fatores primordiais para a sua autorrealização na profissão.

Dando ênfase ainda à questão do reconhecimento das diferenças, perguntamos se o programa UFG/Inclui influencia no acolhimento das diferenças dentro da universidade. No total, onze alunos responderam a essa questão e somente cinco justificaram a sua resposta. No quadro abaixo, apresentamos apenas as respostas que foram justificadas.

\section{Quadro 8 : Questão 10 (Para você, o projeto UFG/Inclui influencia no acolhimento} das diferenças dentro da universidade?)

- Sim, pois de algum modo ele permite que alunos independente da cor, etnia ou nível econômico tenham a possibilidade de ingressar em cursos os quais comumente participam apenas uma elite econômica.

- Sim, de forma positiva.

- Sim, pois há um respeito muito grande por parte de todos.

- Não, porque não se sabe quem entrou pelo UFG/Inclui. No entanto, é possível escutar comentários de alunos contra tal programa.

- Não, dentro da universidade o que vale é ser um bom profissional, não importa as diferenças. O papel da universidade é oferecer estrutura e bons professores, como mediadores da educação.

Fonte: Dados da pesquisa

De acordo com a resolução Consuni/UFG (2008, p. 8), o programa UFG/Inclui reconhece a existência das "diferenças individuais, socioeconômicas e culturais que influenciam no modo pelo qual os sujeitos adquirem e constroem os conhecimentos e as habilidades que compõem a sua formação.” Mas pelas respostas apresentadas no questionário, notamos que, para alguns estudantes, o programa UFG/Inclui não influencia no acolhimento das diferenças, já outros alunos acreditam que sim. Desse modo, é possível observamos uma limitação das ações, pois não alcançam a totalidade dos alunos do sistema de cotas, apresentando lacunas em relação ao reconhecimento da originalidade e particularidade desses, impossibilitando assim o desenvolvimento de ações condizentes com sua realidade.

Considerando que as ações de assistência é uma maneira de proporcionar o desenvolvimento acadêmico dos estudantes, procuramos analisar como tais ações acontecem 
na universidade. Sendo assim, na questão onze perguntamos aos alunos se eles achavam que as ações desenvolvidas na UFG garantiam o desenvolvimento acadêmico. Dos treze que responderam somente um disse que não. Diante disso, podemos dizer que o programa vem alcançando um dos seus objetivos propostos na resolução Consuni/UFG (2008, p. 12), que visa a "acompanhar a trajetória dos estudantes que ingressarem por meio do UFG/Inclui, com vistas a fornecer apoio institucional para o seu bom desempenho acadêmico". Na questão doze, pedimos aos alunos que justificassem a resposta escolhida na questão 11 . 


\section{Quadro 9: Questão 11 (justifique a resposta da pergunta 11)}

- Apesar de perceber que a assistência não alcance todos os alunos que necessitem desta, ela ajuda muitos alunos a poderem focar melhor nos estudos do que em horas de trabalhos os quais podem distanciá-los da rotina diária da faculdade.

- Sim, pois o aluno não tem que dividir seu tempo com outras atividades para manter-se na universidade. Pode dedicar-se exclusivamente aos estudos e assim ter um melhor desenvolvimento acadêmico.

- Acredito que ainda há formas de melhorar, mas a Universidade está no caminho certo.

- Sim, pois as mesmas oportunizam um desenvolvimento de qualidade.

- Sim, pois quando você está em um projeto você está dedicando ao aprendizado, mas o que se paga é pouco e não dá para se suprir as necessidades básicas de uma pessoa muito menos de uma família. Mas é muito validado para o aprendizado, pois vi colegas dar um salto enorme em sua vida acadêmica.

- O ingresso garantido é a base para o desenvolvimento.

- Pois garante o dia-a-dia do aluno, e sacia as necessidades básicas, mesmo que não supra completamente todas as dificuldades, é o suficiente.

- Sem as políticas de assistência, seria impossível aos alunos permanecerem nos cursos.

- Sim, no meu caso precisava trabalhar pra conseguir me manter na universidade e com a Bolsa Permanência consegui continuar um bom tempo estudando e trabalhando dentro da própria universidade.

- Pois é uma ajuda para que ele possa estudar.

- Sim. O papel da universidade é ajudar.

- Não garante, pois o aluno tem que fazer sua parte também, muitos ganham assistência e não aproveitam para se desenvolver no âmbito acadêmico. Acredito que há a necessidade das ações e o aluno se dedicar e aproveitar a oportunidade.

Fonte: Dados da pesquisa

As respostas revelaram que as ações não contemplam a todos os alunos. Apesar disso, uma parcela significativa dos estudantes percebe as ações como uma ferramenta de acesso e de ajuda, permitindo-lhes maior dedicação aos cursos. Ao não terem que dividir seu tempo com outras atividades/trabalho, obtêm um melhor resultado nos estudos. Havendo, assim, 
uma diminuição das reprovações e desistências. É importante considerar ainda que nem todos os alunos acreditam que as ações de assistência garantem o desenvolvimento acadêmico, pois alguns são contemplados com as ações, mas não se dedicam ao curso.

A necessidade de trabalhar enquanto realiza o curso é uma das condições de muitos estudantes do sistema de cotas, como pudemos observar na tabela 3 do capítulo 2, pois, em quase todos os anos, a forma escolhida pelos alunos de se manterem na universidade foi trabalhando com recursos próprios. Ou seja, um fator que deve ser ponderado pela instituição de Educação Superior. Visto que, quando o indivíduo é desprovido de seus direitos, ele perde a sua capacidade de se idealizar como parceiro de interação com as mesmas condições igualitárias dos outros, vendo-se como inferior na coletividade da universidade.

Conforme já abordamos nos capítulos anteriores, a UFG por meio do programa UFG/Inclui desenvolve ações de assistência estudantis antes, durante e depois da entrada do aluno na universidade, com a finalidade de promover o acesso e a permanência. Diante disso, buscamos apreender quais outras ações os estudantes acham necessárias que a intuição ofereça.

Quadro 10: Questão 12 (Do seu ponto de vista, que ações de assistência estudantil a universidade deve oferecer para que todos os alunos sejam reconhecidos?)

- 1.Melhor divulgação das assistências já existentes; 2. Redução da burocracia; 3. Algum tipo de auxílio que alcance pessoas que também precisam trabalhar; 4. Abertura de concursos internos voltados apenas para o público estudantil e não o público em geral; 5. Cobrar dos órgãos competentes que viabilizem algum tipo de transporte coletivo que atenda especialmente (senão exclusivamente) o público estudantil da metrópole e região.

- Bolsas de iniciação científica voltadas para alunos do programa UFG/inclui, visto que o atual número de bolsas destinadas a esse público ainda é muito inferior aos destinados aos alunos que ingressam no método universal. É muito mais fácil e viável ao aluno do UFG/Inclui concorrer às vagas de bolsa Pibic universais do que às destinadas ao programa, suas chances de conseguir a bolsa é muito maior.

- Mais incentivo às pesquisas, fornecendo mais bolsas para esses fins, e também alguma forma de incentivar os estudantes a escolherem e permanecerem nos cursos de licenciatura.

- Mais debate, reuniões envolvendo a participação de todos os acadêmicos. 
- Sim, pois todos temos necessidades, mas a maior necessidade é principalmente de aprendizado. Deveria fazer uma entrevista e saber o que aluno quer e se preenche os requisitos e se tem compromisso ou só necessidades.

- Alunos que foram contemplados com bolsa durante o Ensino Médio, mas que passam por dificuldades assim como todos os outros.

- As mesmas que já oferece.

- Bons estágios, bons professores, campus de qualidade.

Fonte: Dados da pesquisa

As informações permitem inferir que as ações mais solicitadas pelos estudantes se referem ao ensino e à pesquisa. Alguns dão destaque a ações financeiras e transporte. Nessa questão os estudantes também ressaltam a necessidade de uma melhor divulgação e menor burocracia das ações promovidas pela instituição; professores mais qualificados; aumento do número de bolsas de iniciação científica e debates e reuniões envolvendo a participação de todos os acadêmicos. Como o Centro de Seleção também buscou apreender quais serviços complementares os estudantes preferem que a universidade realize para atender a suas necessidades. Dentre as opções apresentadas, a mais escolhida foi bolsa trabalho e bolsa alimentação.

Desse modo, as ações oferecidas pela UFG só proporcionarão o reconhecimento quando as individualidades dos alunos forem aceitas e respeitadas, suprindo as suas necessidades de acordo com as suas demandas. Para isso, é preciso dar voz aos mesmos, de forma que possam expressar as suas dificuldades/necessidades vivenciadas no percurso do curso, tanto no que se refere à questão da aprendizagem quanto à financeira.

As respostas às questões 14 e 15 do questionário dos estudantes retratam o relacionamento dos alunos do sistema de cotas com os alunos do sistema universal e com os professores, considerando quatro alternativas: harmoniosa, preconceito, excludente e respeitosa. No que se refere ao relacionamento entre os colegas, oito estudantes optaram por harmoniosa e seis respeitosa. Já em relação aos professores, cinco alunos escolheram a opção harmoniosa e nove, respeitosa. Essa questão nos permite verificar que, na visão dos alunos, não há preconceitos e nem exclusão dentro dos cursos, sendo as diferenças respeitadas e valorizadas. Acreditamos que, a partir do momento em que as diferenças são reconhecidas pelos outros membros da sociedade, o indivíduo consegue perceber suas capacidades e realizações como valiosas para a sociedade. Ou seja: "só na medida em que eu cuido 
ativamente de que suas propriedades, estranhas a mim, possam se desdobrar, os objetivos que nos são comuns passam a ser realizáveis" (HONNETH, 2003 p. 211).

Visto que as relações são harmoniosas e respeitosas entre os alunos e professores, a pergunta seguinte teve como intuito verificar se alguma vez os estudantes do sistema de cotas foram discriminados dentro da instituição. Com o gráfico, evidenciamos que das treze respostas dez (77\%) escolheram a opção "não" e três (23\%) optaram pelo "sim”.

\section{Gráfico 10: Questão 16 (Alguma vez você foi discriminado por ser aluno oriundo do sistema de cotas?)}

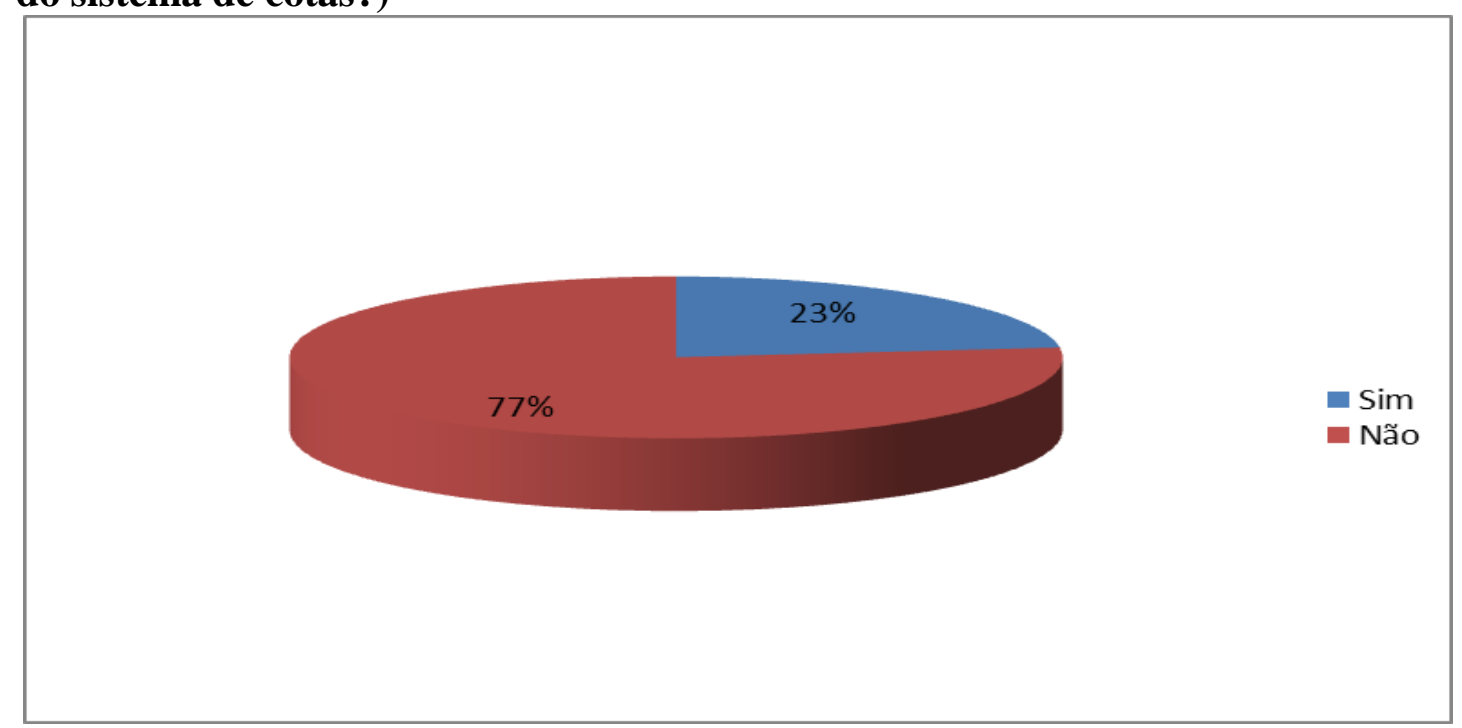

Fonte: Dados da pesquisa

Dos treze participantes que responderam à questão dezoito, somente oito justificaram a resposta, frisando que a discriminação ocorre de forma velada, pois não são divulgados os estudantes oriundos do sistema de cotas. Um respondente destacou:

Não diretamente. Visto que alunos do Sistema Universal não sabem se você é aluno proveniente das cotas ou não a menos que reconheça. Normalmente, taxam que estes alunos seriam os de menor rendimento, o que nem sempre é verdade. Comentário contra o UFG/Inclui eram mais comuns no ano de 2010, meu ano de entrada. Hoje essa discussão já está saturada. (A1)

Infelizmente a discriminação está presente em nossa sociedade, às vezes de forma explicita ou velada como foi relatado pelos estudantes do sistema de cotas. Bem sabemos que essa realidade atravessa gerações, não sendo algo da atualidade. É primordial entendermos "que a redenção das diferenças e da pluralidade se encontra no nível da implicação mútua, isto é, na atitude de reconhecimento (de um plano cultural pelo outro), que serve de base para 
gerar conhecimento (menos preconceituosos e mais produtivos sobre o assunto)" (TREVISAN, 2014, p. 166).

Nota-se que há alguns anos essa temática vem sendo discutida com o objetivo de suprimir tal prática, exemplo disso, foi a constituição de 1988 que veda qualquer tipo de discriminação entre as pessoas e a Conferência de Durban (2001), que responsabilizou os Estados para pôr fim à discriminação e ao racismo, reparando os danos do passado, tendo o compromisso de corrigir a desigualdade social por meio das políticas públicas. Desde então, o Brasil vem criando políticas de ações afirmativas que proporcionem a inserção dos grupos excluídos e discriminados, que por muito tempo não tiveram os seus direitos fundamentais reconhecidos e respeitados. Contudo, constata-se que as práticas discriminatórias ainda estão impregnadas em nosso meio.

Dessa maneira, Silvério (2005) frisa que a Educação Superior, que trabalha com o ingresso diferenciado e que tem como finalidade a justiça social e racial, deve buscar retificar e eliminar as formas de discriminação vivenciada, muitas vezes, por esses grupos. Entende que esse tipo de ação não significa esmola ou favorecimento indevido, pois os estudantes que entram por meio de ações afirmativas comprovaram possuir o mínimo de competências para entrar na universidade. Logo, faz-se necessário que as instituições de ensino forneçam uma bagagem sólida de conhecimentos, apoio pedagógico, material e afetivo para que o aluno obtenha o sucesso acadêmico. É primordial também a articulação entre a teoria e a prática e o oferecimento de uma atitude científica, ética, política, didática e técnica, integrando: um saber científico embasado em estatuto epistemológico e no método correspondente ao conhecimento que será trabalhado; um saber pedagógico que proponha uma reflexão de toda a prática educativa; um saber cultural e político que possibilite ao educador compreender a relação entre a educação, a cultura e a sociedade; um saber transversal que proporcione a multidisciplinaridade, a interdisciplinaridade e a transdisciplinaridade relativamente ao conhecimento, às informações e à metodologia (BRZEZINSKI, 2008).

Questionou-se ainda, os estudantes sobre a dificuldade de se reconhecerem como alunos provenientes do sistema de cotas. Todos os respondentes disseram que não. Nesta questão, os participantes tiveram a possibilidade de comentar a resposta, caso julgassem necessário. Foram totalizados onze comentários. 
Quadro 11: Questão 15 (Você tem dificuldade de se reconhecer como aluno proveniente do sistema de cotas? Justifique.)

$\checkmark$ Não, da ocasião se fez a oportunidade, isto é, fico feliz pela oportunidade
pleiteada e galguei da melhor forma possível a minha formação, e de maneira alguma esqueci
as minhas raízes, e por isso não tenho dificuldade de me reconhecer como estudante
proveniente das cotas.
$\checkmark$ Na verdade tentei entrar pelo sistema de cotas, porém depois descobri que
teria sido melhor, em meu caso, ter tentado pelo sistema universal, porém, independente
disso, não vejo problema algum em tentar o ingresso por meio de cotas.
$\checkmark$ Se não fosse o sistema de cotas não estaria na universidade.
$\checkmark$ Tenho orgulho de ser aluno do sistema de cotas, saber que venho de uma
escola pública e apesar das dificuldades.
$\checkmark$ Não, pois me sinto igual a todos.
$\checkmark$ Não. Pois sou negra tenho dificuldade de escrever e ler. Como posso negar
$\checkmark$ Nenhuma, pois cadeiras vazias não fazem Universidade, é preciso ocupar
tudo.
aquelas cadeiras. Agora, o aluno que conseguir passar tem que ser por mérito.
$\checkmark$ Não. Tenho consciência da minha realidade social. Eu busquei a Universidade
justamente para superá-las, e conseguir um futuro melhor.
$\checkmark$ Não sou aluno proveniente de cotas. Embora tenha solicitado a participação,
posteriormente ao meu ingresso, soube que eu não havia entrado como cotista.
$\checkmark$ Não há motivos para não se reconhecer como aluno do sistema de cotas, as
oportunidades são para todos e que importa é ser um bom profissional.
$\checkmark$ Não tenho dificuldade, pois ser aluno proveniente do sistema de cotas não me
torna diferente de um aluno que não é. Na sala de aula e na universidade somos um só,
independente do sistema que entramos.

Fonte: Dados da pesquisa

Observamos que os alunos não negam a sua entrada pelo sistema de cotas, pelo contrário, sentem-se satisfeitos pela oportunidade de terem acesso a universidade por meio dessa ação, reconhecendo-se como sujeitos de direitos iguais, independente das suas diferenças e particularidades. Afirmam que, apesar das dificuldades encontradas no decorrer do curso, podem ter um bom desempenho nas disciplinas e podem se tornar profissionais de qualidade.

De acordo com Honneth (2003), devemos lembrar que o reconhecimento se dá em um processo recíproco, pois, sem a interação, os sujeitos não podem reconhecer suas ações como algo pertencente a ele. A partir do momento em que o aluno é reconhecido pelo outro, sentese como indivíduo de igual valor na sociedade. Sendo as suas habilidades reconhecidas, atribui, assim, valores às suas capacidades, e se reconhece como sujeito de igual valor, independente de ser indígena, negro ou proveniente de escola pública. 
A questão 20, apresentada no gráfico11 trata da realização do estudante do sistema de cotas dentro do curso.

\section{Gráfico 11: Questão 17 (Você se sente realizado no curso?)}

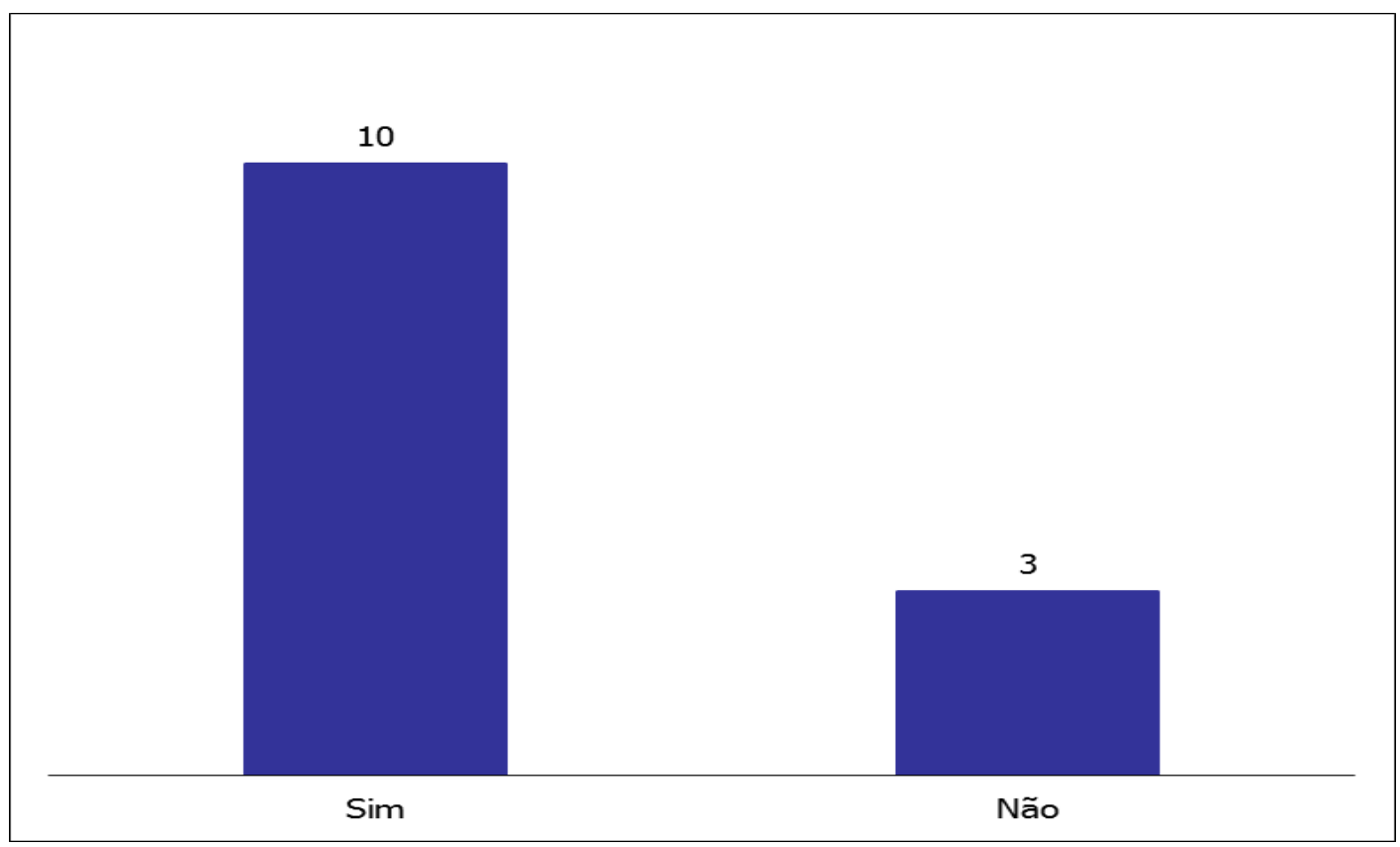

Fonte: Dados da pesquisa

Nem todos responderam a essa pergunta, somente treze alunos. Um total de dez participantes se sentem realizados no curso, apenas três não se sentem realizados. Isso significa que a maioria dos estudantes que responderam a essa pergunta se sentem realizados no curso. Dessa forma os alunos estarão mais motivados a estudarem e permanecerem na instituição, tendo assim um bom desempenho acadêmico. Acreditamos que, quando as singularidades e capacidades dos estudantes forem reconhecidas pelo outro, ele se autorrealizará de forma positiva e permanecerá na instituição, obtendo êxito, e se tornando um profissional satisfeito.

Questionamos também os alunos sobre as dificuldades encontradas no decorrer do curso. 


\section{Quadro 12: Questão 19 (Quais as dificuldades encontradas em seu processo de formação} dentro da UFG?

- No meu caso a maior parte dos problemas diz respeito a doenças e transporte.

- Bom, no início tive dificuldades com algumas leituras mais complexas.

- A UFG facilita bastante o processo de formação, não vejo nenhuma dificuldade a relatar.

- No início tive bastante dificuldade, principalmente em relação à adaptação, mas aos poucos fui me adaptando, outra dificuldade encontrada era em relação ao conhecimento, às vezes me sentia um pouco excluída em relação à participação, pois sempre tive dificuldade na linguagem, por ter um sotaque meio diferente e isso fazia com que eu me sentisse incapaz, mas com o passar dos anos percebi que estava ali juntamente com todos para aprender, ou seja, com um mesmo objetivo que era adquirir o "aprendizado".

- Me falta tempo para estudar da maneira adequada. Gostaria que tivesse um professor para tirar dúvidas que me ajudassem na melhor maneira de estudar.

- Como tranquei, fica difícil de voltar e pegar as matérias.

- Sempre financeira, o que nunca me levou a querer parar o curso, pois minha força de vontade é maior. No entanto, atrasei o curso, visto que para um trabalhador, conseguir horário flexível no curso que diz ser noturno é difícil, e essa é outra dificuldade.

- O meu curso é integral e os horários são desorganizados, de modo que só quem vive exclusivamente para estudar consegue cumprir o programa.

- Conciliar horários de trabalho com o estudo.

- Nenhuma.

Fonte: Dados da pesquisa

A questão 22 nos possibilitou compreender que as dificuldades dos estudantes estão configuradas na conciliação trabalho e estudo; dificuldades na aprendizagem; condições financeiras; transporte e doença. Isso pode ser reflexo da inativação dos alunos como foi abordado na tabela 6. Frente a essa realidade, entendemos que cabe a UFG ampliar as suas políticas de assistência, proporcionando mais atividades de tutoria, acompanhamento pedagógico, oportunidade de participar do programa UFG/inclui, além de ampliar o número de bolsas de alimentação, moradia e permanência. 
Frisando ainda a questão da formação, perguntamos aos participantes quais ações a UFG deveria oferecer para que tivessem um bom desenvolvimento no curso. Nem todos responderam à pergunta. Entre os comentários podemos destacar a questão da didática dos professores; a flexibilidade quanto à realidade social do aluno; a organização curricular, principalmente no que diz respeito às políticas públicas e a necessidade de uma melhor articulação entre a teoria e a prática. Diante desse fato a universidade juntamente com os professores deve repensar as políticas de inclusão e as ações pedagógicas, considerando a realidade dos educandos, para que esses obtenham sucesso acadêmico.

Desse modo, entendemos que a formação inicial deva garantir ao futuro professor o seu desenvolvimento profissional buscando sempre articular a teoria com a prática e, além disso, proporcionar o exercício da sua autonomia. Segundo Imbernón (2011, p. 63), “a estrutura da formação inicial deve possibilitar uma análise global das situações educativas que devido à carência ou à insuficiência da prática real, se limitam predominantemente a simulações dessas situações".

Portanto, à universidade cumpre formar professores que estejam preparados para encarar as vicissitudes e as barreiras presentes nas situações reais no âmbito escolar e refletir sobre as mesmas com o objetivo de construir a sua autonomia profissional. Para isso, é necessário um currículo adequado à realidade da instituição e professores que estejam comprometidos em formar sujeitos realizados, desenvolvendo práticas que não sejam meramente um exercício mecânico e técnico.

$\mathrm{Na}$ última questão, perguntamos o que os estudantes pretendiam fazer em relação às políticas de inclusão quando estiverem na escola. Obtivemos doze respostas:

Quadro 13: Questão 21 (O que você pretende fazer em relação às políticas de inclusão quando estiver na escola?)

- Lutar para reconhecer os valores de cada um.

- Ajudar a divulgar estas políticas e se conseguir até mesmo desenvolver algumas outras.

- Nunca pensei nada a esse respeito, a não ser motivar meus alunos a continuarem seus estudos, no sentido de contribuir para formação pessoal de cada um deles, pois querendo ou não a universidade é um espaço de reflexão e mudança.

- O primeiro recurso é a fala, conversar com os alunos e ouvi-los também, é muito importante. 
- Conscientizar o educando sobre as diferenças respeitando-as para que seja proporcionada uma educação de qualidade a todos.

- Mostrar para os alunos que são capazes e mostrar as informações de como correr atrás de suas vagas.

- Tratar todos iguais, só passam aqueles que têm mérito.

- Muito difícil. Pessoalmente quero colocar esses assuntos em destaque, e discuti-los para encontrar soluções. No entanto, é necessário um esforço coletivo para que funcione.

- Não pretendo estar na escola básica.

- Fazer com que ela seja feita de verdade.

- Mostrar exemplo.

- Não há uma ação específica, acredito que temos que levar a inclusão com naturalidade, se ficarmos pensando em ações para isso, nunca conseguiremos atingir a inclusão, acho que ela já está aí, então cabe a nós continuarmos normalmente.

Fonte: Dados da pesquisa

Com os comentários, percebemos que os estudantes pretendem divulgar mais as políticas de inclusão já implementadas; garantir a efetivação das mesmas; e se, possível, criar outras de acordo com as necessidades dos seus alunos, e, ainda, promover discussões sobre o assunto com o intuito de favorecer soluções. Esses dados nos revela que os alunos buscam garantir o acesso a educação a todos os cidadãos que por muito tempo estiveram fora deste sistema, e, além disso, visam desenvolver debates e ações voltada para uma educação inclusiva.

É importante destacar que um dos estudantes relatou não haver necessidade de ficar implementando políticas de inclusão, pois ele acredita que pensar ações para tal realidade não é um processo que garanta a inclusão, devendo tal assunto ser tratado com naturalidade. Bem sabemos que, sem as políticas de inclusão, uma parcela expressiva da população estaria fora das salas de aula, não teria oportunidade de estudar ou ter auxílios que os ajudasse a permanecer no ambiente escolar. Essas políticas têm o papel de garantir a todos o direito de se inserirem em um ambiente educacional, e de tornar as universidades um espaço mais inclusivo, valorizando as diferenças sociais, culturais e físicas, onde todos sejam tratados com igualdade e respeito. Concordando com Honneth, entendemos que é através do direito que o indivíduo se reconhece reciprocamente como pessoa de igualdade, uma vez que esse tem 
como base os princípios morais e a igualdade estabelecida pela lei, beneficiando não somente uma parcela da população, mas todas as pessoas. "Visto que possuir direitos individuais significa poder colocar pretensões aceitas, eles dotam o sujeito individual com a possibilidade de uma atividade legítima, com base na qual ele pode constar que goza do respeito de todos os demais" (HONNETH, 2003, p. 197).

4.3. A importância do reconhecimento do outro na formação do profissional docente

Os dois questionários nos permitiram compreender a visão dos coordenadores e dos estudantes em relação à influência do reconhecimento na formação dos professores. Diante de tais dados, compreendemos que a UFG vem garantindo o acesso dos estudantes e promovendo políticas de assistência por meio do programa UFG/Inclui, que tem como objetivo minimizar a exclusão de grupos excluídos da Educação Superior, criando medidas que proporcionem o ingresso e a permanência desses. Mas, de acordo com os dados encontrados, o programa possui algumas lacunas que poderiam ser reparadas.

Como afirmamos, a inserção não garante aos alunos do sistema de cotas o sucesso e a conclusão do curso. É importante que as suas potencialidades e capacidades sejam reconhecidas, assim eles desenvolverão a sua autonomia e construirão a sua identidade em um processo coletivo, sendo respeitadas e valorizadas as suas diferenças. Pois o reconhecimento poderá proporcionar o autorrespeito, a autoestima e a autoconfiança, sendo estas as três formas de o indivíduo se relacionar consigo mesmo e com o próximo, caracterizando essas esferas como essenciais para que os futuros professores tenham um bom desempenho acadêmico e profissional. Uma vez que: "sem a experiência de um parceiro de interação que lhe reagisse, um indivíduo não estaria em condições de influir sobre si mesmo com base em manifestações autoperceptíveis, de modo que aprendesse a entender aí suas reações como produções da própria pessoa" (HONNETH, 2003, p. 131).

Acreditamos que a UFG poderá se tornar uma instituição mais inclusiva se as suas ações perpassarem pelas esferas do direito, da igualdade e da democracia, garantindo aos estudantes a formação da sua identidade profissional, sendo esta formada individualmente e coletivamente. Para Honneth (2003, p. 129 e 130), a identidade coletiva e individual dos sujeitos é formada por meio do reconhecimento social intersubjetivo. Estando a autoconsciência humana ligada à "capacidade de suscitar em si o significado que a própria ação tem para o outro, abre-se para o sujeito, ao mesmo tempo, a possibilidade de considerarse a si mesmo como um objeto social das ações de seu parceiro de interação". 
Dessa maneira, a instituição poderia promover praticas pedagógicas inclusivas para os estudantes provenientes do sistema de cotas, atendendo as suas características e necessidades, evitando desse modo a exclusão consequente da discriminação frente ao outro. É preciso cuidar da formação inicial, pois, como defende Imbernóm (2010), É nessa etapa que os conhecimentos básicos e necessários para atuação profissional são apreendidos, possibilitando aos futuros educadores o enfrentamento das dificuldades e as barreiras encontradas no cotidiano da escola.

A pesquisa nos permitiu verificar que a questão do reconhecimento vem sendo tratada de modo superficial, tendo em vista que as particularidades e singularidades dos estudantes são pouco consideradas. Esse fato pode repercutir de forma negativa na vida profissional dos educandos, podendo levá-los a desenvolverem práticas pedagógicas distantes da realidade de seus alunos, não considerando estes em suas singularidades. Lembrando que o reconhecimento:

(...) não é uma simples fórmula, mas sim algo muito exigente, uma vez que só funciona, ao nível da compreensão, na base da busca e aceitação da diferença. Logo, o efeito educativo no comportamento de um indivíduo depende de um agir racional, porém, conjugado à influência do meio natural. Posso arriscar nesse sentido a dizer que, sem levar em consideração a articulação de ambos os elementos, nenhuma iniciativa pedagógica produzirá o efeito desejado em sua intencionalidade (TREVISAN, 2014, P. 145).

Sendo assim, defendemos que a UFG precisa garantir melhor ao estudante o seu reconhecimento, pois a violação do mesmo traz prejuízos para o desenvolvimento da autonomia e da identidade dos sujeitos que serão profissionais da educação. Isso porque a “integridade do ser humano se deve de maneira subterrânea a padrões de reconhecimento [...], pois, na autodescrição dos que se veem maltratados por outros, desempenham até hoje um papel dominante categorias morais que, como as de "ofensas" ou de "rebaixamento" (HONNETH, 2003, p. 213), se referem a formas de desrespeito, ou seja, as formas do reconhecimento recusado. "Nesse caso o indivíduo permite que seus atos percam a capacidade de implicar-se positivamente com o outro e, portanto, governados por atitude de negação do reconhecimento original" (TREVISAN, 2014, p. 19).

Além disso, entendemos a relevância de se trabalhar com a realidade dos estudantes, considerando seus conhecimentos prévios, experiências e opiniões, pois estes são oriundos de vários contextos culturais e caracterizam diversos segmentos sociais, não sendo iguais e nem homogêneos. Uma vez que as ações pedagógicas, não atendendo às suas necessidades, podem 
provocar um baixo desenvolvimento acadêmico ou até mesmo o abandono do curso, ou impedindo esse estudante de se autorrealizar como profissional.

Portanto, quando os licenciados não reconhecidos, eles poderão não identificar seus projetos como algo importante para a sociedade ou para as escolas na qual atuarão ou já atuam como professores, apresentando dificuldades de construírem a sua identidade profissional, sentindo-se inseguros na realização da sua prática. Assim, entendemos que a formação deveria possibilitar ao professor pensar sobre suas ações no âmbito escolar e proporcionar atitudes de confiança e responsabilidade para exercer um bom trabalho. Sendo primordial também o oferecimento de uma atitude científica, ética, política, didática e técnica, visando a alguns fatores fundamentais como: um saber científico embasados em estatuto epistemológico e no método correspondente ao conhecimento do qual irá trabalhar; um saber pedagógico que propõe uma reflexão de toda a prática educativa; um saber cultural e político que dá a possibilidade do educador compreender a relação entre a educação, a cultura e a sociedade; um saber transversal que proporcione a multidisciplinaridade, a interdisciplinaridade e a transdisciplinaridade no que abrange o conhecimento, as informações e a metodologia (BRZEZINSKI, 2008).

Nesse sentido, reafirmamos o quanto é primordial o reconhecimento do outro para que os futuros professores possam exercer sua autonomia e se reconhecer em suas práticas, tornando-se profissionais "dotados de competência para produzir conhecimentos sobre o seu trabalho, de tomar decisões em favor da qualidade cognitiva das aprendizagens escolares e, fundamentalmente, de atuar no processo constitutivo de cidadania do aprendente" (BRZENZISKI, 2008, p. 15). Pois é por meio das relações individuais e coletivas que os educadores vão construindo a sua identidade e satisfação profissional, tornando-se professores críticos e reflexivos, autores de suas próprias ações. 


\section{CONSIDERAÇÕES FINAIS}

Este trabalho discutiu a questão do reconhecimento dos alunos do sistema de cotas dos cursos de licenciatura presenciais da UFG regional Goiânia. A instituição vem promovendo várias ações afirmativas com o objetivo de inserir uma parcela significativa de estudantes que por muitos anos não tiveram acesso ao ensino superior. Dentre as ações desenvolvidas podemos destacar a adesão ao PET, a vinculação com o Programa de Bolsas de Licenciaturas, a implementação do projeto "Passagem do meio", efetivação do Programa Bolsa Permanência, expansão com o Reuni, entre outras.

Além dessas ações desde 2008, por meio do programa UFG/Inclui, a universidade implementou o sistema de cotas e ações de permanência. Esse programa partiu de uma política de inclusão e permanência de alunos nos cursos de graduação, tendo como objetivo propor ações antes, durante e depois do processo seletivo, acompanhando todo o processo do aluno e objetivando promover a igualdade e o combate à discriminação. Entre as ações planejadas, podemos destacar: os cursos de graduação para inclusão de grupos sociais específicos; programa institucional de iniciação científica; programa de bolsa alimentação, monitoria, permanência; creche; moradia estudantil; programa saudavelmente; restaurante universitário e programa de concessão de passagens para alunos da graduação.

Em 2012, com a criação da Lei 12.711, ocorreram algumas mudanças no regulamento do programa UFG/Inclui. O programa incluiu e passou a ter como público alvo os alunos quilombolas, indígenas e surdos. Já os alunos de escola pública e negros de escola pública continuaram amparados pela Lei 12.711. No ano de 2010 a Faculdade de Letras, solicitou à reitoria através da Resolução Consuni/UFG no 20 a implementação o curso de Letras Libras no programa UFG/Inclui, com o objetivo de expandir o número de estudantes surdos no curso. Faz-se necessário ressaltar que a instituição no ano de 2015 aderiu integralmente ao Sisu, o qual se utiliza das notas do Enem como critério para a classificação de novos alunos.

As ações afirmativas no âmbito da Educação Superior são o resultado de vários debates e conflitos no campo das políticas educacionais e que têm como finalidade dar acesso aos egressos de escola pública, negros, pardos, indígenas, quilombolas e deficientes e baixa renda, os quais, por muitos anos, foram excluídos da universidade, garantindo mais igualdade econômica, política, cultural e social. Pode-se dizer que as cotas são uma forma de tornar a universidade mais plural, atendendo diferentes segmentos da sociedade, não fazendo distinção de pessoas, propiciando aos excluídos historicamente a oportunidade de graduação em um curso superior. Mas é importante lembrar que as cotas representam uma medida paliativa para 
reparar, dar condições e oportunidades de acesso à Educação Superior. Sua aplicabilidade requer atitudes que se baseiam nos princípios democráticos, como, a igualdade de oportunidades e o reconhecimento.

Assim sendo, de acordo com os dados obtidos nesta pesquisa, podemos dizer que através das políticas de cotas e das ações desenvolvidas pelo programa UFG/Inclui, a UFG Regional Goiânia vem ampliando o seu acesso, garantindo um percentual maior de alunos nos cursos. Nota-se uma maior representatividade dos estudantes de escola pública dentro da instituição, bem como negros; quilombolas e de indígenas. Porém, os dados mostram que a quantidade de alunos das licenciaturas que concluem a graduação é relativamente menor do que os que ingressam. A evasão ocorre devido a vários motivos, como reprovações, dificuldade de se conciliar trabalho e estudo, baixo desempenho nas disciplinas, problemas financeiros, falta de tempo para os estudos, não identificação com o curso e o não reconhecimento das potencialidades e singularidades.

Alguns cursos apresentam um índice de desistência maior, como Física, Geografia, Ciências Biológicas, Pedagogia, Química e outros. Diante disso, é fundamental que a instituição, juntamente como o programa UFG/Inclui, reflita sobre as ações efetivadas para diminuir o índice de evasão e acabar com a exclusão e a discriminação. Acreditamos que as universidades tenham como tarefa, ao aderirem às ações afirmativas, revisar as relações e práticas pedagógicas, as metas e as ações previstas.

Certificamos, ainda, que a entrada de alunos do gênero feminino é mais expressivo quando comparada ao gênero masculino. Isso ocorre devido às conquistas que as mulheres vêm adquirindo no decorrer dos anos no espaço social, através das lutas pela garantia de igualdade de seus direitos. Mas ainda há muito a ser feito em relação a esse fato, uma vez que a discriminação perdura em nossa sociedade.

Considerando a questão da evasão, apreendemos que as dificuldades dos alunos no decorrer de sua formação estão relacionadas à conciliação trabalho e estudo, a dificuldades na aprendizagem, a condições financeiras (a maioria dos estudantes que procura o sistema de cotas tem uma renda familiar mensal menor comparado aos estudantes que procuram o sistema universal) e transporte, sendo esses, muitas vezes, o motivo da inativação. $\mathrm{O}$ acesso à universidade é fundamental para os excluídos deste sistema, mas devemos considerar que a inserção não é garantia sucesso profissional. Pois como já foi abordado há um índice considerável de evasão nos cursos de licenciaturas, mesmo com a criação do programa UFG/Inclui. 
Nas respostas dos estudantes, mesmo as relações interpessoais dentro da universidade se dando de forma harmoniosa e respeitosa, foi possível identificar a ocorrência de discriminação dentro dos cursos, sendo essa, na maioria das vezes, de forma velada. Devemos frisar que a UFG não divulga os nomes dos alunos do sistema de cotas, trabalhando de forma sigilosa. No entanto, alguns alunos rotulam os estudantes negros e os que apresentam menor condição financeira como provenientes das cotas. Bem sabemos que as práticas discriminatórias podem ser um dos fatores que provoque o baixo desenvolvimento dos educandos, impedindo-os de concluir o curso. Nesse sentido, a instituição precisa buscar formas de eliminar atos discriminatórios existentes, promovendo debates, palestras e disciplinas que abarquem sobre o assunto, entre outros.

A Resolução Consuni/UFG (2008) prevê a garantia da permanência por meio do programa UFG/Inclui, mas é preciso discutir e trabalhar melhor essa proposta. Para isso, é necessário que haja uma avaliação dos objetivos para se verificar se estes estão sendo atendidos e se os resultados são suficientes em relação quanto ao acesso e permanência dos estudantes oriundos das cotas. Vimos que a instituição vem avaliando o programa por meio dos seminários UFG/Inclui, tendo este a finalidade de analisar e discutir o programa, trazendo dados referentes ao ingresso, permanência e também ao desempenho dos estudantes. No entanto, nem todos os cursos participam do seminário.

Nota-se que se faz necessário uma avaliação mais aprofundada, para verificar se as ações de assistência estão de acordo com a realidade dos alunos. Acreditamos que é preciso dar mais voz aos estudantes para que expressem suas necessidades e dificuldades durante o seu processo formativo na universidade. Com os dados do questionário, observamos que os estudantes defendem outras políticas de assistência além das já efetivadas no programa UFG/Inclui, como bolsa trabalho, ações voltadas para o ensino e pesquisa, transporte, e outros.

O outro fator que a universidade deve considerar é a questão da divulgação de suas ações, pois muitos alunos não têm acesso às informações sobre o programa UFG/Inclui, ficando, assim, desprovidos de qualquer chance de obterem os benefícios. Verificamos que os alunos que não obtiveram informações sobre o programa são os que não foram contemplados com nenhuma assistência estudantil. Desse modo, entendemos que não adianta a instituição promover vários mecanismos de assistência se não divulgar ao público alvo, já que sem conhecimento de tais propostas, não se pode usufruí-las.

Através do programa UFG/Inclui a universidade vem buscando reconhecer as singularidades dos estudantes que entram por meio de cotas, propondo ações de assistência 
que permita o individuo construir a sua identidade e autonomia no decorrer do seu processo acadêmico, através da forma do direito e da solidariedade. Sendo essas esferas fundamentais para a autorrealização dos estudantes nos cursos e na profissão. .

Ao ser reconhecido o estudante se sentirá como indivíduo de igual valor na sociedade, sendo as suas habilidades e capacidades valorizadas. Podemos dizer que, a partir do momento em que a universidade reconhece a particularidade dos alunos das licenciaturas e possibilita uma formação que permita o desenvolvimento da sua auto-estima e o desenvolvimento da sua identidade na área estará permitindo a sua autorrealização na profissão. Portanto, a universidade precisa empenhar-se num processo educativo que garanta o "reconhecimento" de que fala Honneth. Pois assim o futuro: "professor não será mais um julgador, e nem uma presença ausente, e, sim coparticipante do conhecimento do aluno, desde que o seu saber tenha impregnância no saber do outro." Devido a isso os educadores: "que pautam a sua conduta inspirados no horizonte da estima e da consideração, tendem a ser mais bem sucedidos em sua prática diária” (TREVISAN, 2014, p. 129).

No entanto, o estudo evidenciou, por meio dos dados dos questionários respondidos pelos coordenadores e pelos alunos oriundos do sistema de cotas, que a UFG tem condições de melhorar o seu papel no que se refere ao reconhecimento das particularidades e singularidades dos estudantes. Dessa forma, acreditamos que a instituição terá mais facilidade para promover políticas de assistência que realmente atendam as necessidades dos alunos, podendo colaborar mais na realização profissional docente. É necessário, além de dar acesso, permitir que eles se sintam integrados e valorizados na instituição. A universidade não poderá repetir a posição de falso reconhecimento da sociedade. Se os futuros professores não forem reconhecidos no seu processo formativo na universidade, é provável que eles terão dificuldades de reconhecer o outro no exercício da sua profissão.

Esta pesquisa não esgota as possibilidades de análise e reflexão sobre tal temática. Isso porque, esperamos que outros estudiosos deem continuidade ao estudo. Diante do que foi exposto, acreditamos que há vários pontos ainda a serem discutidos, por exemplo, como compreender as reconfigurações decorrentes das políticas de cotas nos currículos dos cursos de licenciatura; como em se dando as práticas dos professores no sentido de garantir o reconhecimento das particularidades e diferenças dos estudantes do sistema de cotas. 


\section{REFERÊNCIAS}

BRASIL, Constituição Federal de 1988.

. Projeto de Lei No 73-C de 1999.

. Lei de Diretrizes e Bases de 1996.

2002.

. Decreto 4.228 Programa Nacional de Ações Afirmativas e dá outras providências.

. Lei 10.558 Programa diversidade na universidade. 2002

. Projeto de Lei 1.332 de 1983. Disponível em:

http://www.abdias.com.br/atuacao_parlamentar/atuacao_parlamentar.htm. Acessado em 30/01/2014.

. Resolução CONSUNI/ UFG- Conselho Universitário da Universidade Federal de Goiás No 20/2008.

Ministério da Educação. Decreto 4.228 Programa Nacional de Assistência Estudantil para as Instituições de Educação Superior Públicas Estaduais -Pnaest 2010. Disponível em: http://portal.mec.gov.br/index.php?option=com_content\&view=article\&id=16197:instituicoes -terao-recursos-para-assistencia-estudantil\&catid=212\&Itemid=86. Acessado em 29/07/2013.

. Ministério da Educação. Lei 12.711de 2012.

Site:http://portal.mec.gov.br/cotas/sobre-sistema.html. Acessado dia 17/05/2013.

Decreto 1.904/96. Programa Nacional de Direitos Humanos, 1996.

http://www.direitoshumanos.usp.br/index.php/Direitos-Humanos-no-Brasil/i-programanacional-de-direitos-humanos-pndh-1996.html. Acessado dia 16/07/2013.

. III Conferência Mundial de Combate ao Racismo, Xenofobia e Intolerância

Correlata: Declaração de Durban e Plano de Ação. 2001. Disponível em:

http://www.unifem.org.br/sites/700/710/00001626.pdf. Acessado em05/08/2013.

Instituto Nacional Anísio Teixeira, 2014.

. Lei 10.639 de Janeiro de 2003. Disponível em:

http://www010.dataprev.gov.br/sislex/paginas/42/2003/10639.htm Acessado dia 11/07/2014.

. Ministério da Educação - Reuni decreto Presencial no 6.096, 2007.

. Sistema eletrônico do serviço de informação ao cidadão, 2014.

Lei 11.096/052005.

2013http://prouniportal.mec.gov.br/index.php?option=com_content\&view=article\&id=124\&I temid=140. . Acessado dia 26/05/2013. 
Ministério da Educação/ Universidade Federal de Goiás. Estatuto aprovado dia 29 de novembro de 2013. Disponível emhttp://www.ufg.br/uploads/1/original_ESTATUTO_2014.pdf. Acessado dia 21/07/2013 .

BARROS, Clarissa Fernandes do Rêgo. As ações afirmativas na UERJ: trajetórias sociais e perspectivas dos estudantes cotistas no desafio do acesso à universidade. XIII encontro nacional de pesquisa em serviço social, 2009. Disponível em:

file:///C:/Users/kelly/Downloads/UNKNOWN_PARAMETER_VALUE.pdf. Acessado em $19 / 08 / 2014$.

BRZEZINSKI, Iria. Profissão Professor: identidade e profissionalização docente. Brasília: Plano Editora, 2002.

Políticas contemporâneas de formação de professores para os anos inicias do ensino fundamental. Educ. soc., Campinas, v. 29, n. 105, p. 1139-1166. set./dez.2008.

CIRQUEIRA, Diogo Marçal; Gonçalves, Carlianne Paiva; RATTS, Alex. As marcas da travessia: o processo de implementação de ações afirmativas e cotas na universidade Federal de Goiás. In: Cotas nas universidades: análises dos processos de decisão (org) Jocélio Teles dos Santos, organizador. - Salvador: CEAO, 2012. Disponível: http://www.redeacaoafirmativa.ceao.ufba.br/uploads/ceao_livro_2012_JTSantos.pdf. Acessado em 19/08/2013.

CORDEIRO, Maria José de Jesus Alves. Ações Afirmativas: políticas de acesso e permanência nas instituições de ensino superior. Revista de Ciências Sociais. Política e trabalho n. 33 p. 97-115 outubro de 2010. Disponível em:

http://periodicos.ufpb.br/ojs/index.php/politicaetrabalho/article/view/9035/4750. Acessado em 07/08/2013.

DEVECHI, Catia Piccolo Viero; TREVISAN, Amarildo. Sobre a proximidade do senso comum das pesquisas qualitativas em educação: positividade ou simples decadência? Revista Brasileira de Educação. v. 15, n. 43, 2010, p. 148-201. Disponível em <http://www.scielo.br/pdf/rbedu/v15n43/a10v15n43.pdf>. Acesso em23/05/2013.

ESTEVE, J. M. O mal-estar docente - a sala de aula e a saúde dos professores. Trad. Durley de Carvalho Cavicchia. Bauru: Edusc, 1999.

FUHRMANN, Nadia. Luta por reconhecimento: reflexões sobre a teoria de Axel Honneth e as Origens dos conflitos sociais. Barbarói, Santa Cruz do Sul, n.38, p.<79-96>, jan./jun. 2013.

GOMES, Joaquim B. Barbosa. A recepção do instituto da ação afirmativa pelo Direito Constitucional brasileiro. Brasília a. 38 n. 151 jul./set. 2001.

GONÇALVES, Jéssica. A UFG adere integralmente ao Sisu a partir do vestibular de 2015/1. Acessória de Comunicação. 2014 Disponível em: http://ascom.ufg.br/pages/69756-ufg-adereintegralmente-ao-sisu-a-partir-do-vestibular-2015-1. Acessado em 18/09/2014.

HABERMAS, Jürgen. Dialética e hermenêutica: Para a crítica da hermenêutica de Gadamer. Porto Alegre: L\&PM, 1987.

HONNETH, Axel . Luta por reconhecimento: a gramática moral dos conflitos sociais. São Paulo. Ed.34, 2003. 
IMBERNÓN, Francisco. Formação Docente e Profissional: formar para a mudança e a incerteza. 9 ed. São Paulo: Cortez, 2011.

NÓVOA, Antônio. Formação de professores e a profissão docente. In: (org). Os professores e sua formação. Portugal: Porto, 1992.

.Os professores e as histórias da sua vida. In: NÓVOA, Antônio (org). Vidas de professores. Portugal: Porto, 1992.

JESUS, Saul Neves de. Perspectivas para o bem-estar docente: uma lição de síntese. Porto: Asa, 2002.

LÁZARO, André, CALMON, Claúdia, LIMA, Publicações Dom Quixote, 1999. Silvio; OLIVEIRA, Leidiane. Inclusão na educação superior. In: Ações Afirmativas e Inclusão: um balanço. Cadernos do GEA N. 2 jul-dez 2012.

MARCONI, M. A.; LAKATOS, E. M. Técnicas de Pesquisa. 4. ed. São Paulo: Atlas, 2008.

MOURA, Deyse. Diferença entre número de ingressantes e concluintes em licenciatura no Brasil ainda é expressiva. Revista Escola. Outubro 15,2013. Disponível em http://www.sinasefern.org.br/diferenca-entre-numero-de-ingressantes-e-concluintes-emlicenciatura-no-brasil-ainda-e-expressiva/. acessado em 27/08/2014.

MUNANGA, Kabengele. Política de ação afirmativa em benefício da população negra no Brasil: Um ponto de vista em defesa das cotas. Revista Sociedade e Cultura v. 4, n. 2, jul./dez. 2001, p. 31-43.

PEREIRA, Júlio Emílio Diniz. O ovo ou a galinha: a crise da profissão docente e a aparente falta de perspectiva para a educação brasileira. R. Bras. Est. Pedag., Brasília, v. 92, n 230, p. 34-51, jan/abr. 2011.

QUEIROZ, Delcele Mascarenhas; SANTOS, Jocélio Teles. Sistema de cotas: um debate dos dados à manutenção de privilégios e de poder. Educ. Soc., Campinas, vol. 27, n. 96 Especial, p. 717-737, out. 2006.

QUEIROZ, Edna M. Oliveira; FARIA, Gina G. Guimarães; PEREIRA, Mariana Cunha; ANDRADE, Tânia Mírian; GABASSA Vanessa. Seminário Programa UFG/Inclui. Ações Afirmativas: avanços e desafios, 2013. Disponível em: http://www.prograd.ufg.br. Acessado em 10/11/2013.

SANTOS, Maria Cristina Elyote Marques; SANTOS, Paulo César Marques de Andrade. Universidade e Política de cotas: o acesso e a permanência do cotista na Universidade do Estado da Bahia. XI Congresso Luso Afro Brasileiro de Ciências Sociais. Universidade Federal da Bahia- Salvador, 2011. Site: http://www.xiconlab.eventos.dype.com.br/resources/anais/3/1307670542_ARQUIVO_UNIV ERSIDADEEPOLITICADECOTAS.pdf. Acessado dia 09/05/2013.

SILVÉRIO, Valter Roberto. Ações afirmativa e diversidade étnico-racial. In: BRASIL/Ministério da Educação. Ações afirmativas e combate a discriminação na América. 2005.

TREVISAN, Amarildo Luiz. Reconhecimento do outro: teorias filosóficas e formação docente. Campinas, SP: Mercado de Letras, 2014. 
UNIVERSIDADE FEDERAL DE GOIÁS. Centro de Seleção, 2014.

Prograd-Pró-Reitoria de Graduação, 2014

. Seminário Programa UFG/Inclui. Ações Afirmativas: avanços e desafios, 2011. Disponível em: Site: http://www.prograd.ufg.br. Acessado em 10/05/2013.

. Universidade Federal de Goiás. Plano de Desenvolvimento Institucional, 2011/15. Goiânia, 2014.

. Seminário Programa UFG/Inclui. Ações Afirmativas: avanços e desafios, 2013.

Disponível em: http://www.prograd.ufg.br. Acessado em 10/11/2013.

Edital $n^{\circ}$ 031/20013 processo seletivo 2013-2. Disponível:

http://www.vestibular.ufg.br/2013/ps2013_2/sistema/edital/EDITAL_2013_2.pdf. Acessado dia 11/05/2013.

Programa Conexões de Saberes 2008. Disponível:

http://www.ufg.br/uploads/files/Conexoes_saberes_Edital_2008.pdf. Acessado em 19/09/2013.

. Pró-Reitoria de Graduação 2013. Disponível em.

http://www.prograd.ufg.br/uploads/90/original_INGRESSANTES_ACAO_AFIRMATIVA.p df. Acessado em 07/06/2013.

Revista UFG. Goiânia, $\mathrm{n}^{\circ}$ 1, março de 2008. Disponível em:

http://www.ascom.ufg.br/uploads/84/original_Revista_UFG_Afirmativa_1_low.pdf. Acessado em07/06/2013.

Assessoria de Comunicação. Confira o que há de novo no vestibular da UFG para 2013.Disponível em: http://www.ufg.br/page.php?noticia=9184. Acessado em 13/06/2012.

MARTINS, Michele. Câmara de Graduação da UFG aprova ampliação das vagas destinadas ao Sisu, 2013. Disponível em: http://www.ufg.br/page.php?noticia=10245. Acessado em 27/08/2013.

Programa conexões de saberes-Edital PROEC $N^{\circ}$ 002/2008 . Disponível em:http://webcache.googleusercontent.com/search?q=cache:95Dei6sNFeYJ:www.ufg.br/uploads/ files/Conexoes_saberes_Edital_2008.pdf $+\& c d=1 \& \mathrm{hl}=\mathrm{pt}-\mathrm{BR} \& \mathrm{ct}=\mathrm{clnk} \& \mathrm{gl}=\mathrm{br}$. Acessado em 05/11/2013. 20/2008.

Resolução CONSUNI- Conselho Universitário da Universidade Federal de Goiás No

PROGRAD- Programa de Educação Tutorial, 2013. Disponível http://prograd.ufg.br/pages/16213-pet. Acessado dia 16/07/2014.

. Resolução Consuni no 20 de 2010. Altera o Anexo da Resolução Consuni $n^{\circ}$ 29/2008, que cria o Programa "UFGInclui" na UFG, para inclusão da reserva de vagas do Curso de Letras - Libras para candidatos surdos. Goiânia: UFG, 2010. 
VELLOSO, Jacques. Cotistas e não-cotistas: rendimento de alunos da Universidade de Brasília. Caderno de Pesquisa. V. 39 n. 137, São Paulo, agosto de 2009.

ZONINSEIN, Jonas. Minorias étnicas e a economia política do desenvolvimento: um novo papel para as universidades públicas como gerenciadoras da ação afirmativa no Brasil? In: JUNIOR ; ZONINSEIN (org.) Ação afirmativa e universidade: experiências nacionais comparadas Brasília. Ed: Universidade de Brasília, 2006. 


\section{APÊNDICE A - INSTRUMENTAL QUESTIONÁRIO}

\section{Questionário coordenador}

Carta de apresentação

Prezados (as) coordenadores (as)

Meu nome é Kelly Coelho Costa Barreto, mestranda do Programa de Pós-graduação em Educação da Universidade de Brasília. Sob Orientação da professora Dra. Catia Piccolo Viero Devechi, estou desenvolvendo uma pesquisa sobre a implementação das políticas públicas de inclusão nos cursos de licenciatura da UFG, buscando conhecer as estratégias utilizadas para garantir a permanência do aluno cotista nos cursos. Tal pesquisa faz parte de um projeto interinstitucional (UnB, FURG e UFSM) que busca compreender de que maneira os cursos de licenciaturas das universidades públicas federais do Brasil estão trabalhando na implementação de uma política afirmativa, que aposta na permanência do estudante cotista na instituição. Nesse sentido, gostaria de convidá-los a participarem dessa pesquisa, respondendo algumas questões que serão fundamentais à compreensão da temática. Os dados obtidos na pesquisa serão disponibilizados a todos os respondentes do questionário, sendo as informações pessoais asseguradas pelo anonimato. Desde já, agradeço a disponibilidade e para quaisquer esclarecimentos, por favor, entre em contato com Kelly Coelho Costa Barreto

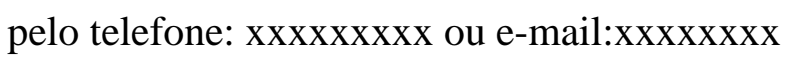

Sem mais para o momento, colocamo-nos à disposição.

Perguntas

1. Nome do coordenador

2. Formação Inicial. Qual? (licenciatura ou bacharelado)

3. Pós-graduação

Especialização $\bigcirc$ Mestrado $\bigcirc$ Doutorado

4. Em qual área? 
5. Qual curso você coordena?

6. Você é a favor das cotas?

C Sim

C Não

7. Há formas de tratamento diferenciado em relação aos cotistas no curso?

C Sim

C Não

8. Quais são essas formas de tratamento?

9. A evasão dos alunos cotistas no curso é:

(C) Alta

C Baixa

C Regular

Inexistente

10. As evasões são recorrentes a que fatores:

Se considerar necessário, marque mais de uma alternativa.

$\ulcorner$ O baixo desempenho nas disciplinas

$\ulcorner$ Reprovações

$\lceil$ A dificuldade de conciliar trabalho e estudo

ᄃ Não identificação com área do curso

Г Falta de tempo para os estudos

$\ulcorner$ Problemas financeiros

$\ulcorner$ Dificuldade de relacionamento com os colegas

$\ulcorner$ Falta de reconhecimento da sua singularidade e diferença pelos colegas

$\ulcorner$ Falta de reconhecimento da sua singularidade e diferença pelos professores

Г Outra (Por favor, especifique)

11. Como se dá a relação dos alunos cotistas e não cotistas:

C Harmoniosa

C Preconceituosa

C Excludente

C Respeitosa 
12. Que tipo de alterações foram realizadas no currículo do curso para atender aos alunos cotistas?

13. Quais são as dificuldades do curso no acolhimento dos alunos cotistas? Se considerar necessário, marque mais de uma alternativa.

$\ulcorner$ Estrutura física

$\Gamma \quad$ Falta de recursos

$\ulcorner$ Diversidade dos alunos

$\ulcorner$ O baixo desempenho dos alunos cotistas

$\ulcorner$ A formação dos professores

$\lceil$ O preconceito da comunidade acadêmica em relação aos cotistas

$\ulcorner$ Outra (Por favor especifique)

14. Como é o desempenho do aluno cotista no curso?

Г Ótimo

Г Bom

$\lceil$ Regular

$\ulcorner$ Insuficiente

15. Como o curso vem tentando garantir a permanência dos alunos cotistas? Se considerar necessário, marque mais de uma alternativa.

$\ulcorner\quad$ Nivelamento dos conhecimentos básicos

$\ulcorner$ Bolsa de estudo

Г Bolsa permanência

$\ulcorner$ Apoio pedagógico

$\ulcorner$ Apoio psicológico

$\ulcorner$ Outro (Por favor especifique)

16. Como o curso vem se preparando para atender um maior número de cotistas a partir de 2013? 


\section{APÊNDICE B - INSTRUMENTAL QUESTIONÁRIO}

\section{Questionário alunos}

Carta de apresentação

Meu nome é Kelly Coelho Costa Barreto, mestranda do Programa de Pós-graduação em Educação da Universidade de Brasília. Sob Orientação da professora Dra. Catia Piccolo Viero Devechi, estou desenvolvendo uma pesquisa sobre a implementação das políticas públicas de inclusão nos cursos de licenciatura da UFG, buscando compreender as estratégias de reconhecimento promovidas pela UFG Regional Goiânia. Pretendemos com a pesquisa contribuir com indicadores que ofereçam à universidade e à sociedade civil organizada a possibilidade de definir estratégias de reconhecimento das diferenças, garantindo o monitoramento das políticas de inclusão. É muito importante a sua participação para que a pesquisa seja realizada.

Sem mais para o momento, colocamo-nos à disposição.

\section{Perguntas}

1- Curso matriculado

2- Você conhece as ações desenvolvidas pelo programa UFG/Inclui? Sim ( ) Não ( )

3- Qual é a avaliação que você faz do programa UFG/Inclui?

4- Há divulgação das ações de assistência desenvolvida na UFG? ( ) $\operatorname{Sim}$ ( ) Não

5- Você foi contemplado com alguma ação de assistência estudantil na UFG? Qual?

6- Para você, as ações de assistência estudantil da UFG abarcam todos os alunos da Universidade?

7- Você se sente acolhido pelas ações desenvolvida na UFG?

8- Você percebe a sua individualidade reconhecida na universidade? Sim ( ) Não ( )

9- Como percebe o o reconhecimento das diferenças dentro da UFG?

10- Para você, o projeto UFG/Inclui influencia no acolhimento das diferenças dentro da universidade?

11- Para você, as ações de assistência desenvolvidas na UFG garante o desenvolvimento acadêmico do aluno? Justifique sua resposta.

( ) $\operatorname{Sim}$ ( ) Não

12- Do seu ponto de vista que ações de assistência estudantil a universidade deve oferecer para que todos os alunos sejam reconhecidos?

13- Como é a sua relação com os colegas?
( ) Harmoniosa
( ) Preconceituosa
( ) Excludente 
( ) Respeitosa

14- Como é a sua relação com os professores?
( ) Harmoniosa
( ) Preconceituosa
( ) Excludente
( ) Respeitosa

15- Você tem dificuldade de se reconhecer como aluno proveniente do sistema de cotas? Justifique.

( ) $\operatorname{Sim}$ ( ) Não

16- Alguma vez você foi discriminado por ser aluno oriundo do sistema de cotas? Justifique.

( ) $\operatorname{Sim}$ ( ) Não

17- Você se sente realizado no curso?

Sim ( ) Não ( )

18- Pretende atuar como professor?

19- Quais as dificuldades encontradas no seu processo de formação dentro da UFG?

20- Quais ações pedagógicas a UFG deve proporcionar para que o aluno tenha um bom desenvolvimento no curso?

21- O que você pretende fazer em relação às políticas de inclusão quando estiver na Escola Básica? 


\section{APÊNDICE C - TERMO DE CONSENTIMENTO LIVRE E ESCLARECIDO}

\section{Termo de Consentimento Livre e Esclarecido- Coordenadores}

Você está sendo convidado a participar da pesquisa As cotas nos cursos de licenciaturas presenciais da Universidade Federal de Goiás Regional Goiânia: a questão do reconhecimento, de responsabilidade de Kelly Coelho Costa Barreto, aluno(a) de mestrado da Universidade de Brasília. O objetivo desta pesquisa é compreender as estratégias de reconhecimento promovidas pela UFG Regional Goiânia e pelos cursos de licenciatura. Assim, gostaria de consultá-lo (a) sobre seu interesse e disponibilidade de cooperar com a pesquisa.

Você receberá todos os esclarecimentos necessários antes, durante e após a finalização da pesquisa, e lhe asseguro que o seu nome não será divulgado, sendo mantido o mais rigoroso sigilo mediante a omissão total de informações que permitam identificá-lo(a).

A coleta de dados será realizada por meio grupo focal. É para estes procedimentos que você está sendo convidado a participar. Sua participação na pesquisa não implica nenhum risco.

Espera-se com esta pesquisa contribuir com indicadores que ofereçam à universidade e à sociedade civil organizada a possibilidade de definir estratégias de reconhecimento das diferenças e garantindo o monitoramento das políticas de inclusão.

Sua participação é voluntária e livre de qualquer remuneração ou benefício. Você é livre para recusar-se a participar, retirar seu consentimento ou interromper sua participação a qualquer momento. A recusa em participar não irá acarretar qualquer penalidade ou perda de benefícios.

Se você tiver qualquer dúvida em relação à pesquisa, você pode me contatar pelo

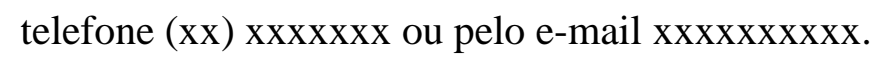

A equipe de pesquisa garante que os resultados do estudo serão devolvidos aos participantes por meio de e-mail, podendo ser publicados posteriormente na comunidade científica.

Este documento foi elaborado em duas vias, uma ficará com o (a) pesquisador(a) responsável pela pesquisa e a outra com o senhor(a). 
Brasília, de de

Termo de Consentimento Livre e Esclarecido- Alunos

Você está sendo convidado a participar da pesquisa As cotas nos cursos de licenciaturas presenciais da Universidade Federal de Goiás Regional Goiânia: a questão do reconhecimento, de responsabilidade de Kelly Coelho Costa Barreto, aluno(a) de mestrado da Universidade de Brasília. O objetivo desta pesquisa é compreender as estratégias de reconhecimento promovidas pela UFG Regional Goiânia e pelos cursos de licenciatura. Assim, gostaria de consultá-lo(a) sobre seu interesse e disponibilidade de cooperar com a pesquisa. Você receberá todos os esclarecimentos necessários antes, durante e após a finalização da pesquisa, e lhe asseguro que o seu nome não será divulgado, sendo mantido o mais rigoroso sigilo mediante a omissão total de informações que permitam identificá-lo(a).

Você é livre para recusar-se a participar, retirar seu consentimento ou interromper sua participação a qualquer momento. A recusa em participar não irá acarretar qualquer penalidade ou perda de benefícios. Se você tiver qualquer dúvida em relação à pesquisa, você pode me contatar pelo telefone $(\mathrm{xx}) \operatorname{xxxxxx}$ ou pelo e-mail xxxxxx. A equipe de pesquisa garante que os resultados do estudo serão devolvidos aos participantes por meio de e-mail, podendo ser publicados posteriormente na comunidade científica.

Caso você aceite participar da pesquisa clique na opção seguinte. 